\title{
EFEITO DE INTENSIDADES DE PASTEJO SOBRE O ÍNDICE DE ÁREA FOLIAR, INTERCEPTAÇÃO LUMINOSA E ACÚMULO DE FORRAGEM EM PASTAGENS DE Cynodon spp.
}

\section{JAILSON LARA FAGUNDES}

\author{
Dissertação apresentada à Escola Superior \\ de Agricultura "Luiz de Queiroz", \\ Universidade de São Paulo, para obtenção \\ do título de Mestre em Agronomia, Área de \\ concentração: Ciência Animal e Pastagens.
}

\author{
PIRACICAB A \\ Estado de São Paulo - Brasil \\ Fevereiro - 1999
}




\section{EFEITO DE INTENSIDADES DE PASTEJO SOBRE O ÍNDICE DE ÁREA FOLIAR, INTERCEPTAÇÃO LUMINOSA E ACÚMULO DE FORRAGEM EM PASTAGENS DE Cynodon spp.}

Jailson Lara Fagundes

ENGENHEIRO AGRÔNOMO

Orientador: Prof. Dr. SILA CARNEIRO DA SILVA

Dissertação apresentada à Escola Superior de Agricultura "Luiz de Queiroz", Universidade de São Paulo, para obtenção do título de Mestre em Agronomia, Área de concentração: Ciência Animal e Pastagens.

$P \mid R A C I C A B A$

Estado de São Paulo - Brasil

Fevereiro - 1999 
Dados Internacionais de Catalogação na Publicação (CIP)

DIVISÃO DE BIBLIOTECA E DOCUMENTAÇÃO - Campos "Luiz de Queiroz"/USP

\section{Fagundes, Jailson Lara}

Efeito de intensidades de pastejo sobre o índice de área foliar, interceptação luminosa e acúmulo de forragem em pastagens de Cynodon spp. / Jailson Lara Fagundes. -- Piracicaba, 1999.

69 p. : il.

Dissertação (mestrado) - - Escola Superior de Agricultura Luiz de Queiroz, 1998. Bibliografia.

1.Efeito da luz 2.Folha 3. Forragem 4.Pastagem 5. Pastejo 6. Variedade I. Título

CDD 636.08422

"Permitida a cópia total ou parcial deste documento, desde que citada a fonte - O autor" 


\section{DEDICO}

Aos meus pais

Jair Vargas Fagundes e Mari Terezinha Lara Fagundes

À minha irmã Josiane Lara Fagundes

À minha namorada Carla Rossi e aos meus demais familiares

MINHA GRATIDÃO E HOMENAGEM

\section{OFEREÇO}

Aos amigos

Silvio Luiz Pereira da Silva

Sergio Pereira da Silva (In memorian),

Natal Bernardes Bem (In memorian). 
Não basta que pura e justa seja a nossa causa

É necessário que a justiça e a pureza existam dentro de nós.

(Agostinho Neto)

Que todos os viajantes encontrem felicidade por onde quer que vão e, sem esforço realizem o que se propuseram a fazer, e ao retornarem, são e salvos, que sejam recebidos com alegria por seus parentes.

(DALAI LAMA KUN-DUN) 


\section{AGRADECIMENTOS}

Ao Prof. Dr. Sila Carneiro da Silva e ao Prof. Dr. Carlos Guilherme Silveira Pedreira pela orientação inestimável, pela amizade, pela atenção e pela paciência prestada na realização deste trabalho.

Ao Prof. Dr. Ricardo Ferraz de Oliveira pela colaboração na realização deste trabalho.

A todos os professores do Departamento de Produção Animal da

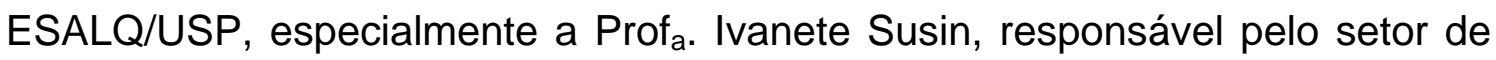
Ovinocultura pela concessão dos animais utilizados no ensaio.

Aos estagiários e pós-graduandos do Grupo de Estudo com Plantas Forrageiras que ajudaram na instalação, condução e análise deste experimento.

A todos os colegas do curso de pós-graduação em Ciências Animal e Pastagens, pelo constante incentivo e pela amizade convivência harmoniosa.

À Casa do Estudante Universitário da UFSM e à Vila Estudantil da ESALQ-USP pelo acolhimento e moradia, os quais proporcionaram-me melhores condições de estudo.

A todos os moradores da Vila Estudantil da pós-graduação ESALQ-USP, especialmente aos colegas Vanderlei Koeffender, Regis Heinrichs, José Gabriel da Silva, Jonas Rushel, Antonio Sampaio, Aderbal Rocha, Evandro Righi e Robinson Andrade com os quais dividi parte de minha vida.

A todos os funcionários do Departamento de Produção Animal pela cooperação e amizade.

À Fundação de Coordenação de Aperfeiçoamento de Pessoal de Nível Superior, CAPES, pela concessão da bolsa de estudo.

À FAPESP pelo financiamento deste projeto.

Às Instituições de Ensino Público que me proporcionaram estudo e que, sem as quais, seria difícil conseguir estudar até o presente momento.

Aos demais colegas, amigos e parentes que me incentivaram, apoiaram e que, de uma forma ou de outra, cooperaram e contribuíram nesta caminhada. 


\section{SUMÁRIO}

\section{PÁGINA}

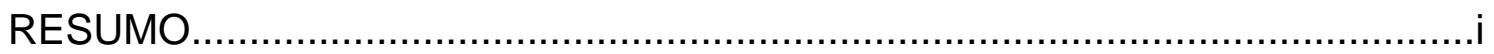

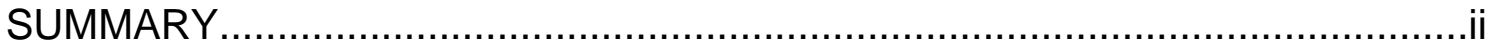

1 INTRODUÇÃO

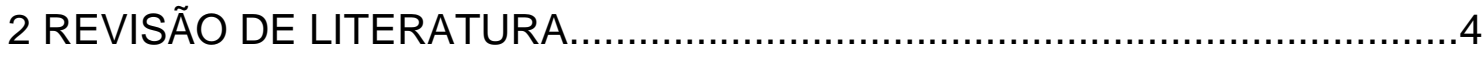

2.1 Gênero Cynodon:Desenvolvimento de cultivares.....................................

2.2 Alguns fatores de produção de plantas forrageiras.....................................

2.2.1 Relações envolvendo a luz em comunidades vegetais.............................5

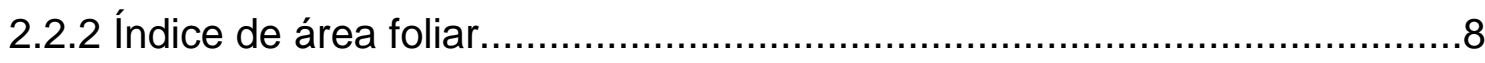

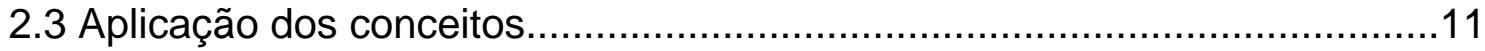

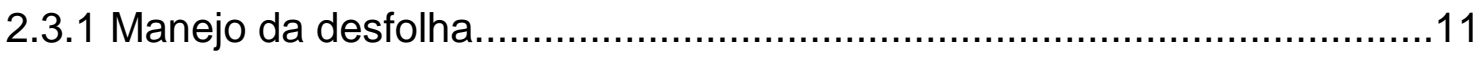

2.3.2 Cynodon spp. em sistemas de produção animal...................................12

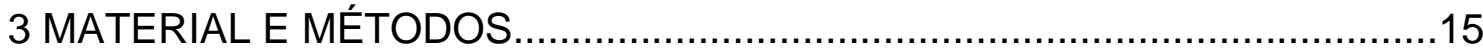

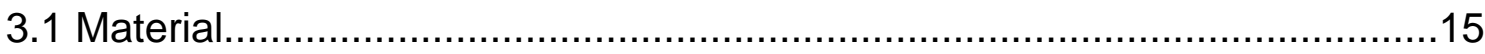

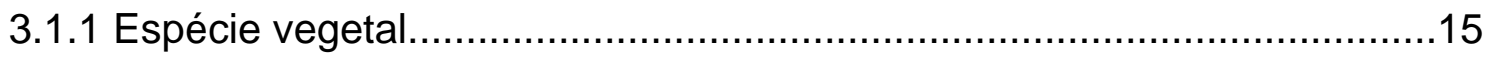

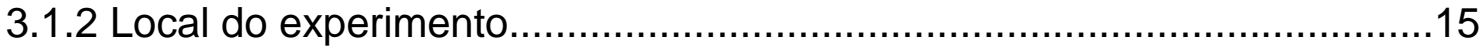

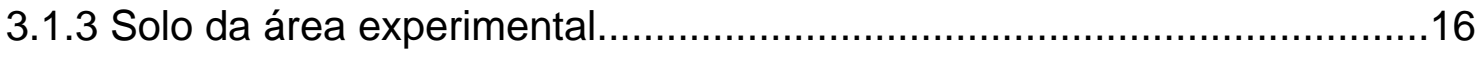

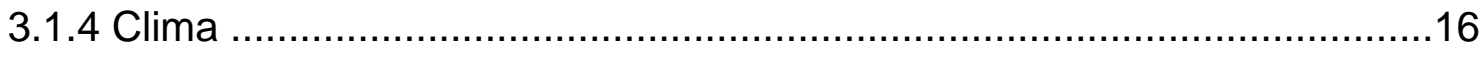

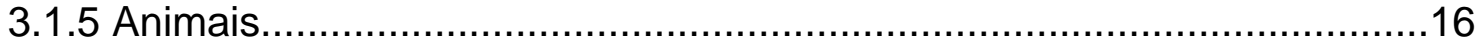

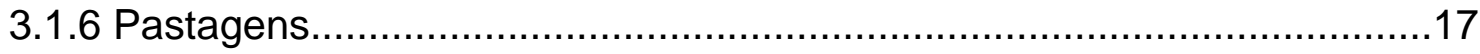

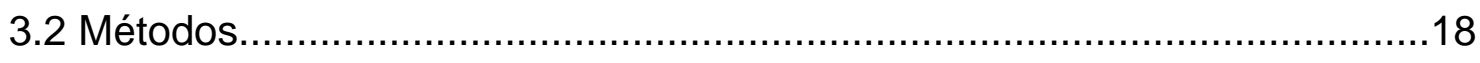

3.2.1 Delineamento experimental e tratamentos......................................18

3.2.2 Instalação e monitoramento das condições experimentais.......................20

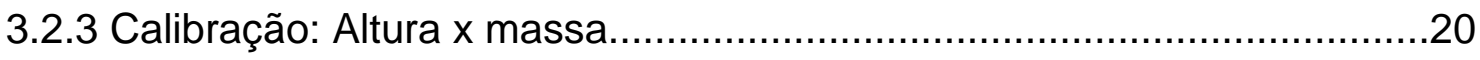

3.2.4 Acúmulo de forragem e composição botânica........................................21

3.2.5 Índice de área foliar e composição botânica/morfológica do pasto..........23

3.2.6 Interceptação luminosa e coeficiente de extinção de luz.........................24 


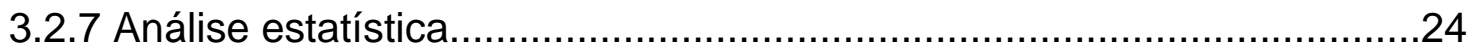

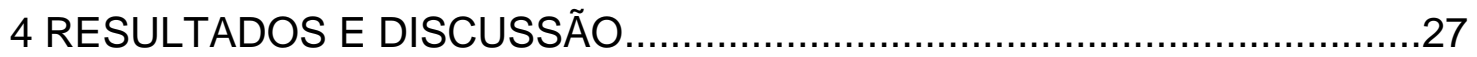

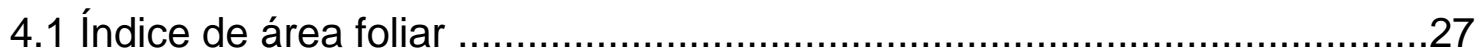

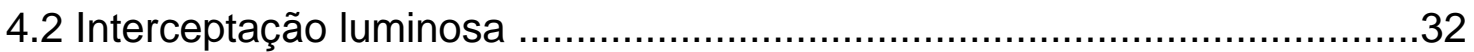

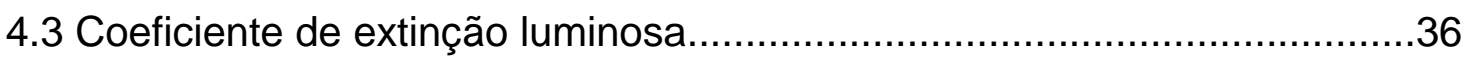

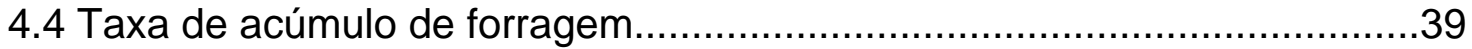

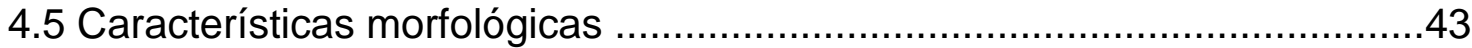

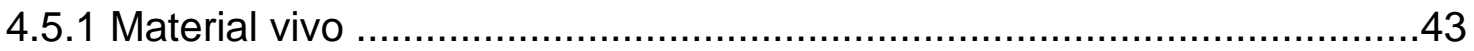

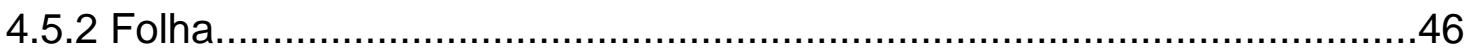

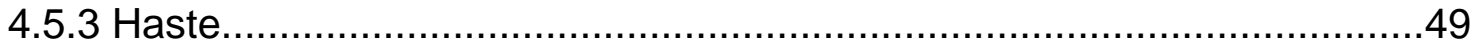

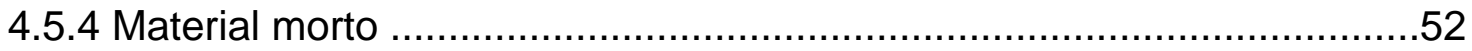

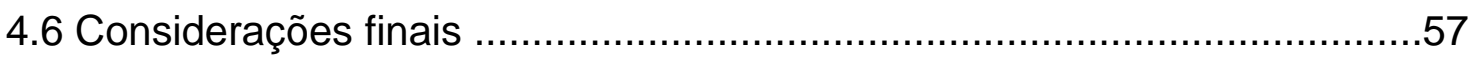

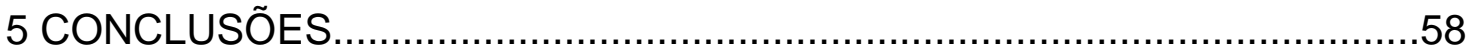

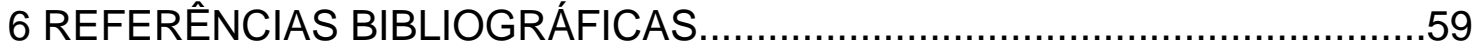




\title{
EFEITO DE INTENSIDADES DE PASTEJO SOBRE O ÍNDICE DE ÁREA FOLIAR, INTERCEPTAÇÃO LUMINOSA E ACÚMULO DE FORRAGEM EM PASTAGENS DE Cynodon spp.
}

\author{
Autor: Jailson Lara Fagundes \\ Orientador: Prof. Dr. Sila Carneiro da Silva
}

\section{RESUMO}

O presente experimento foi conduzido na Unidade Experimental de Plantas Forrageiras (UEPF) em área do Departamento de Produção Animal da ESALQ/USP, em Piracicaba (SP), entre 01/07/98 e 31/12/98. Os tratamentos consistiram de combinações entre três cultivares de Cynodon spp. (Tifton-85, Florakirk e Coastcross) e quatro intensidades de pastejo (5, 10, 15 e $20 \mathrm{~cm}$ ) estabelecidas por ovinos em regime de lotação contínua. O delineamento experimental foi o de blocos completos casualizados com quatro repetições e parcelas sub-divididas, onde na parcela foram alocados os cultivares e na subparcela as intensidades de pastejo. Foram analisadas as seguintes variáveis: índice de área foliar, interceptação luminosa, acúmulo de matéria seca e composição botânica/morfológica dos pastos. Tifton 85 mostrou os maiores valores de IAF para qualquer das intensidades de pastejo estudadas. As taxas de acúmulo de matéria seca foram semelhantes em todos os tratamentos. Tifton 85 apresentou como faixa ótima de uso condições de pasto que variaram de 5 a $15 \mathrm{~cm}$. Já para Florakirk essa faixa foi até $20 \mathrm{~cm}$ e para Coastcross 0 limite superior deve ser maior que $20 \mathrm{~cm}$. De maneira geral os diferentes cultivares devem possuir requerimentos variados de manejo de desfolha quando o objetivo é o uso eficiente da luz e demais fatores de crescimento associado a elevados índices de utilização da forragem produzida. 


\section{GRAZING INTENSITY EFFECT ON LEAF AREA INDEX, LIGHT INTERCEPTION AND HERBAGE ACCUMULATION OF CYNODON SPP. SWARDS}

Author: Jailson Lara Fagundes

Advisor: Prof. Dr. Sila Carneiro da Silva

\section{SUMMARY}

The present trial was carried out at the Pasture and Grazing Studies Unit, Animal Production Department, ESALQ/USP, Piracicaba, State of São Paulo, from July 1 until December 31, 1998. Treatments comprised the possible combinations between three Cynodon spp. cultivars (Tifton-85, Florakirk and Coastcross) and four grazing intensities (5, 10, 15 and $20 \mathrm{~cm}$ ) imposed by sheep under a continuous stocking management. Treatments allocation to experimental units followed a completely randomised block design with four replications and a split-plot arrangement. Grass cultivars were allocated to plots and grazing intensities to sub-plots. The responses studied were leaf area index (LAI), light interception, herbage dry matter accumulation and swards' botanical composition. Tifton-85 showed the highest LAI for any of the grazing intensities used. Herbage dry matter accumulation rates were similar for all treatments. Tifton-85 presented a narrower range of sward conditions for grazing management $(5$ to $15 \mathrm{~cm}$ ) when compared to Florakirk (5 to $20 \mathrm{~cm}$ ) and Coastcross ( 5 to $>20 \mathrm{~cm}$ ). Overall, different grass cultivars presented different grazing management requirements in situations where efficient use of light and high levels of herbage utilisation are targeted. 


\section{INTRODUÇÃO}

A pecuária é uma das principais atividades econômicas do Brasil e se baseia no uso de pastagens nativas ou cultivadas para suprimento de nutrientes para os animais, principalmente ruminantes. Dentre os métodos de utilização das culturas forrageiras, o pastejo é o mais econômico uma vez que a colheita da pastagem é feita pelo próprio animal (Hodgson, 1990).

A baixa produtividade das pastagens é uma das principais causas da baixa competitividade e lucratividade da nossa pecuária em relação a outras explorações econômicas da terra. A reversão deste quadro passa por uma revisão de nossos conceitos sobre pastagens e pela necessidade de intensificação planejada de seu uso. Dentro deste contexto, a exploração de espécies melhoradas, capazes de produzir em quantidade e com qualidade é fundamental, e é neste cenário que os capins do gênero Cynodon têm-se destacado, pois possuem elevado potencial de produção, bom valor nutritivo e grande flexibilidade de uso.

Para explorar todo o potencial dessas gramíneas, visando elevados índices de produção animal, é preciso que se adote técnicas de manejo adequadas a cada espécie ou variedade, tornando-se necessário o conhecimento de seu desempenho agronômico quando submetida ao corte ou pastejo.

Sabe-se que as práticas de manejo da pastagem adotadas em um sistema de produção animal a pasto devem ser determinadas em função das características morfológicas e fisiológicas das plantas para assegurar altas 
produções e persistência das pastagens, sendo que estas características interagem de maneira marcante com as condições de ambiente.

Dentre as características que estão relacionadas com o crescimento e produção das plantas forrageiras destacam-se área foliar, reservas orgânicas, taxa fotossintética e a radiação solar (ambiente luminoso). Uma característica de grande importância para a produtividade de uma planta forrageira é a sua capacidade de recuperação após desfolhas sucessivas, visto que a produtividade é uma função direta do vigor com que ocorre a rebrota, restabelecendo o potencial fotossintético da planta.

No entanto, o maior volume de informações relacionadas com a análise de crescimento de plantas forrageiras em pastagens encontra-se na literatura estrangeira e, portanto, devemos ter certo cuidado no uso dessas informações para orientar práticas de manejo de espécies forrageiras tropicais em nossas condições (Jacques, 1973). Assim, torna-se fundamental que estudos mais detalhados e objetivos sobre a ecofisiologia de plantas forrageiras sob pastejo sejam realizados em nosso meio, de modo a permitir um melhor entendimento do ecossistema das pastagens, e permitir que bases racionais para o manejo sejam estabelecidas. Estes estudos devem levar em consideração aspectos ecofisiológicos das plantas que assegurem sua perenidade, longevidade e produtividade.

Assim, o presente estudo teve por objetivo avaliar o efeito da intensidade de pastejo sobre a interceptação luminosa, índice de área foliar e acúmulo de forragem em pastagens de Cynodon spp. pastejadas por ovinos em regime de lotação contínua. 


\section{REVISÃO DE LITERATURA}

\subsection{Gênero Cynodon: Desenvolvimento de cultivares}

Harlan (1970) apresentou uma classificação do gênero Cynodon, com indicação da distribuição das espécies, estabelecendo a denominação de grupos dentro do gênero, como de grama estrela ('stargrass'), usada para tipos robustos, não rizomatosos, e bermuda ('bermuda grass') para as formas rizomatosas. Harlan et al. (1970) agruparam o gênero em oito espécies de acordo com a sua distribuição geográfica. Destas espécies somente quatro são mais estudadas: Cynodon dactylon, C. nlemfuënsis, C. plectostachyus e C. aethiopicus, encontrando-se distribuídas sobre o leste tropical e às vezes subtropical da África.

Cynodon dactylon (L) Pers. é, entre as espécies, a mais dinâmica e agressiva e tornou-se uma invasora de ambientes com distúrbios, tendo uma distribuição extraordinária não apenas na África mas em todos os continentes, exceto na Antártica (Harlan \& Wet, 1969).

O Dr. Glenn W. Burton do Departamento de Agricultura dos Estados Unidos (USDA-ARS) desenvolveu, a partir da década de 1930, um programa de melhoramento genético de gramíneas do gênero Cynodon em cooperação com outros cientistas da Universidade da Georgia, e obteve gramíneas forrageiras bem adaptadas ao uso em pastagens. Dentre essas destacam-se o capim 'Coastcross' e os novos capins 'Tifton 85' e 'Florakirk' . A partir de 1943, C. dactylon deu origem a cultivares de interesse forrageiro que resultaram 
numa revolução na indústria pecuária dos estados sulinos nos EUA (Harlan, 1970).

Partindo de Cynodon dactylon, uma espécie cosmopolita considerada de difícil erradicação, Burton (1947) obteve o primeiro cultivar denominado 'Coastal' bermuda através do cruzamento de uma variedade local, var. dactylon e um tipo sul-africano, provavelmente a var. elegans. O cv 'Coastal' foi largamente distribuído no sudeste dos EUA e uma área considerável foi implantada (Pedreira, 1996).

O cultivar mais conhecido e de grande aceitação no Brasil foi obtido pelo Dr. Burton na Coastal Plain Experiment Station, Georgia, tendo recebido o nome de 'Coastcross-1' e correspondia a um material com boas características agronômicas e bom valor nutritivo (Burton, 1972). O cv 'Coastcross-1' é o produto do cruzamento entre o cv. Coastal e Cynodon nlemfuënsis var robusta originária do Quênia, variedade esta de elevada digestibilidade comparativamente às outras gramas bermudas.

Pedreira et al. (1998) relatam que, devido a preocupações com a resistência de 'Coastcross-1' ao frio, desenvolveu-se um melhoramento desta variedade através da sua exposição à radiação gama $\left({ }^{60} \mathrm{Co}\right)$ no Estado do Tennessee. Disto resultou o 'Coastcross-1M3', posteriormente chamado 'Coastcross-2', e este material foi distribuído a produtores e demais interessados pela Coastal Plain Experiment Station em Tifton, e hoje é simplesmente denominada de 'Coastcross'.

Em 1975 a 'Callie' bermudagrass (Cynodon dactylon var. aridus) foi hibridizada com 'Tifton 44' bermudagrass para criação do híbrido F1-'Florakirk', planta de maior tolerância ao frio e resistência à ferrugem comparativamente à 'Callie'. Esta nova planta foi lançada como cultivar em 1994 pela Florida Agricultural Experiment Station (Mislevy et al., 1995) e corresponde a um capim bermuda de estação quente, estolonífero, com estolões glabros (sem pêlos), rizomatoso, de colmos folhosos e ramificados que podem atingir até $70 \mathrm{~cm}$ de altura (Mislevy et al., 1995; Pedreira, 1996). 
O cv. 'Tifton 85' é um híbrido interespecífico (Cynodon spp.), selecionado do cruzamento entre uma bermuda (Cynodon dactylon) do sul da África (PI290884) e o capim bermuda cv 'Tifton 68'(C. nlemfuënsis), em que introduziu-se genes para resistência ao frio, seca e pisoteio. O 'Tifton 85' é uma planta de porte mais alto, com hastes grandes, folhas finas e de côr verde mais escura que os outros híbridos, apresentando rizomas bem desenvolvidos (Burton et al.,1993). Este cultivar foi selecionado por causa de seu elevado potencial produtivo de forragem com elevada digestibilidade comparativamente às outras bermudas (bermudagrass) (Sollenberger et al., 1995).

Ambos, 'Florakirk' e 'Tifton 85', são gramíneas produtivas capazes de suportar elevadas taxas de lotação com excelente ganho de peso para animais em crescimento (Sollenberger et al., 1995). Segundo Mislevy \& Pate (1996), os cultivares 'Florakirk' e 'Tifton 85' têm-se mostrado como de grande persistência em testes realizados durante os últimos 20 anos na Flórida.

\subsection{Alguns fatores de produção de plantas forrageiras}

\subsubsection{Relações envolvendo a luz em comunidades vegetais}

Apesar dos fatores individuais do ambiente não serem forças isoladas que atuam sobre os organismos, a radiação solar é de fundamental importância como fonte essencial e direta de energia para o desenvolvimento de todos os vegetais verdes, por sua ligação com a fotossíntese e por correlacionar-se

direta ou indiretamente com um grande número de processos ligados ao crescimento (Shain, 1961; Gardner et al., 1985; Pedreira et al., 1998). O papel fundamental da radiação solar advém do fato de que mais de $90 \%$ do peso seco das plantas provém da assimilação fotossintética de carbono.

A conversão de energia luminosa em química através da fotossíntese é o processo básico e necessário para o estabelecimento de uma cadeia alimentar. Deste modo, o funcionamento, a estrutura e sobrevivência de qualquer ecossistema está fortemente dependente da luz, e seus efeitos na 
fotossíntese devem ser analisados em termos de intensidade e qualidade (Whatley \& Whatley, 1982). Os comprimentos de onda correspondentes à luz visível (400 a $700 \mathrm{~nm}$, radiação fotossinteticamente ativa) são os que mais afetam a fotossíntese, e correspondem àqueles que vão do azul ao vermelho (Whatley \& Whatley, 1982; Cooper, 1983; Gardner et al., 1985; Nabinger, 1997; Pedreira et al., 1998).

A "captura de energia" ou a interceptação luminosa depende de uma superfície captadora (folhas), cujo tamanho e eficiência de transformação da energia luminosa em energia química depende da disponibilidade de nutrientes assegurada pelos processos de absorção (raízes) e reciclagem de nutrientes no sistema (Nabinger, 1997). Cooper (1983) relatou que a eficiência das plantas forrageiras na conversão de energia luminosa em matéria seca também é dependente da eficiência fotossintética de folhas individuais, do arranjo das folhas no dossel e da natureza da produção por plantas individuais (partição dos fotoassimilados).

Segundo Bernardes (1987), muitos fatores estão envolvidos na determinação da produtividade agrícola, sendo a fotossíntese um dos mais importantes. Lawlor (1995) ressalva que sendo a fotossíntese a força propulsora do crescimento vegetal, a taxa de crescimento da cultura (TCC) é fortemente determinada pelo percentual de luz interceptado. Bernardes (1987) salientou que vários aspectos morfológicos (densidade da cobertura vegetal, distribuição horizontal das folhas, distribuição vertical entre folhas, ângulo foliar) e fisiológicos (idade da folha, tipo e tamanho da folha, flutuação na densidade e qualidade da luz, saturação luminosa) estão envolvidos na interceptação de luz pelas culturas.

Brougham (1957) mostrou que para máxima produtividade de forragem pelo pasto, é essencial que toda a luz incidente seja utilizada pelo tecido fotossintético, e afirmou que contínuas mudanças na interceptação luminosa pelas folhas do pasto são devidas ao estádio de crescimento, espécie da planta e estação do ano. Ludlow (1978) relatou que apreciáveis reduções no 
crescimento de plantas individuais e da pastagem, tanto tropicais quanto temperadas, são devidas ao sombreamento, à diminuição da radiação solar que penetra no perfil do pasto, ou à ocorrência de dias nublados.

Brougham (1956) demonstrou a relação direta entre a taxa de rebrota e a interceptação de luz pelas folhas de uma pastagem de azevém submetida a diferentes intensidades de desfolha. Plantas cortadas a 2,5; 7,5 e 12,5 cm do solo interceptaram 95\% da luz incidente, respectivamente, aos 24, 16 e 4 dias após o corte, sendo que aquela porcentagem de interceptação estava associada com a maior taxa de acúmulo de matéria seca pela pastagem.

Shain (1961) comentou que uma atenção especial deveria ser destinada para a qualidade e intensidade da luz disponível no dossel do pasto, pois esses fatores interferem ativamente sobre o desenvolvimento das plantas. Segundo Ludlow (1978), são necessários mais estudos para determinar se ocorrem perdas ou ganhos na pastagem devido ao aumento da proporção de luz direta e difusa ao longo de seu perfil.

Kephart et al. (1992) evidenciaram que menos luz foi interceptada pelas folhas dentro do dossel de um pasto para um tratamento de baixa radiação, resultando sistematicamente na limitação da fotossíntese para crescimento nos tratamentos sombreados. Segundo Bernardes (1987), em situações onde a radiação difusa fica proporcionalmente mais importante que a radiação direta, maiores densidades populacionais, ou comunidades vegetais com índice de área foliar (IAF) mais elevado, são favorecidas.

A interceptação e distribuição de luz dentro da comunidade vegetal foi considerada por Pearce et al. (1967) como de grande influência sobre a produção de matéria seca, embora a utilização da energia solar possa ser restringida por outros fatores como temperatura inadequada, déficit hídrico ou déficit nutricional (Cooper \& Tainton, 1968). A utilização ótima da luz solar incidente foi proposta por Warren-Wilson (1961) como sendo aquela que ocorre quando a folhagem de um dossel fechado recebe luz de intensidade uniforme e relativamente baixa, e com as folhas basais permanecendo no ponto de 
compensação luminosa. Essa situação ideal poderia existir, ao menos teoricamente, através de um arranjo espacial adequado de uma área foliar apropriada.

Lawlor (1995) comentou que a produção de forragem depende mais das características do pasto como índice de área foliar, duração da área foliar (ou longevidade da folha) e estrutura do dossel, fatores estes mais determinantes da interceptação luminosa que da eficiência fotossíntetica.

\subsection{2 Índice de área foliar}

Quando se estuda comunidades vegetais, agrícolas ou não, a área foliar útil é expressa através do índice de área foliar (IAF). O desenvolvimento do conceito de índice de área foliar (IAF, área de uma face das folhas dividida pela área de solo que ocupam) por Watson (1947) possibilitou a racionalização e um melhor entendimento das relações entre a interceptação luminosa e o acúmulo de matéria seca das plantas.

Num valor de IAF chamado "ótimo" (IAFótimo) a interceptação de aproximadamente toda a luz incidente com um mínimo de auto-sombreamento proporciona o máximo valor de taxa de crescimento da cultura (TCC, peso de matéria seca acumulado por unidade de área por unidade de tempo) (Watson, 1958; Brown \& Blaser, 1968; Rhodes, 1973). O valor de IAF que proporciona 95\% de interceptação luminosa e no qual o valor de TCC está próximo do

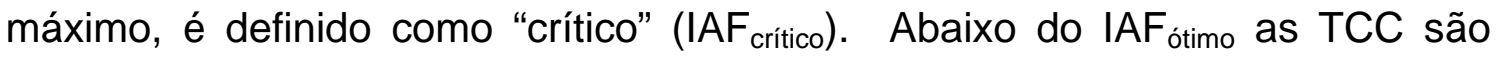
dependentes do IAF e são mais reduzidas quando a interceptação da luz incidente é incompleta. Acima do $\mathrm{IAF}_{\text {ótimo }}$ a redução da TCC é causada pelo aumento das perdas respiratórias, consequência do sombreamento excessivo, que resulta num balanço negativo de carbono (Hay \& Walker, 1989).

Brougham (1957) demonstrou que diferenças no IAFótimo entre gramíneas, leguminosas e pastagens consorciadas podem ser explicadas por diferenças de arquitetura do dossel. Em geral, a predominância de folhas 
horizontais, como ocorre nos trevos (Trifolium spp.) proporciona a habilidade de interceptar mais luz com um IAF menor, o que, todavia, não deve ser visto como uma vantagem em termos produtivos. Num estudo com gramíneas de diferentes arquiteturas, Sheehy \& Cooper (1973) observaram que os valores de TCC variaram de acordo com a morfologia da planta e com o coeficiente de extinção luminosa $\mathrm{k}\left(\mathrm{k}=-\left[\log _{\mathrm{e}}\left(\mathrm{I} / \mathrm{I}_{0}\right)\right] / / \mathrm{AF}\right.$, onde $\mathrm{I}$ e $\mathrm{I}_{0}$ são os valores de irradiância abaixo e acima da folhagem, respectivamente). Variedades mais eretas apresentaram maiores valores de TCC e menor k, enquanto que as mais prostradas tiveram TCC mais baixa e maior $k$. Embora diferenças entre as taxas de fotossíntese de folhas individuais não tenham sido notadas, a eficiência de conversão da energia luminosa foi maior nas plantas eretas $(7,8 \%)$ que nas prostradas $(3,9 \%)$.

Com o aumento no índice de área foliar ocorre um aumento na interceptação luminosa e na eficiência de uso da radiação fotossinteticamente ativa, o que ocasiona uma aceleração na taxa de crescimento em condições ambientais favoráveis (Brown \& Blaser, 1968; Humphreys, 1966ab). Segundo Brown \& Blaser (1968), a complexidade de manejo das pastagens é melhor entendida quando vários conceitos de crescimento e utilização são analisados conjuntamente.

A utilização de procedimentos para obter máxima produção pode depender mais de características morfológicas do que da interceptação de luz ou da área foliar. No entanto, de acordo com Brougham (1956) e Donald \& Black (1958), uma arquitetura foliar capaz de interceptar uma elevada proporção de energia luminosa é de grande importância para o crescimento das culturas.

Apesar de algumas limitações no uso do conceito de IAF no manejo de pastagens, que surgem principalmente devido a mudanças nas características fotossintéticas, na arquitetura e composição botânica do pasto, Brown \& Blaser (1968) concluíram que o IAF relacionado à interceptação de luz parece uma 
forma útil para entender a produção da forragem e o desenvolvimento de melhores variedades e práticas de manejo.

O rápido aumento do IAF em tratamentos de elevado IAF residual se dá em função do aumento da expansão de folhas já existentes (Bommer, 1966). A área foliar remanescente após o corte implica em uma maior ou menor interceptação de energia luminosa no momento que as plantas iniciam a sua rebrota (Jacques, 1973).

Humphreys \& Robinson (1966) relatam que a manutenção de uma área fotossintética após o corte para a recuperação das plantas forrageiras é importante. Contudo, a importância da área foliar remanescente pode ser limitada pela longevidade e eficiência do tecido fotossintético (Brown et al., 1966), uma vez que as folhas mais velhas e posicionadas mais próximas à superfície do solo são frequentemente de baixa eficiência fotossintética (Jewiss \& Woledge, 1967). Por isso mesmo Ward \& Blaser (1961), apesar de reconhecerem a importância do índice de área foliar remanescente, atribuíram pouca aplicação prática a este conceito no estabelecimento de normas de manejo da pastagem.

Se, por um lado, a área foliar total é de fundamental importância tanto do ponto de vista fisiológico como agronômico, por outro lado é importante saber como essa área foliar está distribuída ao longo do perfil do dossel (Warren-Wilson, 1959). Essa distribuição não só tem implicações do ponto de vista morfológico, afetando a proporção da forragem que é removida pelo corte ou pastejo a uma certa altura, mas também é importante fisiologicamente nos estudos de fotossíntese e competição por luz, especialmente em pastos consorciados. Se uma área considerável da folhagem estiver confinada a uma estreita camada horizontal, a superposição de folhas resultará em excessivo auto-sombreamento, especialmente se as folhas forem grandes (WarrenWilson, 1961). A mesma área foliar, se distribuída por uma faixa maior do perfil do dossel, receberá iluminação mais uniforme, resultando em uma maior TCC. 
A distribuição do IAF pelo perfil do dossel em variedades com diferentes morfologias pode explicar, parcialmente, eventuais diferenças observadas em produção, embora esteja comprovada a existência de interações entre a morfologia e o regime de desfolha (Rhodes, 1971ab). Quando os intervalos entre desfolhas sucessivas são curtos, o cultivar com maior proporção do IAF na parte inferior do dossel apresenta o maior IAF residual, o que assegura uma rápida recuperação inicial após desfolha através de uma maior interceptação luminosa. Em contrapartida, se o período de rebrota é longo, os cultivares de crescimento mais alto e ereto, com maiores proporções de IAF nas regiões intermediária e superior do dossel, têm tempo suficiente para acumular um grande IAF e apresentam um menor k, sendo, portanto, mais produtivos.

Donald \& Black (1958) sugeriram que os métodos de lotação contínua oferecem uma oportunidade para manter a pastagem no IAF em que praticamente toda a radiação incidente durante a estação favorável é interceptada, maximizando, desta forma, a assimilação fotossintética. Entretanto, Gomide (1997) afirmou que sob condições de pastejo é praticamente impossível manter um IAF ótimo. Valores baixos de IAF poderão causar redução no crescimento da planta devido a inadequada interceptação de luz. Em contrapartida, em situações de alto IAF, há aumento na atividade respiratória e acelerada senescência de folhas.

\subsection{Aplicação dos conceitos}

\subsubsection{Manejo da desfolha}

Segundo da Silva \& Pedreira (1997) há duas características das gramíneas forrageiras perenes que são centrais para o entendimento dos efeitos do manejo sobre a produção das pastagens. Primeiro, devido ao fato de o pasto apresentar um rápido turnover (renovação) de tecidos, todo o material que permanecer não colhido é logo perdido por senescência. A segunda característica é que são justamente os tecidos fotossintéticos (principalmente as 
folhas) aqueles colhidos pelo corte ou pastejo. Isso causa reduções na área foliar e na interceptação de luz pelo pasto, reduzindo a fotossíntese e, consequentemente, a capacidade da planta de produzir novas folhas.

Parsons (1988) propôs que o objetivo do manejo da pastagem é encontrar o compromisso ideal entre as exigências conflitantes da planta forrageira, que precisa conservar sua área foliar para fotossíntese, e a necessidade fundamental de remover esse tecido através de corte ou pastejo. De acordo com Hodgson (1990) as variáveis do pasto que apresentam uma maior consistência sobre a produção de forragem são a altura do pasto e o índice de área foliar (IAF), especialmente em se tratando de gramíneas forrageiras prostradas, de porte baixo e com alto potencial de perfilhamento.

A forma de utilização das pastagens varia em função da frequência com que a mesma é pastejada, ou seja, do intervalo de tempo entre um pastejo e outro, do tempo em que os animais permanecem na mesma área e da intensidade com que este pastejo remove a parte aérea das plantas (Nabinger, 1997). Desfolhas mais frequentes e intensas reduzem a área foliar reduzindo, desta maneira, a interceptação de luz e o crescimento das plantas forrageiras (Brougham, 1956). Da Silva \& Pedreira (1997) salientam que desfolhas frequentes e intensas podem resultar em crescimento mais lento da pastagem uma vez que reduzem a oportunidade para o restabalecimento pleno dos níveis originais de reservas orgânicas pela planta forrageira, além de poderem causar redução na absorção de nutrientes e água do solo.

\subsubsection{Cynodon spp. em sistemas de produção animal}

Ao longo dos anos as plantas do gênero Cynodon despertaram grande interesse e ganharam popularidade devido à sua facilidade de cultivo, alta produção de forragem (20 a $25 \mathrm{t} \mathrm{MS} \mathrm{ha}^{-1} \mathrm{ano}^{-1}$ ) de bom valor nutritivo (11 a 13\% de proteína bruta e 58 a 65\% de digestibilidade) (Pedreira, 1996). No entanto, segundo da Silva \& Pedreira (1997) poucos têm sido os trabalhos que têm 
gerado informações suficientes para que o planejamento de estratégias de desfolha eficientes possam ser elaboradas visando máxima utilização do pasto, sustentabilidade e produtividade. A maior parte dos trabalhos é relacionada com taxa de lotação, níveis de fertilizantes e avaliação de desempenho, informações estas importantes mas, contudo, pouco relevantes para a solução dos conflitos de interesses entre planta e animal em ecossistemas de pastagens.

Vilela \& Alvim (1996) mostraram que, em dois anos de pastejo em Coastcross com vacas leiteiras sendo suplementadas com $6 \mathrm{~kg}$ de concentrado, pôde-se obter taxa de lotação média de 6,6 UA ha-1 e produção de leite por área de $36.865 \mathrm{~kg} \mathrm{ha}^{-1} \mathrm{ano}^{-1}$ ou $101 \mathrm{~kg} \mathrm{ha}^{-1} \mathrm{dia}^{-1}$.

Milera et al (1988) obtiveram produções de leite em torno de 8 a $16 \mathrm{~kg}$ vaca $^{-1} \mathrm{dia}^{-1}$ em pasto de Coastcross com taxa de lotação variando de 2,7 a 4,5 vacas ha $^{-1}$. Lamela et al. (1984) estudaram o desempenho de vacas mestiças pastejando Coastcross e obtiveram produções de $9,3 \mathrm{~kg} \mathrm{vaca}^{-1} \mathrm{dia}^{-1}$.

Da Silva et al. (1998) inferiram que a lotação em pastagens de Cynodon durante o período de inverno pode atingir $3 \mathrm{UA} \mathrm{ha}^{-1}$, desde que conceitos referentes ao manejo adequado do pasto relacionados com frequência e intensidade de desfolha, reposição de nutrientes (Pedreira et al, 1998), etc., sejam praticados. Já Corsi \& Martha Jr. (1998) relataram que o gênero Cynodon é composto por plantas com flexibilidade limitada de manejo quanto a utilização sob pastejo, principalmente nas situações onde o pasto é mantido com elevada quantidade de resíduo pós-pastejo. Sob estas condições o desempenho animal se mantém ao redor de $0,5 \mathrm{~kg}_{\text {animall }}{ }^{-1} \mathrm{dia}^{-1}$. Relataram que com manejo adequado, é possível obter ganhos de peso diários da ordem de 1,0 kg animal' ${ }^{1} \mathrm{dia}^{-1}$.

Trabalhos realizados em São Carlos, SP (Corrêa, 1997) mostraram que pastagens de Coastcross têm elevado potencial, tanto em termos de desempenho animal, como de produtividade. Foram relatados ganhos de peso em novilhos canchim $x$ nelore de 0,71 e 0,60 $\mathrm{kg}_{\text {animal }}{ }^{-1} \mathrm{dia}^{-1}$, correspondendo 
a ganhos de 900 e $780 \mathrm{~kg} \mathrm{ha}^{-1}$ verão ${ }^{-1}$ ( 140 dias), quando as taxas de lotação foram de 6,6 e 7,6 UA ha-1 ${ }^{-1}$, respectivamente.

Esses dados revelam o potencial que essas espécies têm para gerar produção de leite e carne em regime de pastejo, tendo em vista algumas diferenças relacionadas à qualidade da forragem, período de ocupação, lotação, genética animal, etc. No entanto, apresentam capacidade limitada para promover a compreensão e o entendimento da dinâmica de resposta da planta forrageira sob pastejo, uma vez que os dados têm como característica comum o fato de terem sido gerados em ensaios onde as variáveis estudadas não permitem o controle do estado e da estrutura do pasto. Estas características são fundamentais para a compreensão da origem e dinâmica das respostas de plantas forrageiras sob pastejo (Hodgson, 1990; da Silva \& Pedreira, 1997).

A fixação de parâmetros como intervalo entre cortes, taxas de lotação e/ou níveis de nitrogênio e uso de alimentos concentrados não assegura o controle efetivo das características estruturais e da dinâmica do pasto, uma vez que não levam em consideração atributos da planta forrageira propriamente ditos. Isto explica parte das inconsistências existentes entre os resultados de pesquisas e aqueles observados em condições de campo (da Silva \& Pedreira, 1997). Taxas de lotação e intervalos fixos entre pastejos são caracterizados por efeitos inconsistentes sobre os fatores pasto e animal, uma vez que mudanças no estado do pasto são passageiras e não controladas sob aquelas circunstâncias (Hodgson, 1990).

Da Silva \& Pedreira (1997) relataram que ecossistemas de pastagens são entidades bastante complexas e possuem uma série de componentes bióticos e abióticos que interagem entre si de diferentes maneiras. Assim, para a devida compreensão e entendimento da resposta das plantas forrageiras ao pastejo, torna-se essencial e crítico que parâmetros relacionados com sua biologia e ecologia sejam avaliados e considerados quando da idealização de estratégias de uso das pastagens como recurso produtivo (da Silva et al., 1998). 


\section{MATERIAL E MÉTODOS}

\subsection{Material}

\subsubsection{Espécie vegetal}

Segundo Mitidieri (1983), as espécies em estudo classificam-se, de acordo com o "Sistema Engler", como: divisão Angiosperma; classe Monocotyledoneae; ordem Graminales; família Gramineae; subfamília Eragrostideae; tribo Chloridoideae; gênero Cynodon; espécie Cynodon dactylon cv 'Florakirk' , Cynodon spp. cv 'Tifton 85' e Cynodon spp. cv 'Coastcross'.

\subsubsection{Local do experimento}

O ensaio foi conduzido na Unidade Experimental de Plantas Forrageiras (UEPF) em área do Departamento de Produção Animal da Escola Superior de Agricultura "Luiz de Queiroz", Universidade de São Paulo, no município de Piracicaba, Estado de São Paulo, localizado a $22^{\circ} 42$ '30" latitude sul, $47^{\circ} 38^{\prime} 00^{\prime \prime}$ longitude oeste e a uma altitude de $546 \mathrm{~m}$ (Ometto, 1989). O período experimental foi de 01 de julho a 30 de dezembro de 1998, com duração de 183 dias. 


\subsubsection{Solo da área experimental}

O experimento foi instalado em solo classificado como terra roxa estruturada eutrófica, com horizonte A moderado e de textura argilosa/muito argilosa. O resultado da análise do solo encontra-se na Tabela 1. Devido à elevada fertilidade do solo não foram realizadas práticas de calagem no momento da implantação do ensaio.

Tabela 1. Características químicas do solo da área experimental.

\begin{tabular}{|c|c|c|c|c|c|c|c|c|c|}
\hline $\mathrm{pH}$ & M.O & $\mathrm{P}$ & K & $\mathrm{Ca}$ & $\mathrm{Mg}$ & $\mathrm{H}+\mathrm{Al}$ & SB & $\mathrm{T}$ & V \\
\hline $\mathrm{CaCl}_{2}$ & $\mathrm{~g} \mathrm{~kg}^{-1}$ & $\mathrm{mg} \mathrm{dm}^{-3}$ & & & $---c$ & & & & $\%$ \\
\hline 5,4 & 37,0 & 99 & 0,46 & 7,5 & 2,6 & 3,0 & 10,6 & 13,6 & 78,0 \\
\hline
\end{tabular}

\subsubsection{Clima}

Conforme o sistema Köppen, o clima da região de Piracicaba pode ser classificado como Cwa, isto é, mesotérmico úmido subtropical de inverno seco, onde a temperatura do mês mais frio é inferior a $18{ }^{\circ} \mathrm{C}$ e a do mês mais quente ultrapassa os $22{ }^{\circ} \mathrm{C}$ (Brasil, 1960). Os dados climáticos referentes ao período experimental encontram-se na Tabela 2. Os dados foram obtidos no posto meteorológico do Departamento de Ciências Exatas ESALQ-USP, Iocalizado próximo à área experimental.

\subsubsection{Animais}

Para a implantação e manutenção dos tratamentos experimentais foram utilizados ovinos mestiços da raça Santa Inês, provenientes do rebanho do setor de Ovinocultura da ESALQ. 
Tabela 2: Precipitação pluvial, radiação solar global e temperaturas médias mensais do ar (máxima, mínima e média) durante o período experimental.

\begin{tabular}{cccccc}
\hline Mês & Radiação & Precipitação & \multicolumn{3}{c}{ Temperatura $\left({ }^{\circ} \mathbf{C}\right)$} \\
\cline { 4 - 6 } & Global $\left(\mathbf{c a l . c m} \mathbf{c m}^{-2}\right)$ & $(\mathbf{m m})$ & Máxima & Mínima & Média \\
\hline Julho & 299 & 13,9 & 25,9 & 10,8 & 18,4 \\
Agosto & 310 & 21,8 & 27,4 & 14,4 & 20,9 \\
Setembro & 335 & 89,3 & 27,7 & 15,3 & 21,5 \\
Outubro & 369 & 183,1 & 27,1 & 16,3 & 21,7 \\
Novembro & 474 & 26,6 & 30,0 & 16,5 & 23,2 \\
Dezembro & 441 & 292,0 & 30,0 & 19,2 & 24,6 \\
\hline
\end{tabular}

Fonte: Arquivos do Departamento de Ciências Exatas - ESALQ/USP (1998)

\subsubsection{Pastagens}

Os pastos foram implantados em março de 1996 através de mudas, sendo que, devido às adversidades climáticas e ao baixo percentual de pegamento das mudas, fez-se o replantio de algumas parcelas durante os meses de fevereiro e março de 1997. Em várias ocasiões durante o estabelecimento fez-se necessário a limpeza das parcelas em virtude da infestação com plantas invasoras, especialmente Brachiaria spp., Cyperus spp., Panicum maximum e Cynodon dactylon (grama-seda). Adubações nitrogenadas foram realizadas durante o decorrer do ano de 1997, as quais totalizaram 150 $\mathrm{kg} \mathrm{N} \mathrm{ha}^{-1} \mathrm{ano}^{-1}$ na forma de sulfato de amônio.

Em janeiro de 1998 realizou-se um corte de uniformização, seguido de uma adubação com $40 \mathrm{~kg} \mathrm{~N}^{-1}$ na forma de sulfato de amônio. Além do controle de invasoras, foi também necessário o controle de cigarrinha das pastagens (Deois spp. e Zulia entreriana) e lagarta do cartucho do milho (Spodoptera frugiperda).

Em março de 1998 foi realizado um novo corte de uniformização para dar início ao experimento (Foto 1). Em função de uma nova infestação com 
cigarrinha e lagarta do cartucho do milho, o ensaio só pôde ser iniciado em 3 de junho de 1998.

\subsection{Métodos}

\subsubsection{Delineamento experimental e tratamentos}

O ensaio foi realizado seguindo um delineamento de blocos completos casualizados, com parcelas subdivididas (split-plot). Os tratamentos corresponderam a três cultivares de Cynodon spp., 'Tifton 85', 'Florakirk' e 'Coastcross', que foram alocados às parcelas, e de quatro condições de pasto, geradas por ovinos sob regime de lotação contínua, alocadas nas sub-parcelas. Cada condição de pasto correspondeu a uma altura média de 5, 10, 15 e 20 $\mathrm{cm}$, mantidas constantes através da adição ou retirada de animais das parcelas durante o transcorrer do experimento. Neste arranjo, foram utilizadas quatro repetições. Assim, o ensaio apresentou um total de 48 unidades experimentais (4 blocos x 12 unidades/ bloco) com uma área média de $400 \mathrm{~m}^{2}$ cada, separadas por tela de 1,20 m de altura para delimitação dos piquetes (unidades experimentais) e contenção dos animais. A área experimental total compreendeu 2,0 ha (Figura 1, Foto 2). 


\begin{tabular}{|c|c|c|c|c|c|c|c|c|c|c|c|}
\hline \multicolumn{3}{|c|}{ BLOCO I } & \multicolumn{3}{|c|}{ BLOCO II } & \multicolumn{3}{|c|}{ BLOCO III } & \multicolumn{3}{|c|}{ BLOCO IV } \\
\hline T 10 & F 15 & C 10 & F 05 & T 10 & C10 & F 20 & T 15 & C 10 & T 20 & F 05 & C 05 \\
\hline T 15 & F 10 & C 05 & F 10 & T 15 & C 20 & F 05 & T 20 & C 15 & T 15 & F 10 & C 20 \\
\hline T 20 & F 05 & C 15 & F 15 & T 20 & C 15 & F 15 & T 10 & C 20 & T 10 & F 20 & C 10 \\
\hline T 05 & F 20 & C 20 & F 20 & T 05 & C 05 & F 10 & T 05 & C 05 & T 05 & F 15 & C 15 \\
\hline
\end{tabular}

Figura 1: Representação esquemática da distribuição dos tratamentos na área experimental. T:Tifton-85; F:Florakirk; C:Coastcross; 05, 10, 15 e 20 intensidades de pastejo em $\mathrm{cm}$.

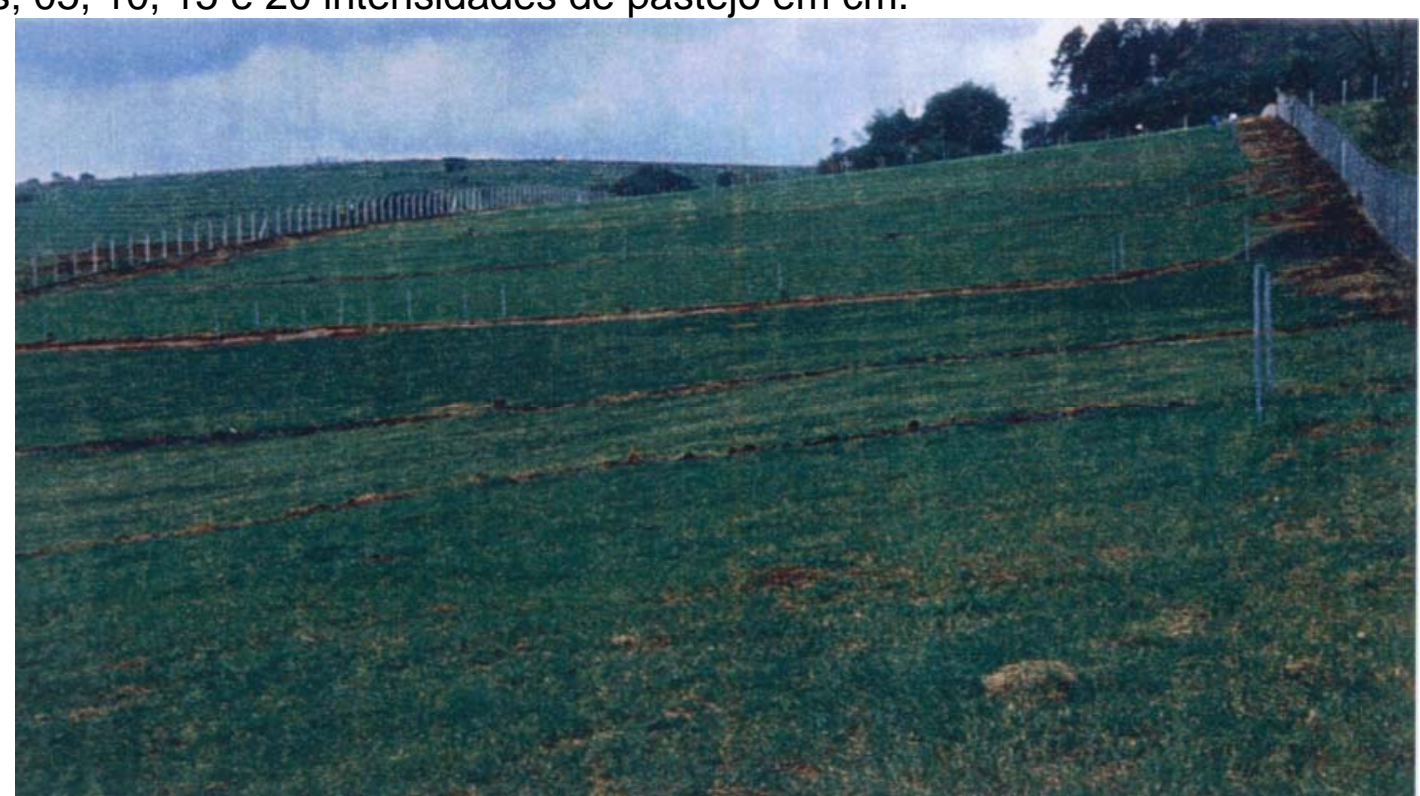

Foto 1: Vista geral da área experimental após corte de uniformização realizado em março de 1998. 


\subsubsection{Instalação e monitoramento das condições experimentais}

Em 3 de junho de 1998 os animais foram alocados às unidades experimentais que haviam atingido a altura pré-determinada para cada tratamento. À medida que as demais unidades experimentais atingiam a altura desejada, animais eram adicionados dando início ao pastejo. Em 1 de julho todas as subparcelas apresentaram condição para que fossem iniciadas as avaliações.

Durante a condução do experimento, de julho a dezembro de 1998, foram realizadas quatro adubações nitrogenadas com sulfato de amônio. A primeira em 8 de julho (40 $\mathrm{kg} \mathrm{N} \mathrm{ha}^{-1}$ ), a segunda em 19 de setembro (40 kg N $\mathrm{ha}^{-1}$ ), a terceira em 21 de outubro (50 $\mathrm{kg} \mathrm{N} \mathrm{ha}^{-1}$ ) e a quarta em 7 de dezembro $\left(25 \mathrm{~kg} \mathrm{~N} \mathrm{ha}^{-1}\right)$. As quantidades de fertilizante aplicadas foram dimensionadas a fim de que um acúmulo mínimo de forragem pudesse ser obtido para manter pelo menos dois animais nas unidades experimentais.

A intensidade de pastejo (altura média dos pastos) foi monitorada semanalmente através da tomada de 20 leituras em cada parcela com o "rising plate meter" ou prato ascendente (duas vezes por semana), obtendo-se a altura comprimida média. Uma vez por mês era feita a calibração da altura comprimida com a altura não comprimida (régua), gerando o valor de altura usado como referência para o monitoramento dos tratamentos (Foto 3). Animais foram adicionados ou removidos nas parcelas no caso da altura estar acima ou abaixo da desejada, respectivamente.

\subsubsection{Calibração: Altura x Massa}

Uma vez ao mês era feita a calibração entre altura e massa de forragem, com a finalidade de relacionar a altura média do pasto com a massa de forragem existente e também para o cálculo de acúmulo de matéria seca, minimizando assim a necessidade de amostragens destrutivas. 
Com anéis de 0,25 $\mathrm{m}^{2}$ de área, foram escolhidos dois pontos de cada parcela procurando sempre o ponto mais baixo e o ponto mais alto a fim de se obter a maior amplitude possível de alturas. Foi medida a altura dentro do anel com a régua e com o prato ascendente, depois a forragem foi cortada ao nível do solo, lavada para eliminação de eventuais resíduos de terra e fezes, seca em estufa a $65^{\circ} \mathrm{C}$ até massa constante e pesada. Assim, após determinada a massa seca, estabeleceu-se através de regressão linear a relação entre altura e massa para cada cultivar.

$$
M=a+b h
$$

sendo:

$M=$ massa de forragem, em $\mathrm{kg} \mathrm{MS} \mathrm{ha}^{-1}$;

$\mathrm{h}=$ altura, $\mathrm{em} \mathrm{cm}$.

\subsubsection{Acúmulo de forragem e composição botânica}

O acúmulo de forragem foi medido dentro de gaiolas de exclusão, em número de 3 por parcela, compreendendo uma área de aproximadamente 0,5 $\mathrm{m}^{2}(70 \mathrm{~cm} \times 70 \mathrm{~cm})$ cada e observando-se um intervalo de 21 dias entre amostragens sucessivas. Após a amostragem as gaiolas eram rotacionadas nas unidades experimentais e ancoradas em novos pontos representativos da condição (altura média) das mesmas no momento do rodízio.

Os cálculos de acúmulo de forragem foram feitos com base no método agronômico da diferença conforme a equação I (Davies et al., 1993).

$$
\begin{aligned}
& \mathrm{AF}=\mathrm{MF}_{\mathrm{g}}-\mathrm{Mf}_{\mathrm{p}}(\mathrm{I}) \text {, onde: } \\
& \mathrm{AF}=\text { acúmulo de forragem; } \\
& \mathrm{MF}_{\mathrm{g}}=\text { massa de forragem sob a gaiola, no último dia de exclusão; } \\
& \mathrm{MF}_{\mathrm{p}}=\text { massa média de forragem na unidade experimental no dia } \\
& \text { da colocação das gaiolas. }
\end{aligned}
$$




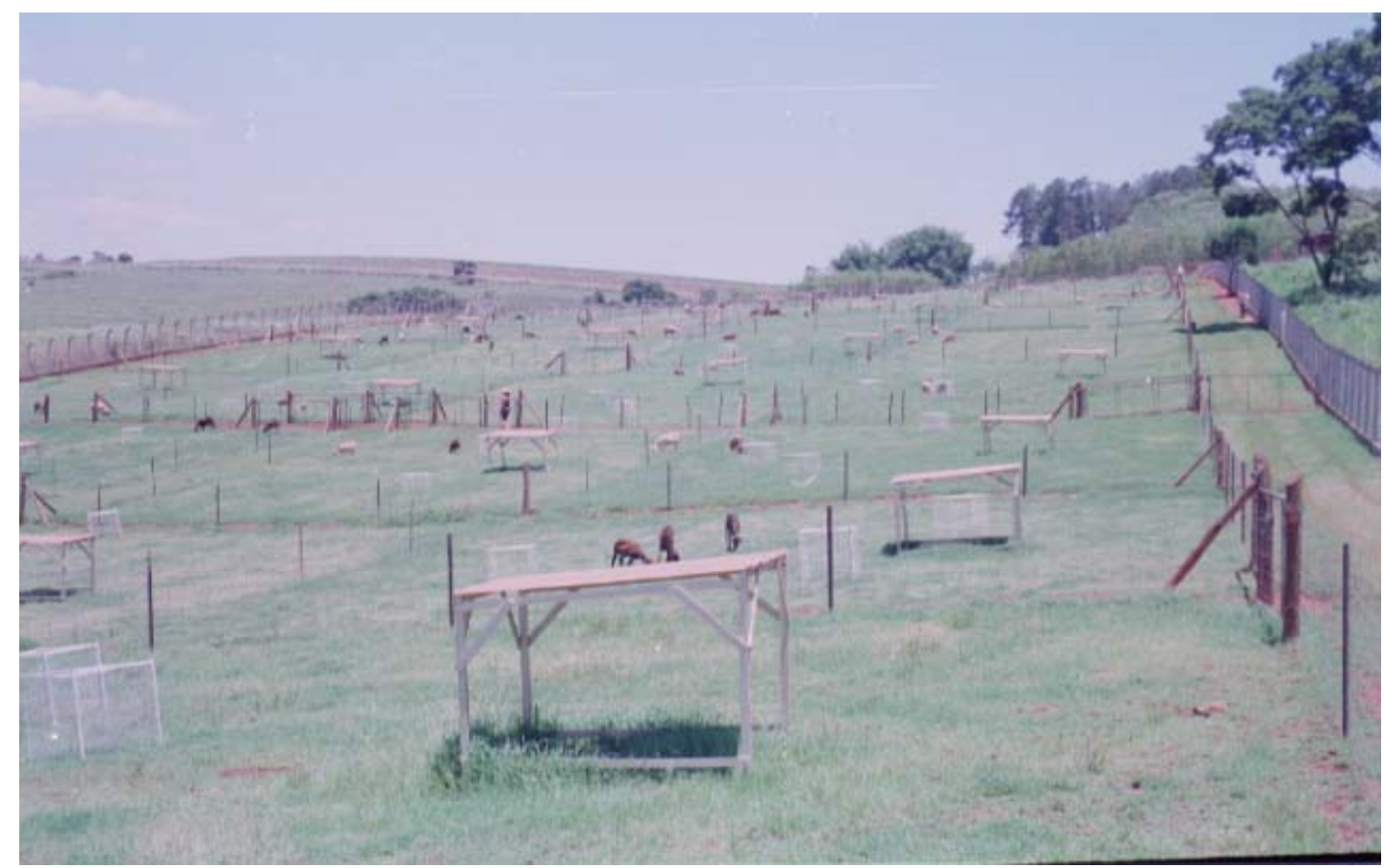

Foto 2: Vista geral da área experimental após implantação e início do ensaio.

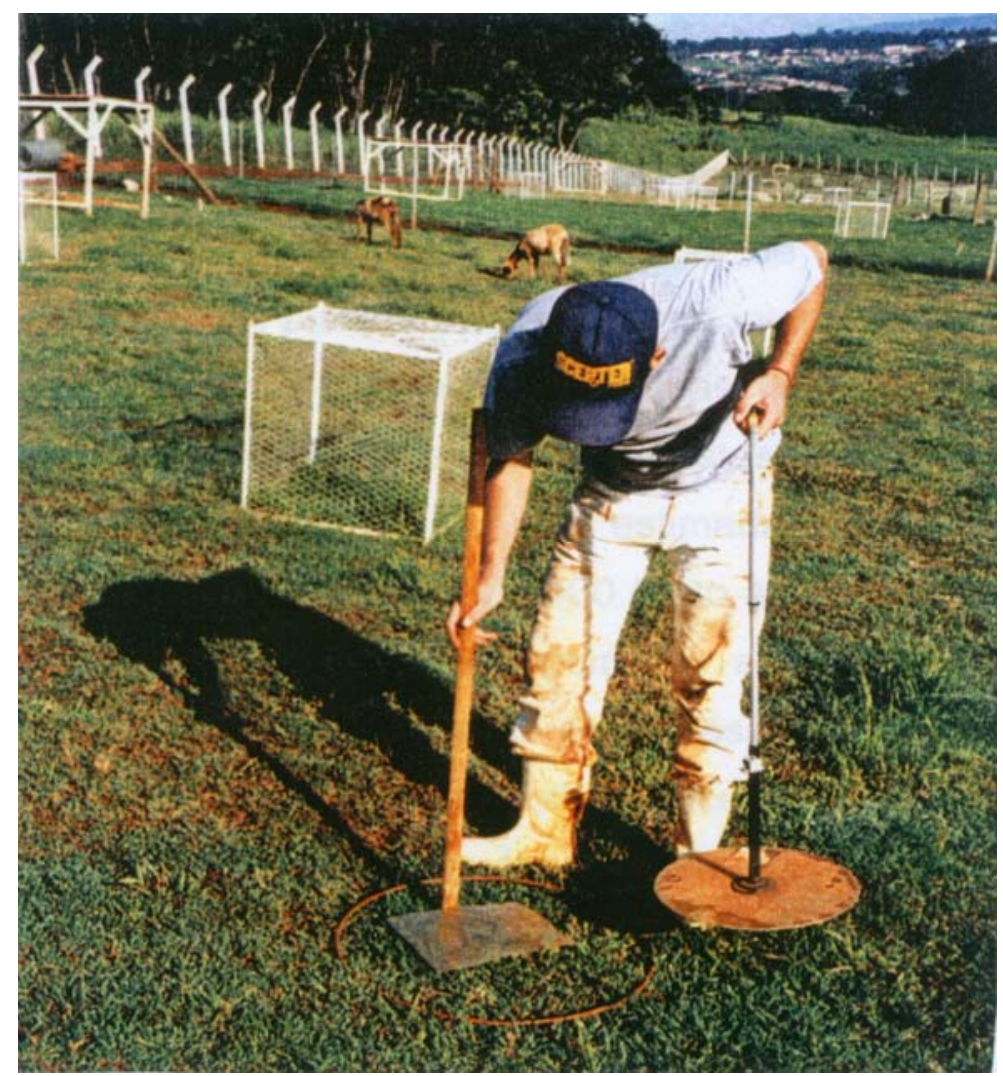

Foto 3: Ilustração de material experimental utilizado na coleta de dados. 
O acúmulo de forragem começou a ser avaliado a partir do mês de agosto, porque em julho algumas das unidades experimentais não continham as gaiolas de exclusão necessárias a essa medida.

Os valores de MF usados nos cálculos de acúmulo foram estimados através da utilização das curvas de regressão linear entre altura e massa para cada cultivar conforme descrito na seção 3.2.3.

\subsection{5 Índice de área foliar e composição botânica/morfológica do pasto}

Para avaliação do índice de área foliar (IAF) foram cortados 2 quadrados de $25 \mathrm{~cm}$ de lado por unidade experimental respeitando um intervalo mensal entre amostragens sucessivas. A área amostrada correspondeu, sempre, a uma região da unidade experimental que estivesse com uma altura média correspondente àquela do tratamento $(5,10,15$ ou $20 \mathrm{~cm})$. A forragem era cortada ao nível do solo, acondicionada em sacos plásticos e refrigerada a $4{ }^{\circ} \mathrm{C}$. As amostras eram então lavadas, sub-amostradas e fracionadas manualmente em material vivo e morto. O pool de material vivo era então fracionado novamente em plantas invasoras e de interesse. Cada grupo assim formado foi adicionalmente fracionado em folhas (lâminas foliares) e hastes (haste e pseudohaste). Após a separação destes componentes, uma subamostra das lâminas verdes tinha sua área estimada através de um integrador de área foliar marca LI-COR modelo LI-3100 (Foto 4). Posteriormente, todos os componentes eram levados para secagem em estufa a $65{ }^{\circ} \mathrm{C}$ até massa constante. Após secagem, as amostras eram pesadas. Através das relações obtidas entre o peso seco e a área de folhas calculou-se a área total de folhas na área de coleta da amostra (625 $\mathrm{cm}^{2} /$ quadrado) e o IAF correspondente $\left(\mathrm{cm}^{2}\right.$ de folhas $/ \mathrm{cm}^{2}$ de solo).

A composição botânica do pasto foi obtida através do cálculo da participação relativa dos diferentes componentes (haste, folha, material morto) 
da forragem na massa seca total de cada amostra coletada, gerando-se assim a porcentagem de cada um dos componentes no pasto.

\subsubsection{Interceptação luminosa e coeficiente de extinção de luz}

As avaliações de interceptação luminosa foram realizadas usando-se um fotômetro tipo line quantum sensor modelo LI- acoplado a um medidor LICOR modelo LI-250 (Foto 5). Foram tomadas 6 leituras em pontos representativos de cada unidade experimental que geraram, por sua vez, um valor médio composto. As leituras foram realizadas ao redor das 12:00 horas sob céu claro, medindo-se a intensidade luminosa acima do pasto ( $\left.\mathrm{I}_{0}\right)$ e no nível do solo (I). A interceptação luminosa era calculada como:

$$
\text { Interceptação }=\left(I_{0}-I\right) / I_{0}
$$

Com os dados de IAF e interceptação luminosa, o coeficiente de extinção luminosa $(k)$ foi calculado como $k=\left[\log _{\mathrm{e}}\left(1 / \mathrm{I}_{0}\right)\right] / / \mathrm{IAF}$ (Sheehy \& Cooper, 1973; Madakadze et al., 1998), onde I e Io são os valores de irradiância abaixo e acima da folhagem, respectivamente.

\subsubsection{Análise estatística}

Os dados foram analisados utilizando-se o procedimento GLM (General Linear Models) do pacote estatístico SAS (Statistical Analysis System), versão 6.12 para Windows. Dentro deste procedimento optou-se pelo subprocedimento de medidas repetidas no tempo (Repeated Measures), uma vez que todas as variáveis em estudo foram coletadas ao longo de vários meses (SAS Institute, 1988). Desta forma foi possível detectar-se os efeitos das causas de variação principais (cultivar, bloco, altura), as interações entre elas (bloco $x$ cultivar e altura $x$ cultivar), além dos efeitos de tempo dentro de cada uma das causas de variação principais (tempo, tempo $x$ cultivar, tempo $\mathrm{x}$ bloco, tempo $\mathrm{x}$ altura, tempo $\mathrm{x}$ cultivar $\mathrm{x}$ bloco, tempo $\mathrm{x}$ altura $\mathrm{x}$ cultivar, etc.). 
Todos os conjuntos de dados foram testados, antes da análise geral global, com a finalidade de assegurar que as quatro prerrogativas básicas da análise de variância (aditividade do modelo, independência dos erros, normalidade dos dados e homogeneidade das variâncias) estavam sendo respeitadas. Utilizou-se o "LSMEANS" para a comparação de médias entre tratamentos. 


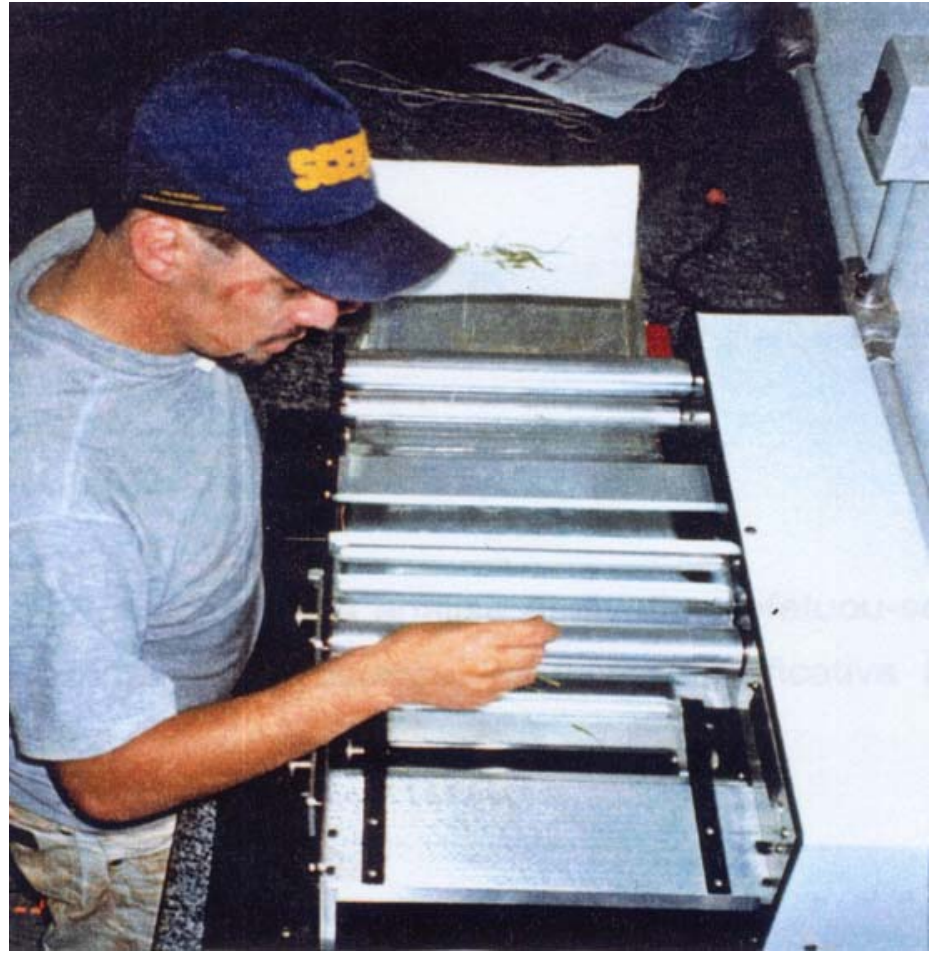

Foto 4: Ilustração do aparelho integrador de área foliar.

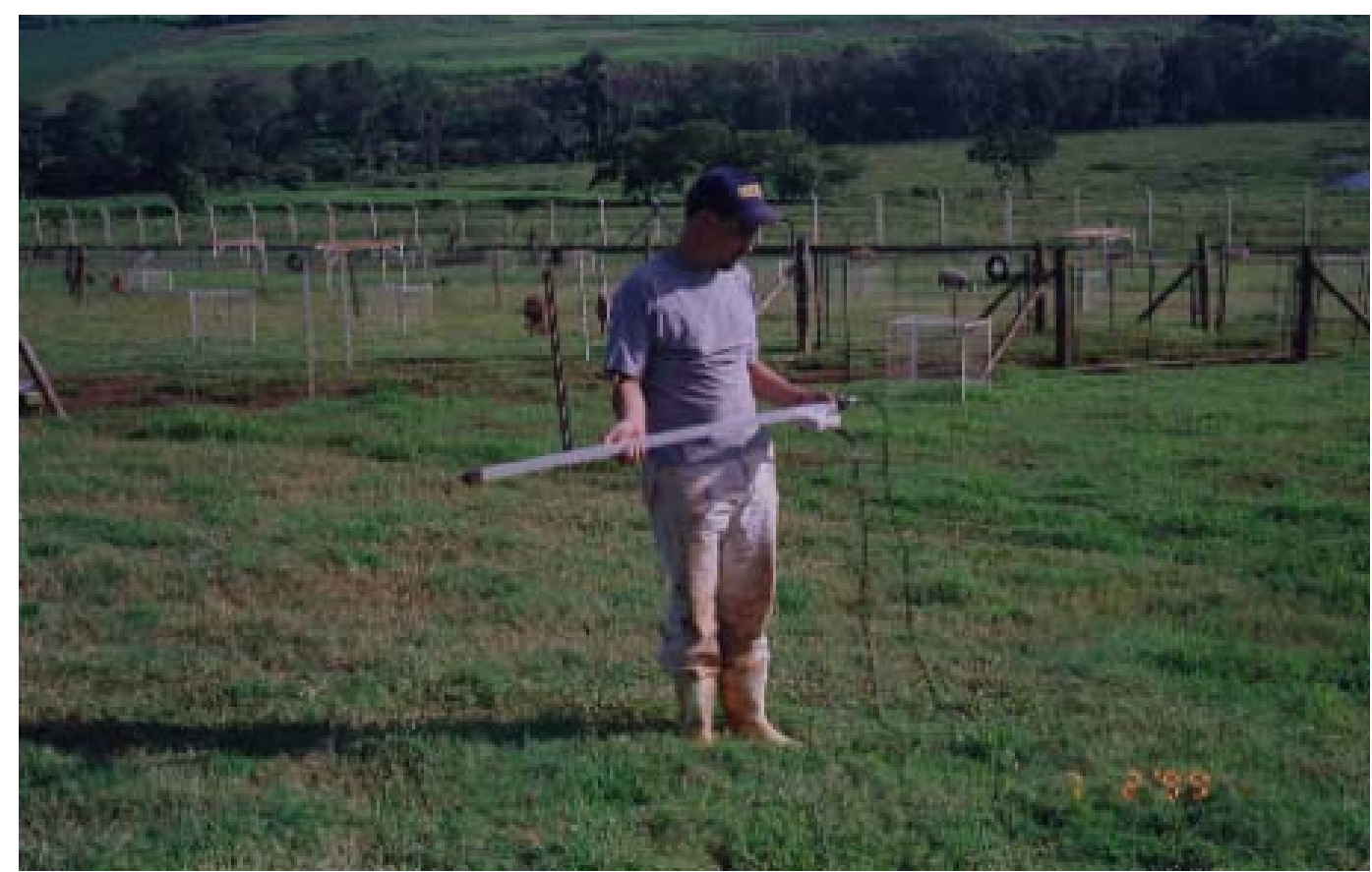

Foto 5 : Ilustração do fotômetro de barra utilizado nas avaliações de interceptação luminosa. 


\section{RESULTADOS E DISCUSSÃO}

Por ocasião da análise estatística, efetuou-se o desmembramento dos dados sempre que ocorreu interação significativa $(P<0,05)$ entre os fatores estudados.

\section{1 Índice de área foliar}

Os dados referentes ao índice de área foliar (IAF) são mostrados na Tabela 3 e Figuras 1 e 2 . Houve efeitos de mês ( $P=0,0001)$, cultivar $(P=0,0001)$ e mês $x$ cultivar $(P=0,0001)$ os quais podem ser observados na Tabela 3 e Figura 1. Houve efeito de altura $(P=0,0001))$ e pode ser observado na Tabela 3 e Figura 2 e de cultivar $x$ altura $(P=0,0357)$, observados na Tabela 3.

Madakadze et al. (1998) trabalhando com Panicum virgatum observaram diferenças na distribuição vertical de IAF entre as populações em ambos os anos de avaliação, havendo interação entre ano $x$ populações de Panicum $x$ altura. Resultados semelhantes foram encontrados neste ensaio, uma vez que ocorreram interações entre mês $x$ cultivar e cultivar $x$ altura.

Os valores de IAF encontrados no presente experimento variaram entre 0,21 e 3,71 (Tabela 3). Estes são valores bastante inferiores àqueles relatados por Brougham (1956 e 1957) para plantas de clima temperado, particularmente 
Tabela 3 - Índice de área foliar de julho a dezembro de 1998 para os tratamentos (Cultivar $\times$ Altura).

\begin{tabular}{|c|c|c|c|c|c|}
\hline Altura & Tifton 85 & Florakirk & Coastcross & média & EPM \\
\hline $\begin{array}{c}5 \\
10 \\
15 \\
20 \\
\text { média } \\
\text { EPM }\end{array}$ & $\begin{array}{c}1,20^{\mathrm{Ca}} \\
2,13^{\mathrm{Ba}} \\
2,74^{\mathrm{Ba}} \\
3,67^{\mathrm{Aa}} \\
2,44^{\mathrm{a}} \\
0,06\end{array}$ & $\begin{array}{c}0,78^{\mathrm{Ba}} \\
1,61^{\mathrm{Aab}} \\
1,71^{\mathrm{Ab}} \\
2,06^{\mathrm{Ab}} \\
1,54^{\mathrm{b}} \\
0,06 \\
\end{array}$ & $\begin{array}{c}\text { Julho } \\
0,86^{\mathrm{Ba}} \\
1,24^{\mathrm{ABb}} \\
1,40^{\mathrm{ABb}} \\
1,59^{\mathrm{Ab}} \\
1,27^{\mathrm{b}} \\
0,06 \\
\end{array}$ & $\begin{array}{l}0,95^{\mathrm{C}} \\
1,66^{\mathrm{B}} \\
1,95^{\mathrm{AB}} \\
2,44^{\mathrm{A}}\end{array}$ & $\begin{array}{l}0,07 \\
0,07 \\
0,07 \\
0,07\end{array}$ \\
\hline $\begin{array}{c}5 \\
10 \\
15 \\
20 \\
\text { média } \\
\text { EPM }\end{array}$ & $\begin{array}{c}0,84^{\mathrm{Da}} \\
1,68^{\mathrm{Ca}} \\
2,66^{\mathrm{Ba}} \\
3,71^{\mathrm{Aa}} \\
1,05^{\mathrm{a}} \\
0,14\end{array}$ & $\begin{array}{c}0,70^{\mathrm{Ba}} \\
1,47^{\mathrm{ABa}} \\
1,33^{\mathrm{ABb}} \\
2,04^{\mathrm{Ab}} \\
0,83^{\mathrm{b}} \\
0,14\end{array}$ & $\begin{array}{c}\text { Agosto } \\
0,50^{\mathrm{Ba}} \\
1,22^{\mathrm{ABa}} \\
1,00^{\mathrm{ABb}} \\
1,37^{\mathrm{Ab}} \\
1,93^{\mathrm{b}} \\
0,14\end{array}$ & $\begin{array}{l}0,68^{\mathrm{C}} \\
1,45^{\mathrm{B}} \\
1,67^{\mathrm{B}} \\
2,37^{\mathrm{A}}\end{array}$ & $\begin{array}{l}0,16 \\
0,16 \\
0,16 \\
0,16\end{array}$ \\
\hline $\begin{array}{c}5 \\
10 \\
15 \\
20 \\
\text { média } \\
\text { EPM }\end{array}$ & $\begin{array}{c}0,84^{\mathrm{Ca}} \\
1,02^{\mathrm{Ca}} \\
1,57^{\mathrm{Ba}} \\
2,67^{\mathrm{Aa}} \\
1,50^{\mathrm{a}} \\
0,11\end{array}$ & $\begin{array}{c}0,60^{\mathrm{Ba}} \\
0,75^{\mathrm{ABa}} \\
0,91^{\mathrm{ABb}} \\
1,08^{\mathrm{Ab}} \\
0,83^{\mathrm{b}} \\
0,11\end{array}$ & $\begin{array}{c}\text { Setembro } \\
0,21^{\mathrm{Aa}} \\
0,54^{\mathrm{Aa}} \\
0,66^{\mathrm{Ab}} \\
0,78^{\mathrm{Ab}} \\
0,55^{\mathrm{b}} \\
0,11^{4}\end{array}$ & $\begin{array}{c}0,51^{\mathrm{C}} \\
0,77^{\mathrm{BC}} \\
1,05^{\mathrm{B}} \\
1,51^{\mathrm{A}}\end{array}$ & $\begin{array}{l}0,13 \\
0,13 \\
0,13 \\
0,13\end{array}$ \\
\hline $\begin{array}{c}5 \\
10 \\
15 \\
20 \\
\text { média } \\
\text { EPM }\end{array}$ & $\begin{array}{c}1,27^{\mathrm{Ca}} \\
2,10^{\mathrm{Ba}} \\
2,19^{\mathrm{Ba}} \\
3,87^{\mathrm{Aa}} \\
2,36^{\mathrm{a}} \\
0,11\end{array}$ & $\begin{array}{c}1,13^{\mathrm{Ba}} \\
1,87^{\mathrm{ABa}} \\
2,12^{\mathrm{Aa}} \\
2,32^{\mathrm{Ab}} \\
1,86^{\mathrm{b}} \\
0,11^{\circ}\end{array}$ & $\begin{array}{c}\text { Outubro } \\
1,28 \\
1,75^{\mathrm{Aa}} \\
1,87^{\mathrm{Aa}} \\
1,79^{\mathrm{Ab}} \\
1,67^{\mathrm{b}} \\
0,11\end{array}$ & $\begin{array}{l}1,23^{\mathrm{C}} \\
1,91^{\mathrm{B}} \\
2,06^{\mathrm{B}} \\
2,65^{\mathrm{A}}\end{array}$ & $\begin{array}{l}0,13 \\
0,13 \\
0,13 \\
0,13\end{array}$ \\
\hline $\begin{array}{c}5 \\
10 \\
15 \\
20 \\
\text { média } \\
\text { EPM }\end{array}$ & $\begin{array}{c}0,89^{\mathrm{Ca}} \\
1,09^{\mathrm{BCa}} \\
1,51^{\mathrm{Ba}} \\
2,04^{\mathrm{Aa}} \\
1,38^{\mathrm{a}} \\
0,07\end{array}$ & $\begin{array}{c}0,77^{\mathrm{Aa}} \\
0,92^{\mathrm{Aa}} \\
1,01^{\mathrm{Ab}} \\
1,03^{\mathrm{Ab}} \\
0,93^{\mathrm{b}} \\
0,07\end{array}$ & $\begin{array}{c}\text { Novembro } \\
0,68^{\mathrm{Aa}} \\
1,07^{\mathrm{Aa}} \\
0,93^{\mathrm{Ab}} \\
1,05^{\mathrm{Ab}} \\
0,93^{\mathrm{b}} \\
0,07\end{array}$ & $\begin{array}{c}0,78^{\mathrm{C}} \\
1,03^{\mathrm{BC}} \\
1,15^{\mathrm{AB}} \\
1,37^{\mathrm{A}}\end{array}$ & $\begin{array}{l}0,08 \\
0,08 \\
0,08 \\
0,08\end{array}$ \\
\hline $\begin{array}{c}5 \\
10 \\
15 \\
20 \\
\text { média } \\
\text { EPM }\end{array}$ & $\begin{array}{c}0,59^{\mathrm{Ba}} \\
1,16^{\mathrm{Aa}} \\
0,97^{\mathrm{ABa}} \\
1,47^{\mathrm{Aa}} \\
1,05^{\mathrm{a}} \\
0,093\end{array}$ & $\begin{array}{c}0,49^{\mathrm{Ba}} \\
0,69^{\mathrm{Ba}} \\
1,40^{\mathrm{Aa}} \\
0,74^{\mathrm{Bb}} \\
0,83^{\mathrm{a}} \\
0,093^{3}\end{array}$ & $\begin{array}{c}\text { Dezembro } \\
0,66 \\
0,85^{\mathrm{Aa}} \\
1,11^{\mathrm{Aa}} \\
1,09^{\mathrm{Aab}} \\
1,93^{\mathrm{a}} \\
0,093\end{array}$ & $\begin{array}{c}0,58^{\mathrm{B}} \\
0,90^{\mathrm{AB}} \\
1,16^{\mathrm{A}} \\
1,10^{\mathrm{A}}\end{array}$ & $\begin{array}{l}0,11 \\
0,11 \\
0,11 \\
0,11\end{array}$ \\
\hline
\end{tabular}




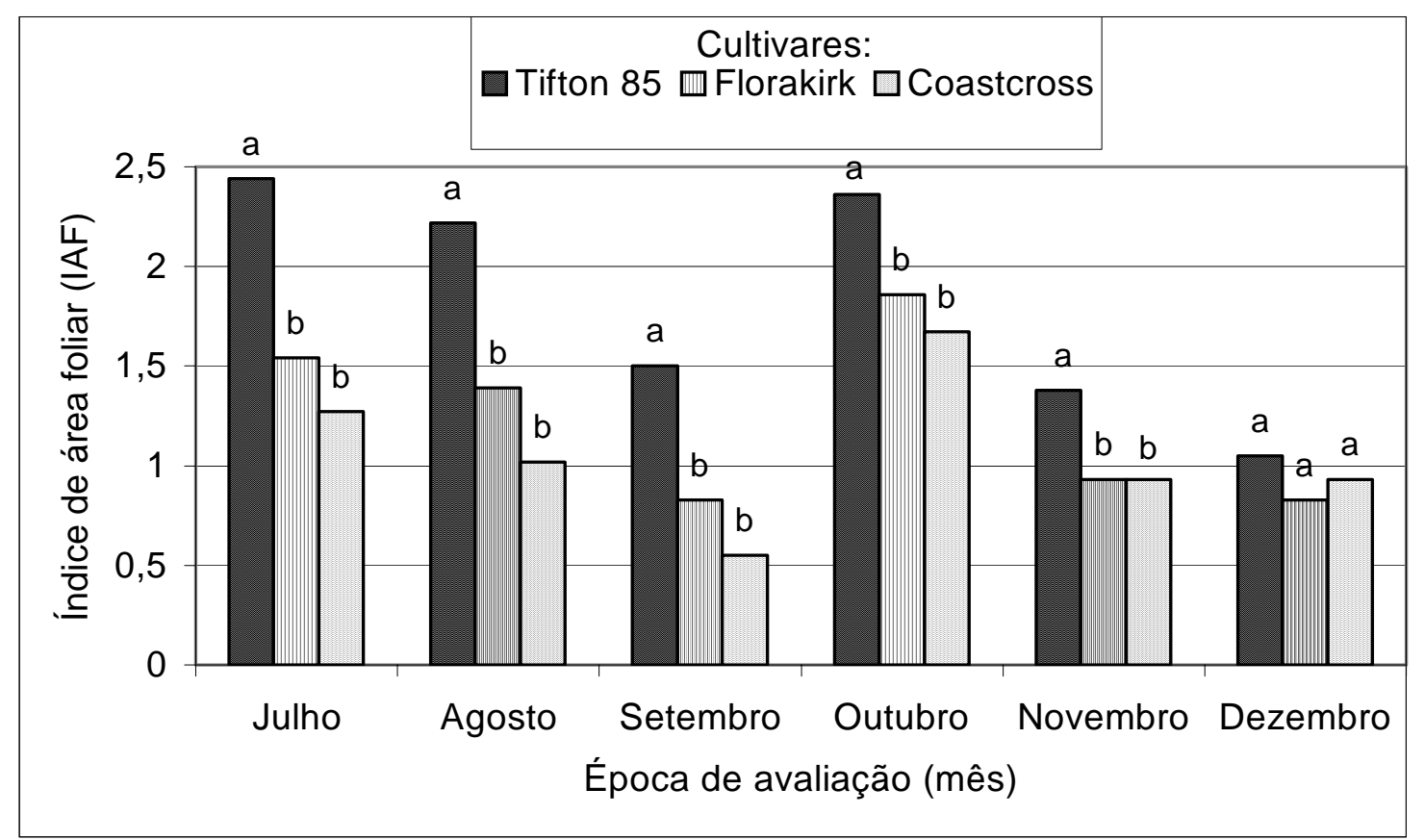

Figura 1 - Índice de área foliar em cultivares de Cynodon spp. sob regime de lotação contínua e em diferentes épocas de avaliação.

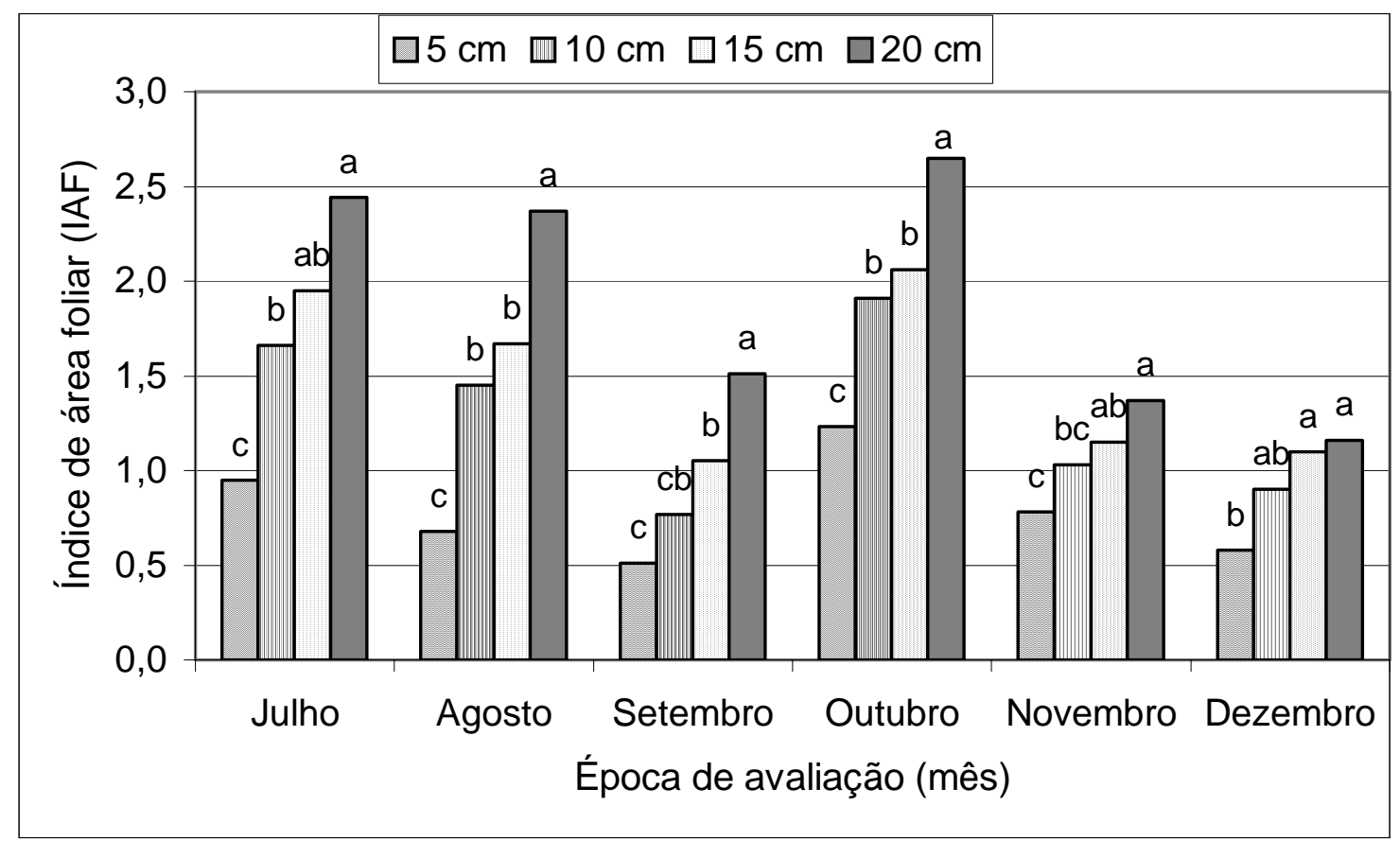

Figura 2 - Índice de área foliar em cultivares de Cynodon spp. sob diferentes intensidades de pastejo em regime de lotação contínua avaliados em diferentes épocas do ano. 
azevém perene. Esse autor relatou que 95\% de interceptação de luz foi obtida com um IAF igual a 5,0 e 3,5 para azevém perene e trevo branco, respectivamente.

Ensaio conduzido por Clapp Jr. et al. (1965) revelou valores de IAF entre 1,4 e 2,7 para Cynodon dactylon cv Coastal, semelhantes aos obtidos neste ensaio. Em trabalho mais recente, Gomide (1996) observou, em diferentes idades de crescimento, valor mínimo e máximo de IAF de 1,68 e 5,85 para Tifton 85 e 1,19 e 5,89 para Florakirk, avaliados aos 14 e 42 dias, respectivamente.

Os valores de IAF ótimo variam de 2 a 3 até valores maiores que 15 conforme a espécie (Brougham, 1957; Mott \& Popenoe, 1977), e existem também grandes diferenças entre cultivares dentro de espécies, o que suporta os resultados obtidos neste trabalho.

Mott \& Popenoe (1977) citaram que algumas linhagens de Pennisetum purpureum e Panicum maximum têm folhas dispostas mais verticalmente durante grande parte de seu crescimento, o que Ihes permite apresentar elevados valores de IAF e alta eficiência de IL em comunidades vegetais. Outros gêneros como Cynodon, Digitaria e Bachiaria têm folhas orientadas mais horizontalmente e apresentam menores valores de IAF.

Tifton 85 apresentou IAF consistentemente mais elevado que Florakirk e esta, por sua vez, não diferiu de Coastcross (Tabela 3 e Figura 1). As diferenças entre cultivares refletem a história evolutiva da população, seja adquirida naturalmente ou através de programas de melhoramento e seleção deliberados (Cooper, 1983; Madakadze et al. 1998). Os maiores valores de IAF do Tifton 85 devem estar associados com seu porte mais alto, com hastes grandes, folhas mais largas e compridas, de côr verde mais escura que os outros híbridos (Burton et al.,1993).

Conforme esperado, pastos mantidos mais altos apresentaram os maiores valores de IAF (Tabela 3 e Figura 2), corroborando os resultados encontrados por Clapp Jr. et al. (1965) e Clavero Cepeda (1993b). 
Os baixos valores de IAF encontrados nos meses de novembro e dezembro podem ter sido causados pela ocorrência de um período de estiagem bastante severo, com valores pluviométricos para o mês de novembro correspondentes à média mais baixa dos últimos 40 anos (26,8 vs 150 mm) (ESALQ, 1999).

A interação entre cultivar e intensidade de pastejo para o IAF durante o período experimental é ilustrada pela mudança no ranqueamento dos valores de IAF entre os cultivares para as intensidades de pastejo. Ou seja, até o mês de outubro, para as maiores intensidades de pastejo $(5$ e $10 \mathrm{~cm})$, os maiores valores de IAF foram apresentados por Tifton 85 seguidos de Florakirk e Coastcross. A partir de novembro, os valores de IAF da Florakirk foram igualados e superados pelo Coastcross, exceção feita para a intensidade de pastejo de $15 \mathrm{~cm}$ no mês de dezembro.

Estas diferenças devem-se ao fato de que durante o período de avaliação, particularmente de agosto a novembro, os cultivares Florakirk e Coastcross apresentaram desenvolvimento reprodutivo (florescimento) bastante intenso e contínuo, principalmente nas maiores alturas de pastejo, o que deve ter sido responsável por variações na estrutura do pasto (e.g. material morto, material vivo) relacionadas com mudanças nas proporções de haste e folha na forragem. Humphreys (1966b) mencionou que Panicum maximum var trichoglume também apresentou um florescimento mais avançado em pastos pastejados lenientemente e quando limitações de umidade foram aparentes. De acordo com esse autor, o grau de florescimento foi negativamente relacionado à intensidade de desfolha, e as diferenças nos valores de IAF, induzidas pelas desfolhas, foram afetadas pelo florescimento.

Segundo Cooper (1983) as diferenças relatadas entre e dentro de espécies forrageiras devem-se a algumas características do dossel do pasto como tamanho de folha, ângulo de inserção entre a folha e o caule, rigidez das folhas, etc., que podem afetar a sua estrutura e, consequentemente, o IAF, a IL e a taxa de acúmulo de matéria seca. 


\subsection{Interceptação luminosa}

Os dados referentes a interceptação luminosa (IL) são mostrados na Tabela 4 e nas Figuras 3 e 4 . Houve efeito de mês $(P=0,0001)$, cultivar $(P=0,0001)$ e mês $x$ cultivar $(P=0,0001)$ os quais podem ser observados na Tabela 4 e Figura 3. Houve também efeito de altura $(P=0,0001)$ e mês $x$ altura $(P=0,001)$ os quais podem ser observados na Tabela 4 e Figura 4 e cultivar $x$ altura $(P=0,0003)$ observado na Tabela 4.

Coastcross apresentou menores valores de IL que Florakirk e Tifton 85 (Tabela 4 e Figura 3). Isto é consistente com as variações em IAF observados (Tabela 3 e Figura 1) e reflete, provavelmente, as diferenças morfológicas dos cultivares em estudo. Vale salientar que nos meses de novembro e dezembro os valores de IL sofreram uma diminuição, o que pode ser parcialmente explicado pelos baixos valores de IAF observados neste período. Madakadze et al. (1998) também apontaram uma íntima relação entre IL e IAF, com aumentos em IAF resultando em aumento da IL.

Pastos mantidos mais altos apresentaram os maiores valores de IL. Com o avanço da estação de crescimento foi observado uma estabilização nas diferenças entre as intensidades de pastejo, ou seja, a partir do mês de setembro as diferenças relativas entre tratamentos mantiveram-se mais ou menos constantes.

Quando o dossel intercepta 95\% da luz incidente tem-se um valor de IAF dito crítico no qual a taxa de crescimento da cultura está próxima de um valor máximo (Brougham, 1956; Brougham, 1957; Watson, 1958; Brown \& Blaser, 1968; Rhodes, 1973; Hay \& Walker, 1989). Segundo essa premissa somente o cultivar Tifton 85, especialmente na menor intensidade de pastejo (20 cm), atingiu as condições necessárias para alcançar essa taxa de crescimento máximo, uma vez que foi o único tratamento capaz de interceptar 95\% da luz incidente. 
Tabela 4 - Interceptação luminosa (\%) de julho a dezembro de 1998 para os tratamentos (Cultivar x Altura) experimentais.

\begin{tabular}{|c|c|c|c|c|c|}
\hline Altura & Tifton 85 & Florakirk & Coastcross & média & EPM \\
\hline $\begin{array}{c}5 \\
10 \\
15 \\
20 \\
\text { média } \\
\text { EPM } \\
\end{array}$ & $\begin{array}{c}20,2^{\mathrm{Ca}} \\
80,7^{\mathrm{Ba}} \\
94,3^{\mathrm{Aa}} \\
97,8^{\mathrm{Aa}} \\
73,5^{\mathrm{a}} \\
1,87^{-}\end{array}$ & $\begin{array}{l}24,6^{\mathrm{Ca}} \\
73,1^{\mathrm{Bb}} \\
92,8^{\mathrm{Aa}} \\
94,2^{\mathrm{Aa}} \\
71,2^{\mathrm{ab}} \\
1,87 \\
\end{array}$ & $\begin{array}{c}\text { Julho } \\
30,1^{\mathrm{Da}} \\
63,8^{\mathrm{Cb}} \\
79,0^{\mathrm{Bb}} \\
89,9^{\mathrm{Aa}} \\
65,7^{\mathrm{b}} \\
1,87 \\
\end{array}$ & $\begin{array}{c}25,3^{\mathrm{C}} \\
72,5^{\mathrm{B}} \\
88,7^{\mathrm{A}} \\
94,0^{\mathrm{A}}\end{array}$ & $\begin{array}{l}2,16 \\
2,16 \\
2,16 \\
2,16\end{array}$ \\
\hline $\begin{array}{c}5 \\
10 \\
15 \\
20 \\
\text { média } \\
\text { EPM } \\
\end{array}$ & $\begin{array}{c}31,2^{\mathrm{Cab}} \\
74,5^{\mathrm{Ba}} \\
92,1^{\mathrm{Aa}} \\
97,2^{\mathrm{Aa}} \\
74,5^{\mathrm{a}} \\
1,61 \\
\end{array}$ & $\begin{array}{c}29,5^{\mathrm{Ca}} \\
70,3^{\mathrm{Ba}} \\
85,7^{\mathrm{Aa}} \\
91,8^{\mathrm{Aa}} \\
72,2^{\mathrm{a}} \\
1,61 \\
\end{array}$ & $\begin{array}{c}\text { Agosto } \\
25,2^{\mathrm{Db}} \\
50,0^{\mathrm{Cb}} \\
66,9^{\mathrm{Bb}} \\
81,6^{\mathrm{Ab}} \\
59,8^{\mathrm{b}} \\
1,61 \\
\end{array}$ & $\begin{array}{l}34,1^{\mathrm{C}} \\
64,5^{\mathrm{B}} \\
85,0^{\mathrm{A}} \\
91,8^{\mathrm{A}}\end{array}$ & $\begin{array}{l}1,85 \\
1,85 \\
1,85 \\
1,85\end{array}$ \\
\hline $\begin{array}{c}5 \\
10 \\
15 \\
20 \\
\text { média } \\
\text { EPM }\end{array}$ & $\begin{array}{c}36,6^{\mathrm{Ca}} \\
70,7^{\mathrm{Ba}} \\
93,2^{\mathrm{Aa}} \\
97,4^{\mathrm{Aa}} \\
73,8^{\mathrm{a}} \\
1,36\end{array}$ & $\begin{array}{c}38,1^{\mathrm{Ca}} \\
67,2^{\mathrm{Ba}} \\
89,8^{\mathrm{Aa}} \\
93,7^{\mathrm{Aa}} \\
69,3^{\mathrm{a}} \\
1,36\end{array}$ & $\begin{array}{c}\text { Setembro }^{\mathrm{Da}} \\
27,5^{\mathrm{Da}} \\
55,5^{\mathrm{Cb}} \\
71,8^{\mathrm{Bb}} \\
84,3^{\mathrm{Ab}} \\
55,9^{\mathrm{b}} \\
1,36\end{array}$ & $\begin{array}{c}28,61^{\mathrm{D}} \\
65,0^{\mathrm{C}} \\
81,6^{\mathrm{B}} \\
90,2^{\mathrm{A}}\end{array}$ & $\begin{array}{l}1,57 \\
1,57 \\
1,57 \\
1,57\end{array}$ \\
\hline $\begin{array}{c}5 \\
10 \\
15 \\
20 \\
\text { média } \\
\text { EPM }\end{array}$ & $\begin{array}{c}27,1^{\mathrm{Ca}} \\
72,6^{\mathrm{Ba}} \\
91,1^{\mathrm{Aa}} \\
95,7^{\mathrm{Aa}} \\
71,6^{\mathrm{a}} \\
0,93\end{array}$ & $\begin{array}{c}26,3^{\mathrm{Cb}} \\
70,1^{\mathrm{Ba}} \\
88,3^{\mathrm{Aa}} \\
93,4^{\mathrm{Aa}} \\
69,5^{\mathrm{a}} \\
0,93\end{array}$ & $\begin{array}{c}\text { Outubro } \\
23,6^{\mathrm{Dc}} \\
56,5^{\mathrm{Cb}} \\
78,1^{\mathrm{Bb}} \\
86,7^{\mathrm{Ab}} \\
61,2^{\mathrm{b}} \\
0,93\end{array}$ & $\begin{array}{l}25,7^{\mathrm{D}} \\
66,4^{\mathrm{C}} \\
85,8^{\mathrm{B}} \\
91,9^{\mathrm{A}}\end{array}$ & $\begin{array}{l}1,07 \\
1,07 \\
1,07 \\
1,07\end{array}$ \\
\hline $\begin{array}{c}5 \\
10 \\
15 \\
20 \\
\text { média } \\
\text { EPM } \\
\end{array}$ & $\begin{array}{c}26,7^{\mathrm{Ca}} \\
68,5^{\mathrm{Ba}} \\
91,2^{\mathrm{Aa}} \\
96,1^{\mathrm{Aa}} \\
70,7^{\mathrm{a}} \\
1,29 \\
\end{array}$ & $\begin{array}{c}22,4^{\mathrm{Db}} \\
54,5^{\mathrm{Cb}} \\
79,5^{\mathrm{Bb}} \\
90,9^{\mathrm{Ab}} \\
61,8^{\mathrm{b}} \\
1,29 \\
\end{array}$ & $\begin{array}{c}\text { Novembro } \\
19,0^{\mathrm{Dc}} \\
43,2^{\mathrm{Cc}} \\
71,2^{\mathrm{Bc}} \\
82,8^{\mathrm{Ac}} \\
54,1^{\mathrm{C}} \\
1,29 \\
\end{array}$ & $\begin{array}{l}22,7^{\mathrm{D}} \\
55,4^{\mathrm{C}} \\
80,6^{\mathrm{B}} \\
89,9^{\mathrm{A}}\end{array}$ & $\begin{array}{l}1,49 \\
1,49 \\
1,49 \\
1,49\end{array}$ \\
\hline $\begin{array}{c}5 \\
10 \\
15 \\
20 \\
\text { média } \\
\text { EPM }\end{array}$ & $\begin{array}{c}3,7^{\mathrm{Ca}} \\
41,3^{\mathrm{Ba}} \\
87,2^{\mathrm{Aa}} \\
93,3^{\mathrm{Aa}} \\
56,4^{\mathrm{a}} \\
1,38\end{array}$ & $\begin{array}{c}4,7^{\mathrm{Da}} \\
29,6^{\mathrm{Cc}} \\
78,5^{\mathrm{Bb}} \\
89,0^{\mathrm{Aa}} \\
50,5^{\mathrm{b}} \\
1,38\end{array}$ & $\begin{array}{c}\text { Dezembro } \\
5,3^{\mathrm{Da}} \\
38,1^{\mathrm{Cb}} \\
72,0^{\mathrm{Bb}} \\
86,3^{\mathrm{Aa}} \\
50,4^{\mathrm{b}} \\
1,38\end{array}$ & $\begin{array}{l}4,5^{\mathrm{D}} \\
36,4^{\mathrm{C}} \\
79,2^{\mathrm{B}} \\
89,5^{\mathrm{A}}\end{array}$ & $\begin{array}{l}1,59 \\
1,59 \\
1,59 \\
1,59\end{array}$ \\
\hline
\end{tabular}

Médias na mesma coluna seguidas da mesma letra maiúscula e na mesma linha seguidas da mesma letra minúscula são iguais $(P>0,05)$. 


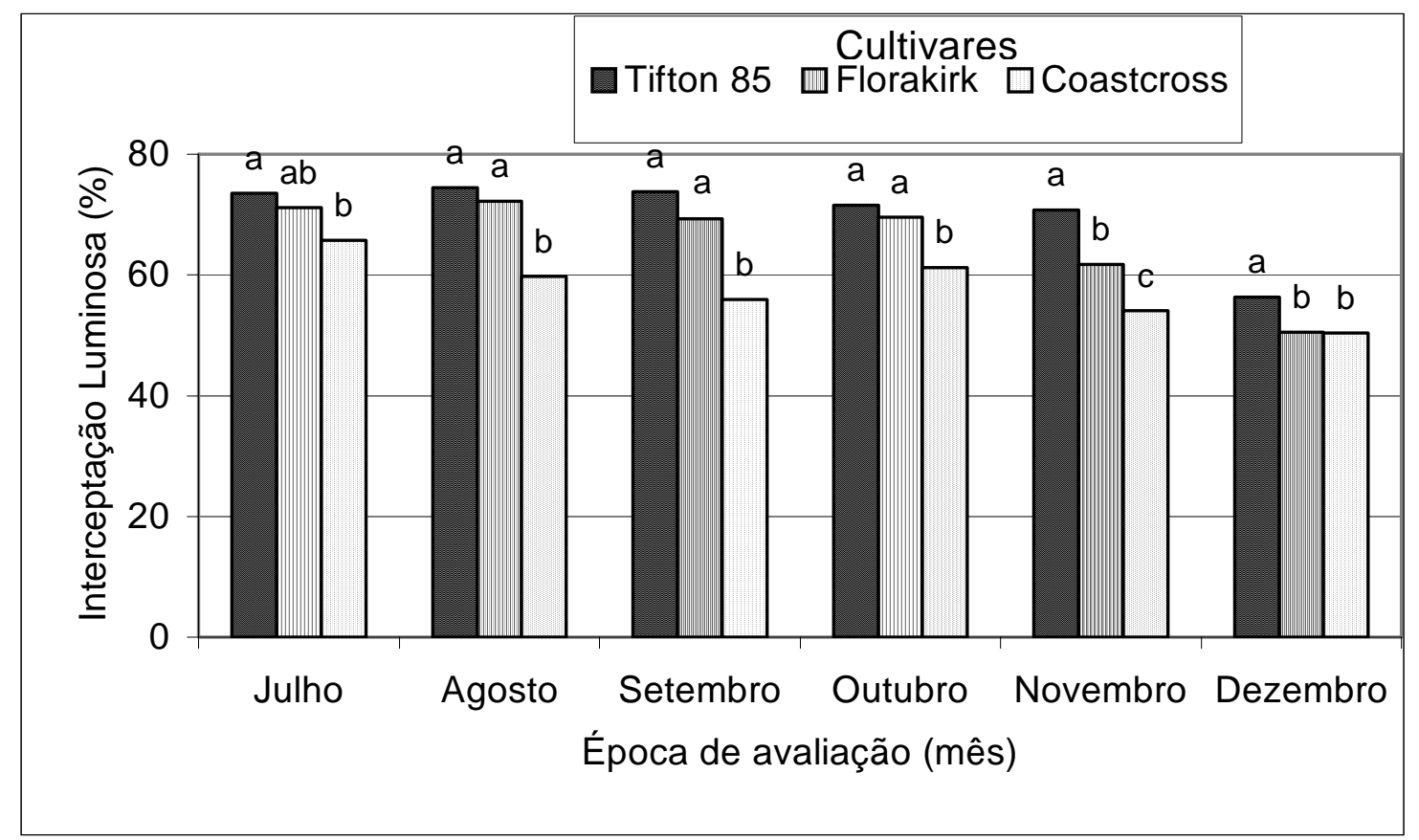

Figura 3 - Interceptação luminosa em cultivares de Cynodon spp. sob regime de lotação contínua e em diferentes épocas de avaliação.

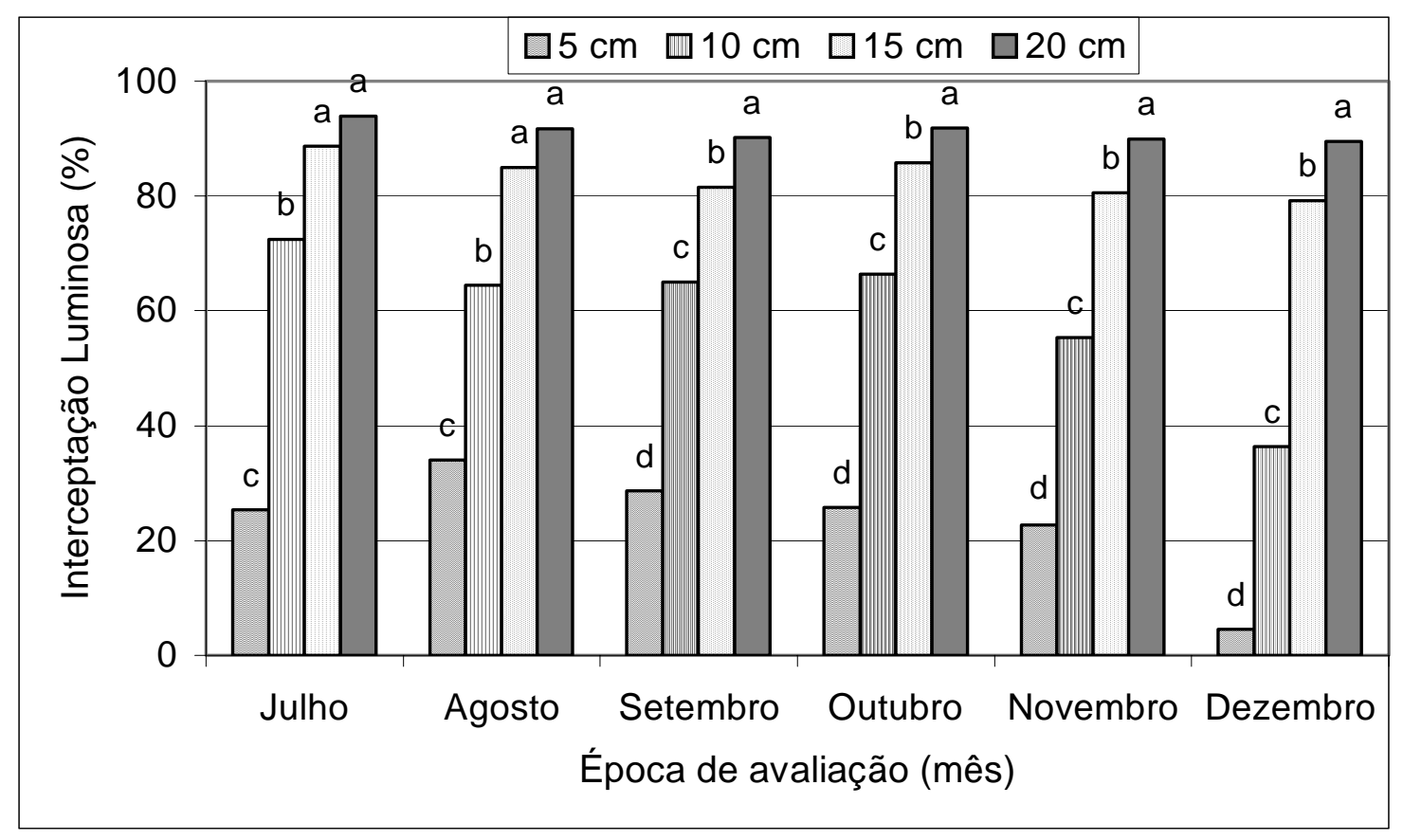

Figura 4 - Interceptação luminosa em cultivares de Cynodon spp. sob diferentes intensidades de pastejo em regime de lotação continua avaliados em diferentes épocas do ano. 
Contudo, devido a outros fatores ambientais limitantes como baixo índice pluviométrico, particularmente em novembro, é provável que essa taxa não tenha sido alcançada. Vale ressaltar que, tomando-se por base o critério de 95\% de interceptação luminosa como condição ótima para regulação de uso e colheita da planta, Tifton 85 estaria apta a ser colhida já a partir de $15 \mathrm{~cm}$. Coastcross, por sua vez, foi a que apresentou os menores valores de IL, mesmo na altura de $20 \mathrm{~cm}$, valores estes muito inferiores aos 95\% considerados ideais. Florakirk apresentou comportamento intermediário.

Observação mais cuidadosa da Tabela 4 revela que na condição de desfolha mais extrema $(5 \mathrm{~cm})$ o cultivar Tifton 85 interceptou, consistentemente, mais luz que as demais. Assim poderia-se inferir que Tifton 85 apresentaria uma flexibilidade, em termos de amplitude de altura de colheita, menor que Florakirk e Coastcross, uma vez que interceptou 95\% da luz incidente já a partir de $15 \mathrm{~cm}$ de altura enquanto que Florakirk e Coastcross provavelmente atingiriam esse ponto em altura superior a $20 \mathrm{~cm}$.

Valores disponíveis na literatura em trabalhos que relacionam IAF e IL mostram que o IAF crítico, onde 95\% da luz incidente é interceptado, seria de aproximadamente 5,0 (Brougham, 1956). Os valores obtidos para Tifton 85 no presente trabalho foram, em média, de 2,5. Clapp Jr. et al. (1965) para Cynodon dactylon cv Coastal, em ensaio conduzido no Estado da Carolina do Norte, nos Estados Unidos, encontrou valores de 1,4 a 2,7, similares ao deste experimento.

Provavelmente os valores de IL na altura de pastejo de $5 \mathrm{~cm}$ tenham sido subestimados, pois a leitura da radiação solar fotossinteticamente ativa acima do dossel e ao nível do solo, era realizada através de um equipamento (fotômetro de barra) que possui lente para leitura a 2,8 $\mathrm{cm}$ do nível do solo (Foto 4), o que poderia estar gerando um erro consistentemente maior para a intensidade de pastejo de $5 \mathrm{~cm}$ relativamente às demais alturas. Brougham (1957) relata ter omitido valores de leituras de IL e IAF em seu estudo porque o equipamento utilizado para mensurações de IL tendeu a deslocar as folhas e 
acabou por subestimar esses valores nos estádios iniciais de desenvolvimento das plantas. Esse efeito foi negligenciável quando as plantas atingiram estádios mais avançados de crescimento.

Verifica-se que ocorreu interação entre cultivar e intensidade de pastejo para a IL ilustrada pela alteração no ranqueamento dos cultivares ocorrido em dezembro na intensidade de pastejo de $10 \mathrm{~cm}$, ou seja, a IL no cultivar Florakirk foi inferior aos demais cultivares, comportamento inverso àquele observado durante os demais meses e intensidades de pastejo.

Sheehy \& Cooper (1973), Cooper (1983) e Humphreys (1991) mencionaram que a principal variável climática determinante da produção é a quantidade de energia luminosa incidente mas, na maioria dos ambientes de pastagens, o crescimento, ou até mesmo a sobrevivência das plantas, podem ser limitados por estresse térmico, hídrico ou nutricional. Durante o presente experimento foram verificadas baixas precipitações pluviométricas no mês de novembro, o que reduziu o crescimento de todos os cultivares de Cynodon, em especial Florakirk, que teve seu crescimento prejudicado nas maiores intensidades de pastejo durante os meses de novembro e dezembro. Isto pode ser verificado pelos baixos valores de IAF e IL na intensidade de pastejo de 10 $\mathrm{cm}$.

\subsection{Coeficiente de extinção luminosa}

Os valores de coeficiente de extinção luminosa $(k)$ são mostrados nas Tabelas 5 e 6 e nas Figuras 5 e 6 . Foram detectados efeitos de mês ( $P=0,0006)$ e cultivar $(P=0,002)$ (Tabela 5, Figura 5). Efeito de altura $(P=0,0001)$ e da interação mês $x$ altura $(P=0,004)$ são ilustrados na Tabela 6 e Figura 6 .

Diferenças nos valores de $k$ entre espécies ou cultivares de plantas são atribuídos à variação na distribuição e ângulos das folhas, sendo essas os principais órgãos responsáveis pela IL. Os valores de $k$ encontrados no 
presente experimento variaram entre 0,35 e 2,44 (Tabela 6). A maior parte dos trabalhos relata que os valores de $\mathrm{k}$ variam entre 0 e 1 (Sheehy \& Cooper, 1973; Hay \& Walker, 1989; Madakadze et al., 1998). Valores de k maiores que 1 foram encontrados por Siddique et al. (1989) e por Yunusa et al. (1993) em trigo var. Kulin, os quais foram 1,33 e 2,20 respectivamente.

Tabela 5 - Coeficiente de extinção luminosa de julho a dezembro de 1998 para os cultivares de Cynodon spp..

\begin{tabular}{ccccc}
\hline Mês & Tifton 85 & Florakirk & Coastcross & EPM \\
\hline Julho & $0,88^{\mathrm{a}}$ & $1,13^{\mathrm{a}}$ & $1,00^{\mathrm{a}}$ & 0,09 \\
Agosto & $0,83^{\mathrm{b}}$ & $1,11^{\mathrm{a}}$ & $0,83^{\mathrm{b}}$ & 0,07 \\
Setembro & $0,78^{\mathrm{ab}}$ & $0,97^{\mathrm{a}}$ & $0,74^{\mathrm{b}}$ & 0,06 \\
Outubro & $0,73^{\mathrm{a}}$ & $0,99^{\mathrm{a}}$ & $0,89^{\mathrm{a}}$ & 0,06 \\
Novembro & $1,27^{\mathrm{a}}$ & $1,58^{\mathrm{a}}$ & $1,29^{\mathrm{a}}$ & 0,15 \\
Dezembro & $1,23^{\mathrm{a}}$ & $1,50^{\mathrm{a}}$ & $1,03^{\mathrm{a}}$ & 0,18 \\
\hline Médias na mesma linha seguidas da mesma letra minúscula são iguais (P>0,05). & EPM - erro padrão da média.
\end{tabular}

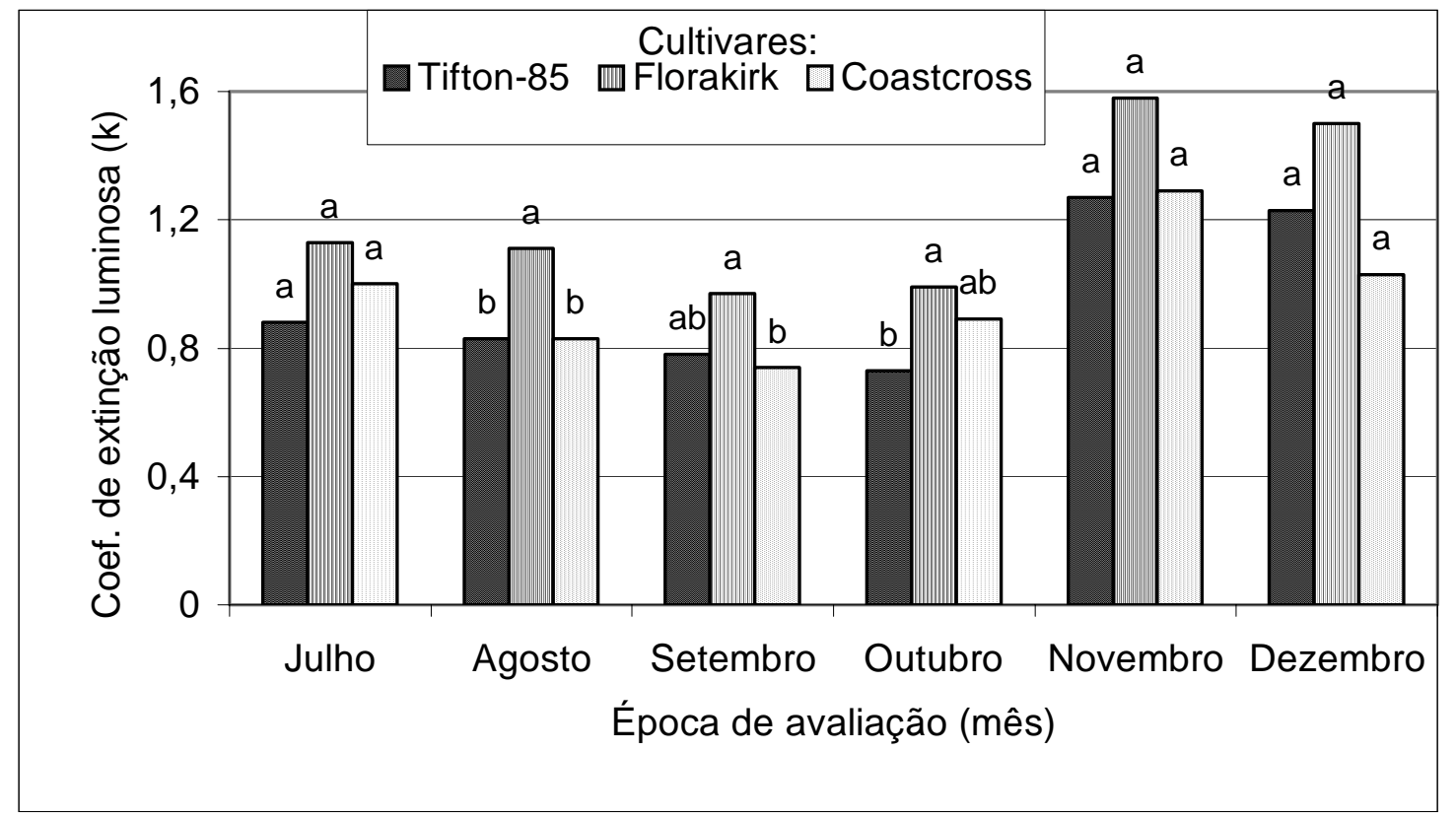

Figura 5 - Coeficiente de extinção luminosa em cultivares de Cynodon spp. sob regime de lotação contínua e em diferentes épocas de avaliação. 
Tabela 6 - Coeficiente de extinção luminosa de julho a dezembro de 1998 para as alturas de pastejo em estudo.

\begin{tabular}{cccccc}
\hline Mês & $\mathbf{5 ~} \mathbf{~ c m}$ & $\mathbf{1 0} \mathbf{~ c m}$ & $\mathbf{1 5} \mathbf{~ c m}$ & $\mathbf{2 0} \mathbf{~ c m}$ & EPM \\
\hline Julho & $0,38^{\mathrm{c}}$ & $0,94^{\mathrm{b}}$ & $1,30^{\mathrm{ab}}$ & $1,40^{\mathrm{a}}$ & 0,11 \\
Agosto & $0,51^{\mathrm{b}}$ & $0,75^{\mathrm{b}}$ & $1,14^{\mathrm{a}}$ & $1,29^{\mathrm{a}}$ & 0,08 \\
Setembro & $0,40^{\mathrm{c}}$ & $0,74^{\mathrm{b}}$ & $1,01^{\mathrm{a}}$ & $1,17^{\mathrm{a}}$ & 0,07 \\
Outubro & $0,35^{\mathrm{c}}$ & $0,76^{\mathrm{b}}$ & $1,12^{\mathrm{a}}$ & $1,25^{\mathrm{a}}$ & 0,07 \\
Novembro & $0,45^{\mathrm{c}}$ & $1,08^{\mathrm{cb}}$ & $1,75^{\mathrm{ab}}$ & $2,23^{\mathrm{a}}$ & 0,18 \\
Dezembro & $0,11^{\mathrm{b}}$ & $0,55^{\mathrm{b}}$ & $1,91^{\mathrm{a}}$ & $2,44^{\mathrm{a}}$ & 0,21 \\
\hline Médias na mesma linha seguidas da mesma letra minúscula são iguais $(\mathrm{P}>0,05)$. & EPM - erro padrão da média.
\end{tabular}

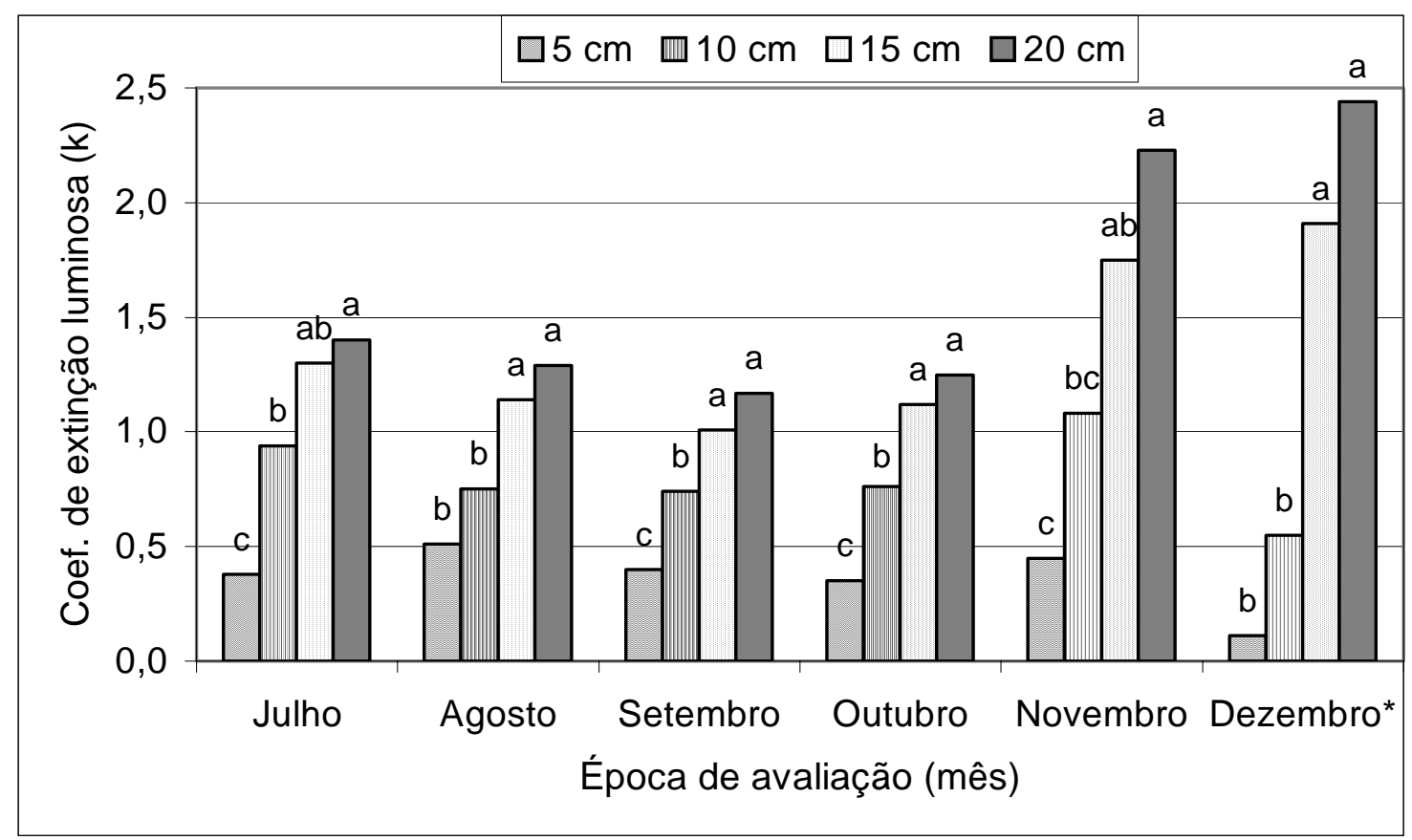

Figura 6 - Coeficiente de extinção luminosa em cultivares de Cynodon spp. sob diferentes intensidades de pastejo e regime de lotação contínua, avaliados em diferentes épocas do ano.

Szeicz (1974) argumentou que o espectro da radiação também pode determinar o valor de $\mathrm{k}$. Para a maioria das culturas o $\mathrm{k}$ baseado na radiação fotossinteticamente ativa (PAR), $k_{p}$, sempre é maior que o $k$ determinado com a radiação solar total $\left(\mathrm{k}_{\mathrm{T}}\right)$, sugerindo maior atenuação de PAR dentro do dossel 
quando comparado à radiação solar total. Yunusa et al. (1993), com cultivares de trigo, compararam $\mathrm{k}_{\mathrm{P}}$ e $\mathrm{k}_{\mathrm{T}}$ verificando que para todos os cultivares os valores médios de $\mathrm{k}_{\mathrm{T}}$ foi aproximadamente $30 \%$ menor que os valores médios de $\mathrm{k}_{\mathrm{P}}$ na mesma estação.

Florakirk apresentou um $\mathrm{k}$ consistentemente mais elevado que Tifton 85 e Coastcross (Tabela 5 e Figura 5), demonstrando que este cultivar tem uma tendência a ter uma arquitetura foliar mais horizontal (planófilo). Siddique et al. (1989) e Yunusa et al. (1993) descrevem que um valor mais elevado de k pode ser atribuído à distribuição mais uniforme da área foliar e à arquitetura mais plana do dossel. Yunusa et al. (1993) evidenciam que os valores de k diferem entre cultivares dentro da estação de crescimento e diferem no mesmo cultivar durante a mesma estação de crescimento, corroborando os resultados obtidos no presente estudo (Tabela 5).

Pastos mantidos mais altos apresentaram os maiores valores de $\mathrm{k}$, o que provavelmente esta associado a folhas maiores e mais horizontais diminuindo a quantidade de luz propagada ao longo do perfil do pasto (Tabela 6 e Figura 6).

A partir do mês de novembro os valores observados de $k$ foram mais elevados, provavelmente devido à redução drástica do desenvolvimento reprodutivo nos pastos, indicando potenciais mudanças em uma arquitetura e composição botânica/morfológica.

\subsection{Taxa de acúmulo de forragem}

Os dados referentes ao acúmulo de forragem são mostrados na Tabelas 7 e 8 e Figuras 7 e 8 . Houve diferenças apenas entre mês ( $P=0,0001)$ as quais podem ser observados nas Figuras 7 e 8 .

Uma característica dos dados é um comportamento relativamente constante para as taxas de acúmulo de forragem com o decorrer da estação de crescimento. Em novembro e dezembro valores inferiores aos de outubro foram 
observados, provavelmente como conseqüência dos baixos índices pluviométricos ocorridos (Tabela 2), muito embora estes valores tenham sido superiores aos apresentados durante os meses de agosto e setembro.

Tabela 7 - Taxas de acúmulo de matéria seca $\left(\mathrm{kg} \mathrm{MS} \mathrm{ha}^{-1} \mathrm{dia}^{-1}\right)$ de agosto a dezembro de 1998 para os cultivares de Cynodon spp..

\begin{tabular}{ccccc}
\hline Mês & Tifton 85 & Florakirk & Coastcross & EPM \\
\hline Agosto & $30,4^{\mathrm{a}}$ & $38,9^{\mathrm{a}}$ & $41,4^{\mathrm{a}}$ & 3,82 \\
Setembro & $25,3^{\mathrm{b}}$ & $23,9^{\mathrm{b}}$ & $34,0^{\mathrm{a}}$ & 2,03 \\
Outubro & $54,1^{\mathrm{a}}$ & $49,9^{\mathrm{a}}$ & $63,3^{\mathrm{a}}$ & 5,84 \\
Novembro & $49,4^{\mathrm{a}}$ & $35,9^{\mathrm{a}}$ & $49,0^{\mathrm{a}}$ & 4,78 \\
Dezembro & $48,9^{\mathrm{a}}$ & $49,6^{\mathrm{a}}$ & $53,7^{\mathrm{a}}$ & 6,03 \\
\hline Médias na mesma linha seguidas da mesma letra minúscula são iguais (P>0,05). & EPM - erro padrão da média.
\end{tabular}

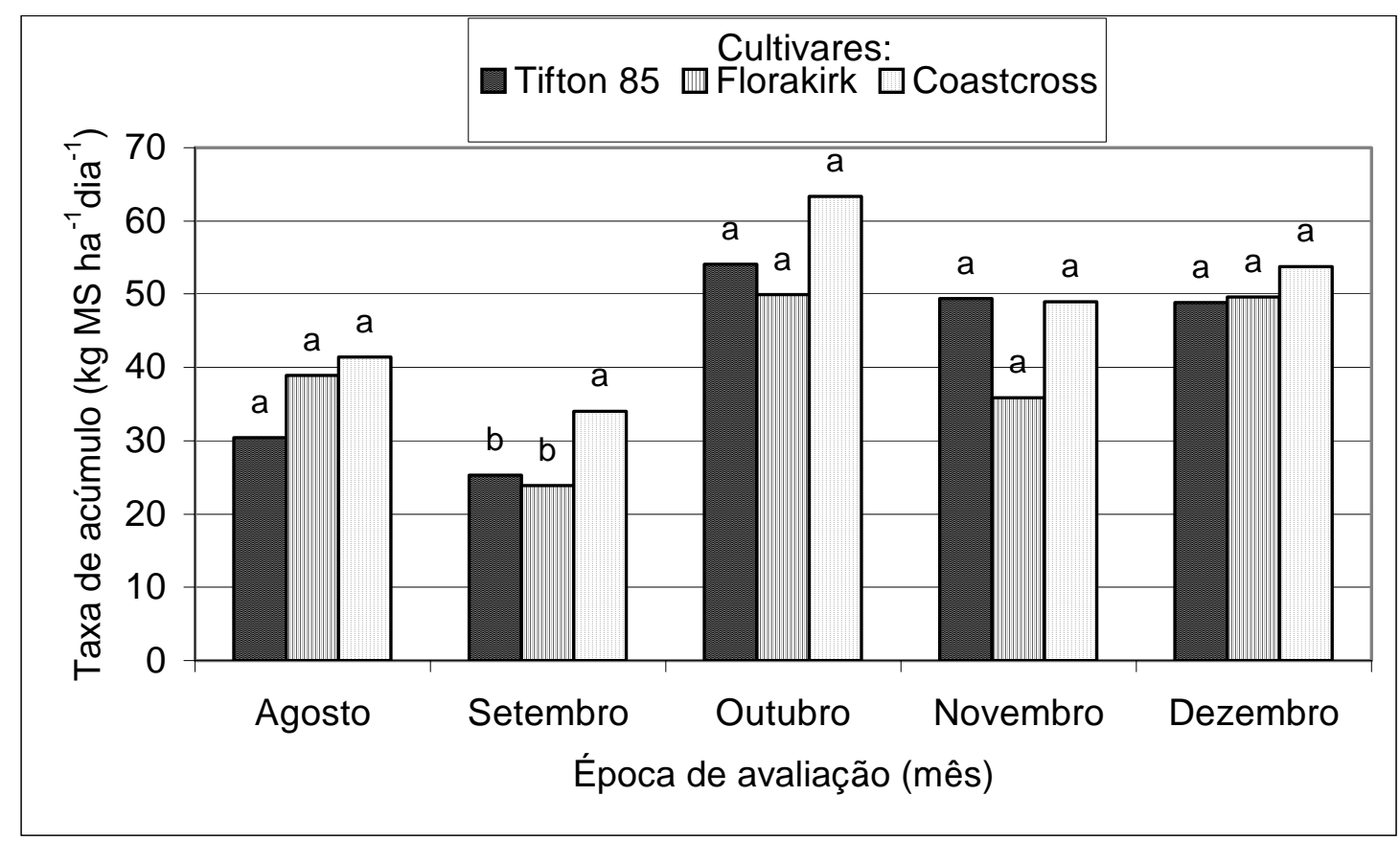

Figura 7 - Taxa de acúmulo de forragem em cultivares de Cynodon spp. sob regime de lotação contínua e em diferentes épocas de avaliação. 
Tabela 8 - Taxas de acúmulo de matéria seca $\left(\mathrm{kg} \mathrm{MS} \mathrm{ha}^{-1} \mathrm{dia}^{-1}\right)$ de agosto a dezembro de 1998 para as alturas de pastejo em estudo.

\begin{tabular}{cccccc}
\hline Mês & $\mathbf{5} \mathbf{~ c m}$ & $\mathbf{1 0} \mathbf{~ c m}$ & $\mathbf{1 5} \mathbf{~ c m}$ & $\mathbf{2 0} \mathbf{~ c m}$ & EPM \\
\hline Agosto & $36,5^{\mathrm{a}}$ & $39,3^{\mathrm{a}}$ & $31,0^{\mathrm{a}}$ & $40,8^{\mathrm{a}}$ & 4,41 \\
Setembro & $27,8^{\mathrm{a}}$ & $24,9^{\mathrm{a}}$ & $28,6^{\mathrm{a}}$ & $29,6^{\mathrm{a}}$ & 2,35 \\
Outubro & $59,3^{\mathrm{a}}$ & $56,8^{\mathrm{a}}$ & $53,5^{\mathrm{a}}$ & $53,5^{\mathrm{a}}$ & 6,75 \\
Novembro & $45,3^{\mathrm{ab}}$ & $34,0^{\mathrm{b}}$ & $42,3^{\mathrm{ab}}$ & $57,6^{\mathrm{a}}$ & 5,52 \\
Dezembro & $44,4^{\mathrm{a}}$ & $48,1^{\mathrm{a}}$ & $47,1^{\mathrm{a}}$ & $63,3^{\mathrm{a}}$ & 6,96 \\
\hline Médias na mesma linha seguidas da mesma letra minúscula são iguaii (P>0,05). & \multicolumn{2}{c}{ EPM - erro padrão da média. }
\end{tabular}

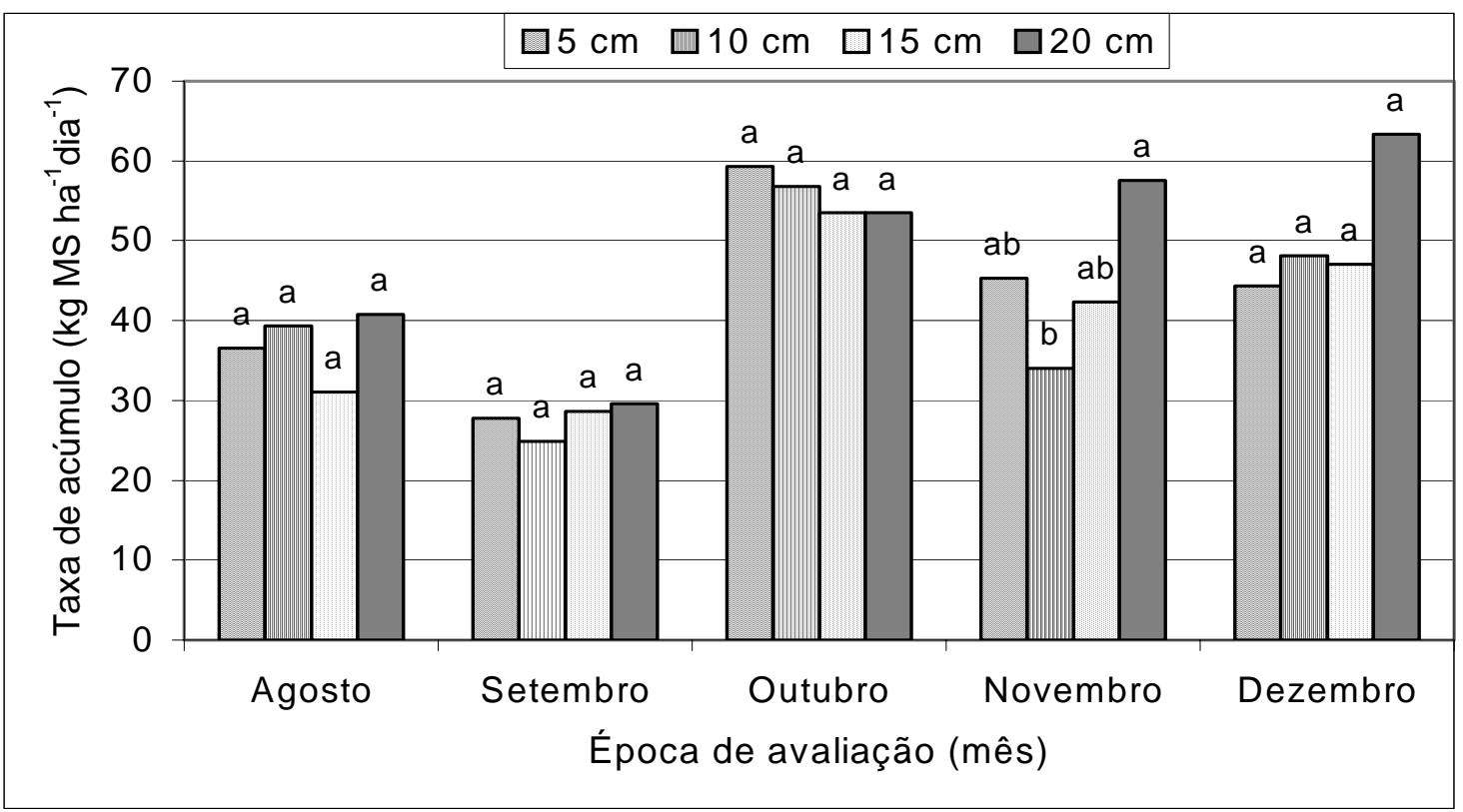

Figura 8 - Taxa de acúmulo de forragem em cultivares de Cynodon spp. sob diferentes intensidades de pastejo em regime de lotação contínua avaliados em diferentes épocas do ano.

De acordo com os resultados de Carnevalli \& da Silva (no prelo) os valores de taxa de acúmulo para Coastcross variaram entre 15,7 e 96,2 kg MS $\mathrm{ha}^{-1} \mathrm{dia}^{-1}$. No presente ensaio os valores médios de taxa de acúmulo variaram entre 23,9 e 63,3 $\mathrm{kg} \mathrm{MS} \mathrm{ha}^{-1} \mathrm{dia}^{-1}$.

Trabalho realizado por Sheehy \& Cooper (1973) com várias espécies forrageiras em condições não limitantes de umidade e nutrientes no solo demonstrou grandes diferenças varietais em taxa de crescimento, associando 
essas diferenças com variações na distribuição de luz dentro do dossel do pasto e sugerindo que a arquitetura do mesmo seria um fator importante na determinação da taxa de crescimento das culturas.

Brougham (1956) sugeriu que valores de IL ao redor de $95 \%$ resultariam em máxima atividade fotossintética e, portanto, em máxima taxa de crescimento. No presente experimento valores de IL próximos a 95\% só foram atingidos por Tifton 85, mas este valor não se refletiu em taxa de acúmulo superior aos demais cultivares, provavelmente devido às condições ambientais adversas.

Humphreys (1966b), trabalhando com Panicum maximum var trichoglume, destacou que o crescimento foi independente da intensidade de desfolha, resultados estes que corroboram aqueles obtidos no presente ensaio, onde não foi verificado o efeito da intensidade de pastejo sobre a taxa de acúmulo de matéria seca.

Clapp Jr. et al. (1965) objetivando determinar a influência da severidade da desfolha no crescimento de capim bermuda cv. Coastal relataram que a maioria dos resultados obtidos indicou produções elevadas para o regime de desfolha mais frequente e mais próximos à superfície do solo. Os autores comentaram que o esperado seria produções mais elevadas para sistemas de desfolha menos frequentes e intensos, argumentando que esses resultados teriam sido devidos à maior eficiência foliar (folhas desenvolvidas em ambiente com maior disponibilidade de luz) e a um corte de uniformização prévio que, provavelmente, influenciou as reservas das raízes e o desenvolvimento dos perfilhos.

Hodgson (1990) caracteriza o processo de acúmulo de forragem como sendo o resultado líquido do balanço entre o crescimento (produção de novos tecidos - folhas e hastes) e senescência /morte. Pastos submetidos a regimes de desfolha intensos apresentam baixas taxas de acúmulo mas, em contrapartida, baixa senescência. Por outro lado, pastos submetidos a regimes de desfolha lenientes apresentam crescimento mais acelerado que é 
compensado por taxas maiores de senescência e morte de tecidos (Tainton, 1974). Deve existir, portanto, uma amplitude de possibilidades de regime de desfolha que geram um mesmo equilíbrio, produção de forragem, a partir de balanços diferentes entre crescimento e senescência (Hodgson, 1990). Os tratamentos empregados no presente ensaio podem fazer parte dessa amplitude de possibilidades o que resultaria em produções semelhantes de matéria seca.

Segundo Clavero Cepeda (1993b) outros fatores contribuem para a falta de consistência da relação entre IL, IAF e taxa de acúmulo de matéria seca, uma vez que plantas interagem dinamicamente com outros componentes do ambiente. A partição de matéria seca é influenciada pela época e duração do estádio reprodutivo. O desenvolvimento da inflorescência nos perfilhos leva ao cessamento da emissão de novas folhas e também pode inibir o desenvolvimento de perfilhos de gemas axilares, levando a uma subsequente redução de produção (Cooper, 1983).

As taxas de acúmulo de matéria seca variaram entre 24,9 e 63,3 kg MS $\mathrm{ha}^{-1} \mathrm{dia}^{-1}$. Clavero Cepeda (1993a), trabalhando com Cenchrus ciliaris, verificou taxas de crescimento durante a primavera-verão de 16 a $160 \mathrm{~kg} \mathrm{MS} \mathrm{ha}^{-1} \mathrm{dia}^{-1}$, com a ocorrência de altas taxas durante a primavera, as quais foram relacionadas com os diferentes componentes do ambiente, principalmente os altos níveis de umidade apresentados durante aquela estação.

\subsection{Características Morfológicas}

\subsubsection{Material vivo}

Os resultados da porcentagem de material vivo estão relacionados nas Tabelas 9 e10 e Figuras 9 e 10. Houve efeito de mês ( $P=0,0001)$, cultivar $(P=0,0001)$ e mês $x$ cultivar $(P=0,019)$ os quais podem ser observados na 
Tabela 9 e Figura 9. Foi detectado efeito de mês $x$ altura $(P=0,011)$ que pode ser observado na Tabela 10 e Figura 10.

Tabela 9 - Porcentagem de material vivo no pasto de julho a dezembro de 1998 para os cultivares de Cynodon spp..

\begin{tabular}{ccccc}
\hline Mês & Tifton 85 & Florakirk & Coastcross & EPM $^{*}$ \\
\hline Julho & $58,3^{\mathrm{a}}$ & 51,5 & $57,4^{\mathrm{a}}$ & 1,58 \\
Agosto & $64,4^{\mathrm{a}}$ & $57,3^{\mathrm{b}}$ & $60,0^{\mathrm{ab}}$ & 1,77 \\
Setembro & $60,9^{\mathrm{a}}$ & $47,3^{\mathrm{b}}$ & $42,6^{\mathrm{b}}$ & 2,10 \\
Outubro & $64,1^{\mathrm{a}}$ & $61,1^{\mathrm{a}}$ & $62,9^{\mathrm{a}}$ & 1,91 \\
Novembro & $62,0^{\mathrm{ab}}$ & $59,0^{\mathrm{b}}$ & $66,9^{\mathrm{a}}$ & 2,00 \\
Dezembro & $60,0^{\mathrm{a}}$ & $54,3^{\mathrm{a}}$ & $58,3^{\mathrm{a}}$ & 2,28 \\
\hline
\end{tabular}

Tabela 10 - Porcentagem de material vivo no pasto de julho a dezembro de 1998 para as intensidades de pastejo.

\begin{tabular}{cccccc}
\hline Mês & $\mathbf{5 ~ c m}$ & $\mathbf{1 0} \mathbf{~ c m}$ & $\mathbf{1 5} \mathbf{~ c m}$ & $\mathbf{2 0} \mathbf{~ c m}$ & EPM \\
\hline Julho & $49,6^{\mathrm{b}}$ & $60,0^{\mathrm{a}}$ & $56,9^{\mathrm{a}}$ & $56,4^{\mathrm{ab}}$ & 1,83 \\
Agosto & $57,7^{\mathrm{a}}$ & $62,9^{\mathrm{a}}$ & $57,8^{\mathrm{a}}$ & $63,2^{\mathrm{a}}$ & 2,05 \\
Setembro & $48,4^{\mathrm{a}}$ & $48,4^{\mathrm{a}}$ & $48,1^{\mathrm{a}}$ & $56,1^{\mathrm{a}}$ & 2,42 \\
Outubro & $65,6^{\mathrm{a}}$ & $64,2^{\mathrm{a}}$ & $59,6^{\mathrm{a}}$ & $61,3^{\mathrm{a}}$ & 2,20 \\
Novembro & $66,5^{\mathrm{a}}$ & $63,9^{\mathrm{a}}$ & $61,4^{\mathrm{a}}$ & $58,5^{\mathrm{a}}$ & 2,31 \\
Dezembro* & $62,0^{\mathrm{a}}$ & $57,4^{\mathrm{a}}$ & $57,1^{\mathrm{a}}$ & $54,5^{\mathrm{a}}$ & 2,64 \\
\hline Médias na mesma linha seguidas da mesma letra minúscula são iguais $(\mathrm{P}>0,05)$. & EPM - erro padrão da média.
\end{tabular}




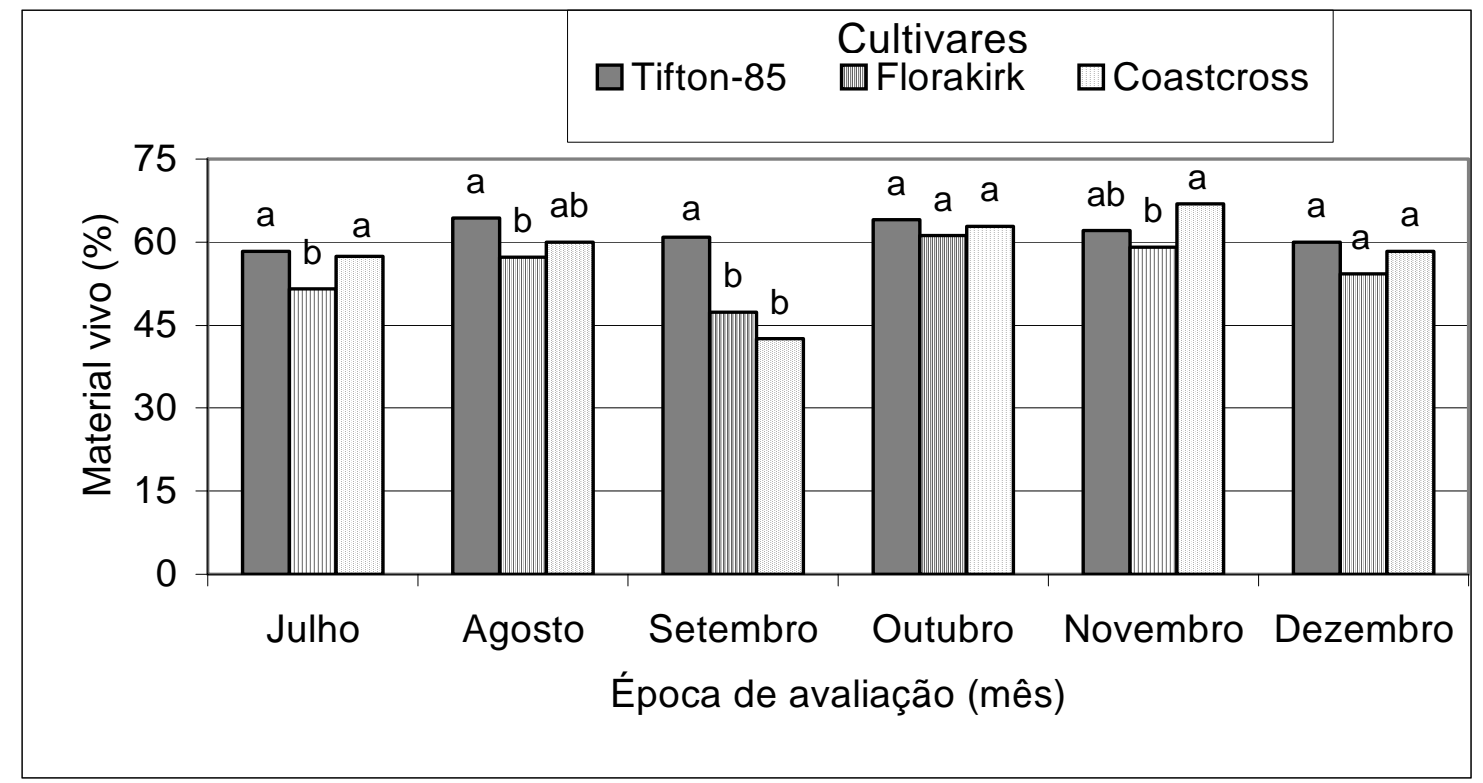

Figura 9 - Porcentagem de material vivo em cultivares de Cynodon spp. sob regime de lotação contínua e em diferentes épocas de avaliação.

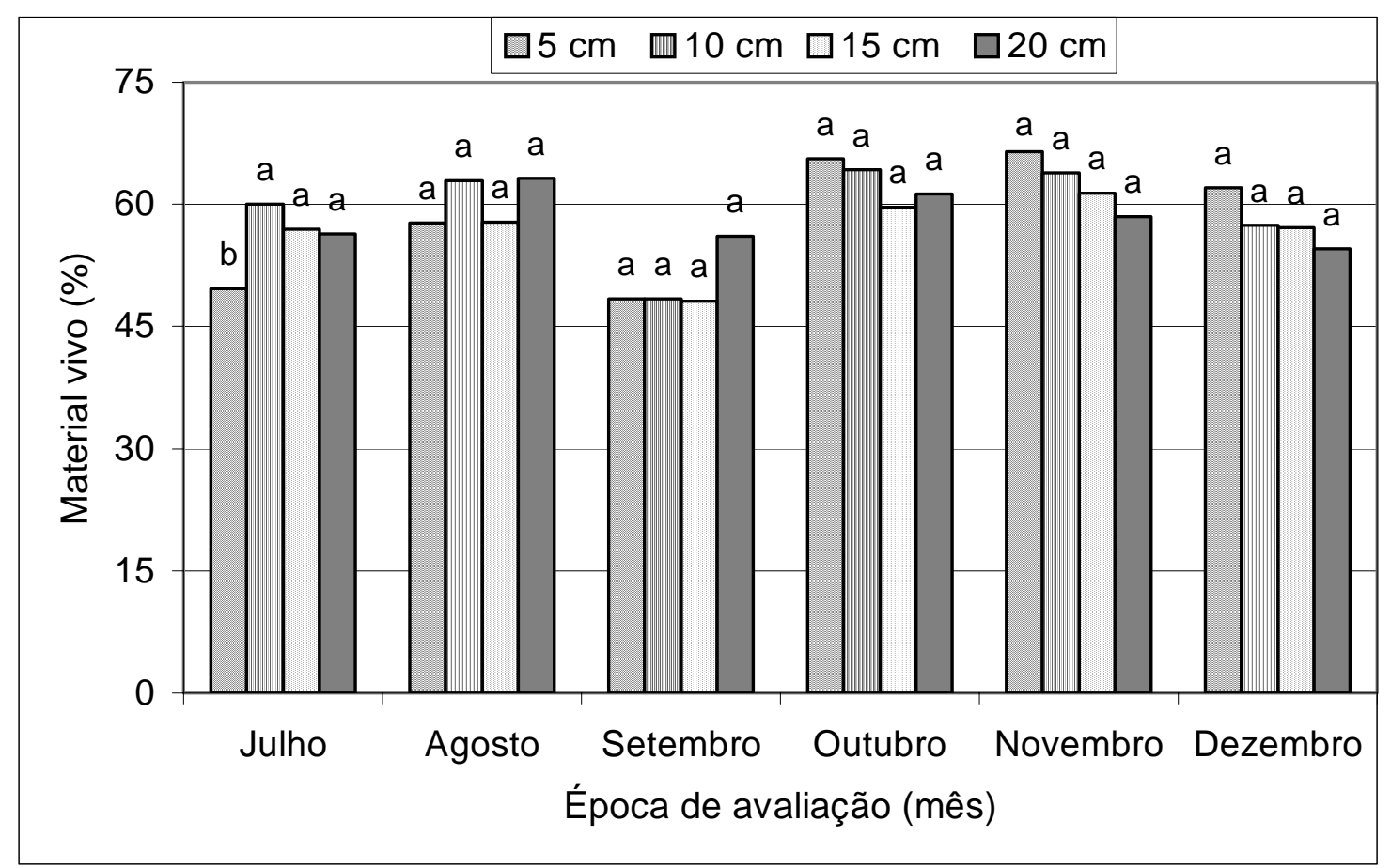

Figura 10 - Porcentagem de material vivo em cultivares de Cynodon spp. sob diferentes intensidades de pastejo em regime de lotação contínua avaliados em diferentes épocas do ano. 
Ocorreu um aumento nas proporções de material vivo à medida que se avançou na estação de crescimento (outubro, novembro e dezembro quando comparados a agosto e setembro) (Figuras 9 e 10). Este aumento deve estar relacionado com as mudanças ambientais ocorridas (Tabela 2) e à provável decomposição dos restos de forragem acumulados na superfície do solo decorrentes dos cortes de igualação realizados em janeiro e março de 1998.

A partir de outubro, quando as temperaturas começaram a se elevar e os índices pluviométricos aumentaram, as maiores intensidades de pastejo proporcionaram pastos com maior percentual de material vivo (Tabela $10 \mathrm{e}$ Figura 10). Pastos mantidos sob regime de desfolha mais intensos sabidamente têm maior proporção de material vivo (Korte \& Harris, 1987).

Clavero Cepeda (1993a) também constatou diferenças para as medidas de material vivo em Cenchrus ciliaris para cada estação do ano avaliada e entre os anos estudados. Essas variações nas proporções de material vivo e morto no pasto são o resultado do equilíbrio dos processos dinâmicos e concomitantes de crescimento e morte/senescência de tecidos (Hodgson, 1990), os quais são afetados de forma diferenciada por práticas agronômicas e de manejo (Korte \& Sheath, 1979).

\subsubsection{Folha}

Os valores de porcentagem de folha no pasto são apresentados nas Tabelas 11 e 12 e Figuras 11 e 12 . Houve efeito de mês ( $P=0,0001)$, cultivar $(P=0,0001)$ e mês $x$ cultivar $(P=0,0001)$ os quais podem ser observados na Tabela 11 e Figura 11. O efeito da interação mês $x$ altura $(P=0,0029)$ é ilustrado na Tabela 12 e Figura 12.

Não foi observado diferença referente a altura de pastejo $(P>0,05)$ sobre a porcentagem de folha no pasto apesar de Humphreys (1991) relatar que a altura de corte pode resultar em variações nas proporções de folha, caule e inflorescência. 
Tabela 11 - Porcentagem de folha no pasto de julho a dezembro de 1998 para os cultivares de Cynodon spp..

\begin{tabular}{ccccc}
\hline Mês & Tifton 85 & Florakirk & Coastcross & EPM $^{*}$ \\
\hline Julho & $24,2^{\mathrm{a}}$ & $16,9^{\mathrm{b}}$ & $17,4^{\mathrm{b}}$ & 1,01 \\
Agosto & $26,5^{\mathrm{a}}$ & $19,3^{\mathrm{b}}$ & $17,5^{\mathrm{b}}$ & 1,51 \\
Setembro & $18,4^{\mathrm{a}}$ & $10,4^{\mathrm{b}}$ & $10,8^{\mathrm{b}}$ & 0,98 \\
Outubro & $22,6^{\mathrm{a}}$ & $19,5^{\mathrm{a}}$ & $23,3^{\mathrm{a}}$ & 1,28 \\
Novembro & $15,3^{\mathrm{a}}$ & $13,9^{\mathrm{a}}$ & $17,9^{\mathrm{a}}$ & 1,13 \\
Dezembro & $12,5^{\mathrm{a}}$ & $12,1^{\mathrm{a}}$ & $17,1^{\mathrm{a}}$ & 0,79 \\
\hline Médias na mesma linha seguidas da mesma letra minúscula são iguais (P>0,05). & EPM - erro padrão da média.
\end{tabular}

Tabela 12 - Porcentagem de folha no pasto de julho a dezembro de 1998 para as intensidades de pastejo.

\begin{tabular}{cccccc}
\hline Mês & $\mathbf{5 ~ c m}$ & $\mathbf{1 0} \mathbf{~ c m}$ & $\mathbf{1 5} \mathbf{~ c m}$ & $\mathbf{2 0} \mathbf{~ c m}$ & EPM \\
\hline Julho & $15,8^{\mathrm{b}}$ & $21,5^{\mathrm{a}}$ & $20,6^{\mathrm{ab}}$ & $20,1^{\mathrm{ab}}$ & 1,27 \\
Agosto & $19,5^{\mathrm{a}}$ & $22,7^{\mathrm{a}}$ & $19,5^{\mathrm{a}}$ & $21,4^{\mathrm{a}}$ & 1,75 \\
Setembro & $11,8^{\mathrm{a}}$ & $10,9^{\mathrm{a}}$ & $12,1^{\mathrm{a}}$ & $15,3^{\mathrm{a}}$ & 1,14 \\
Outubro & $21,7^{\mathrm{a}}$ & $22,9^{\mathrm{a}}$ & $20,9^{\mathrm{a}}$ & $21,7^{\mathrm{a}}$ & 1,48 \\
Novembro & $19,4^{\mathrm{a}}$ & $16,4^{\mathrm{ab}}$ & $13,8^{\mathrm{b}}$ & $13,4^{\mathrm{b}}$ & 1,31 \\
Dezembro $^{*}$ & $15,0^{\mathrm{a}}$ & $14,6^{\mathrm{a}}$ & $13,7^{\mathrm{a}}$ & $12,3^{\mathrm{a}}$ & 0,91 \\
\hline \multicolumn{2}{l}{ Médias na mesma linha seguidas da mesma letra minúscula são iguais $(\mathrm{P}>0,05)}$. & \multicolumn{2}{c}{ EPM - erro padrão da média. }
\end{tabular}

Ocorreu uma diminuição nos valores de porcentagem de folha no pasto nos meses de setembro, novembro e dezembro quando comparados a julho, agosto e outubro (Figuras 11 e 12). Provavelmente a redução da porcentagem de folhas no pasto verificada no mês de setembro foi devida aos cultivares Coastcross e Florakirk apresentarem-se em pleno desenvolvimento reprodutivo, o qual limitaria a emissão de novas folhas nos perfilhos. Já nos meses de novembro e dezembro, os baixos valores observados podem ter sido relacionados com as mudanças ambientais ocorridas (Tabela 2), conforme já discutido anteriormente. 


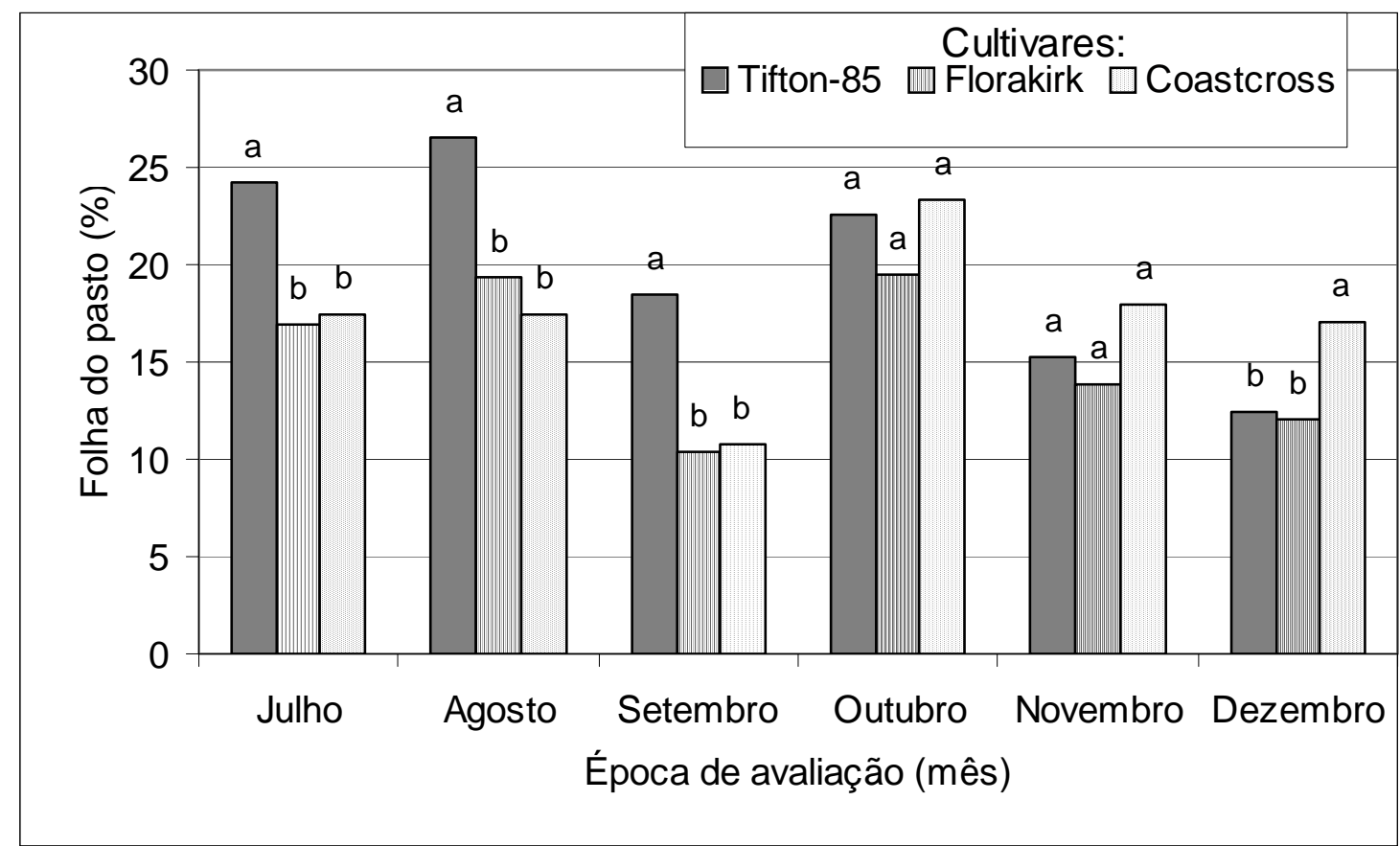

Figura 11 - Porcentagem de folha em cultivares de Cynodon spp. sob regime de lotação contínua e em diferentes épocas de avaliação.

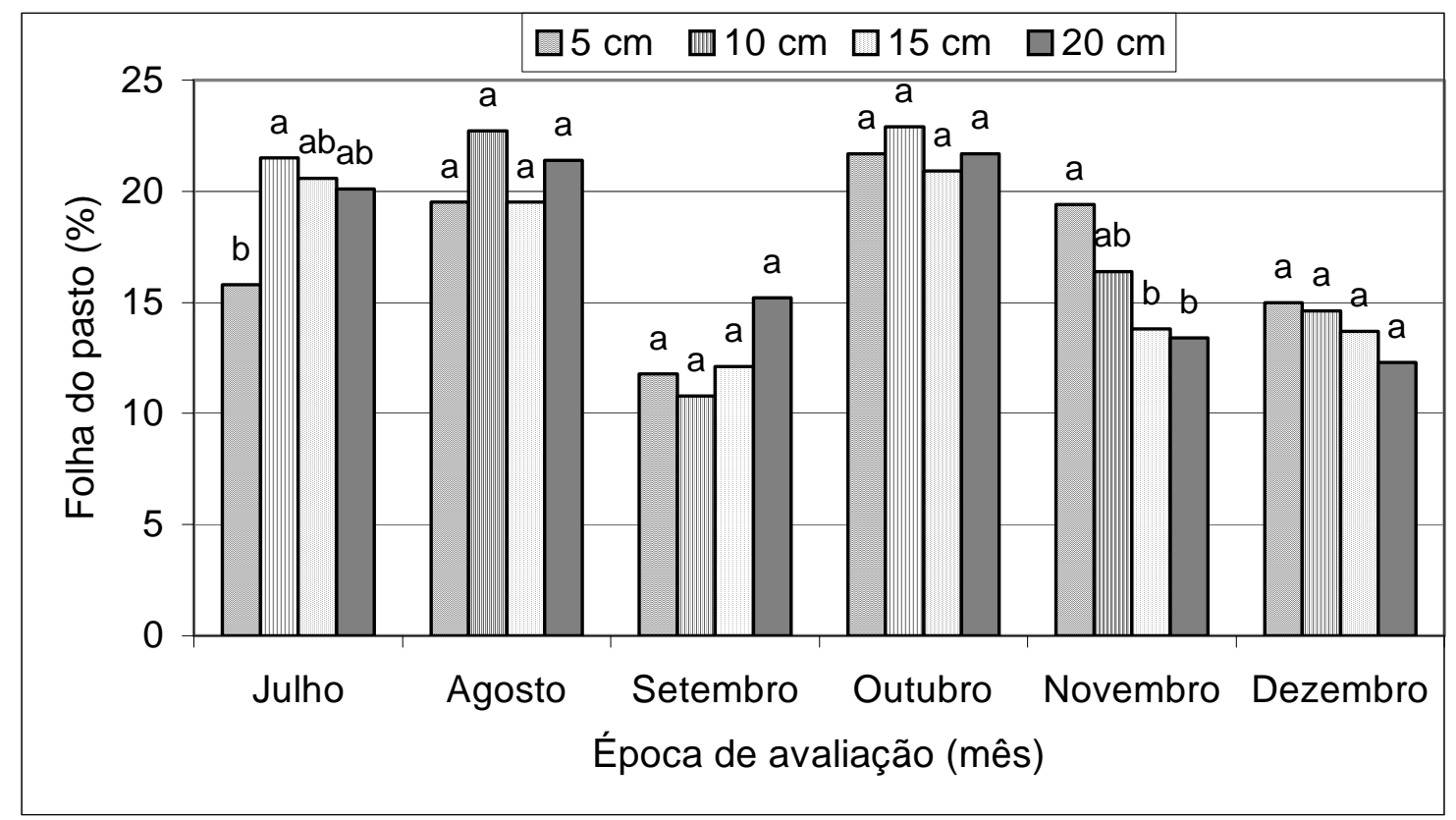

Figura 12 - Porcentagem de folha em cultivares de Cynodon spp. sob diferentes intensidades de pastejo em regime de lotação contínua avaliados em diferentes épocas do ano. 
A partir do mês de outubro desfolhas mais intensas apresentaram a tendência de apresentar maiores proporções de folha no pasto, seguindo o mesmo comportamento já relatado no material vivo.

De acordo com os resultados de Carnevalli \& da Silva (1999), os valores porcentuais de folha para Coastcross variaram entre 13,7 e $36,9 \%$. Esses autores citaram que a quantidade de folhas apresentou seu valor mais elevado quando os fatores de crescimento não eram limitantes (de agosto a março) reduzindo a partir daí quando a planta perdeu sua capacidade de reposição rápida de folhas, por causa da queda de temperatura e umidade, tendo a menor proporção sido registrada em julho. No presente ensaio os valores médios de folhas apresentaram uma variação na faixa de 10,4 a 27,1\%. Esta menor variação possivelmente deve-se à curta duração do período de avaliação (6 meses) e/ou aos diferentes métodos de pastejo empregados (lotação contínua vs pastejo rotacionado).

Entretanto, Clapp Jr. et al. (1965) em trabalho realizado durante três anos, mencionam que as lâminas verdes variaram de 13 a 18,8\% nas estratégias de desfolhas avaliadas, resultados esses que corroboram os observados no presente ensaio.

\subsubsection{Haste}

Os resultados de porcentagem de haste no pasto são mostrados nas Tabelas 13 e 14 e Figuras 13 e 14 . Houve efeito de mês $(P=0,0001)$, cultivar $(P=0,0001)$ e mês $x$ cultivar $(P=0,0001)$ os quais são apresentados na Tabela 13 e Figura 13. Foi observado efeito de mês $x$ altura $(P=0,0029)$ o qual pode ser verificado na Tabela 14 e Figura 14.

Ocorreu um aumento dos valores de haste no pasto à medida que avançou-se na estação de crescimento (meses de novembro e dezembro quando comparados aos demais meses) (Figuras 13 e 14). Este comportamento é o inverso daquele verificado para a porcentagem de folhas, 0 
que já era esperado uma vez que ambos são componentes complementeres do "pool" de material vivo do pasto.

Tabela 13 - Porcentagem de haste no pasto de julho a dezembro de 1998 para os cultivares de Cynodon spp..

\begin{tabular}{ccccc}
\hline Mês & Tifton 85 & Florakirk & Coastcross & EPM $^{*}$ \\
\hline Julho & $34,1^{\mathrm{b}}$ & $34,6^{\mathrm{b}}$ & $40,0^{\mathrm{a}}$ & 1,41 \\
Agosto & $37,8^{\mathrm{a}}$ & $36,9^{\mathrm{a}}$ & $42,5^{\mathrm{a}}$ & 1,73 \\
Setembro & $44,5^{\mathrm{a}}$ & $36,9^{\mathrm{b}}$ & $31,8^{\mathrm{b}}$ & 2,04 \\
Outubro & $41,5^{\mathrm{a}}$ & $41,6^{\mathrm{a}}$ & $39,6^{\mathrm{a}}$ & 1,28 \\
Novembro & $46,7^{\mathrm{a}}$ & $45,0^{\mathrm{a}}$ & $49,0^{\mathrm{a}}$ & 1,74 \\
Dezembro & $47,5^{\mathrm{a}}$ & $42,2^{\mathrm{a}}$ & $41,2^{\mathrm{a}}$ & 2,46 \\
\hline Médias na mesma linha seguidas da mesma letra minúscula são iguais (P>0,05). & \multicolumn{2}{c}{ EPM - erro padrão da média $^{2}$}
\end{tabular}

Tabela 14 - Porcentagem de haste no pasto de julho a dezembro de 1998 para as intensidades de pastejo.

\begin{tabular}{cccccc}
\hline Mês & $\mathbf{5 ~ c m}$ & $\mathbf{1 0} \mathbf{~ c m}$ & $\mathbf{1 5} \mathbf{~ c m}$ & $\mathbf{2 0} \mathbf{~ c m}$ & EPM \\
\hline Julho & $33,7^{\mathrm{a}}$ & $38,5^{\mathrm{a}}$ & $36,4^{\mathrm{a}}$ & $36,3^{\mathrm{a}}$ & 1,63 \\
Agosto & $38,1^{\mathrm{a}}$ & $39,2^{\mathrm{a}}$ & $38,3^{\mathrm{a}}$ & $40,7^{\mathrm{a}}$ & 2,00 \\
Setembro & $36,6^{\mathrm{a}}$ & $37,8^{\mathrm{a}}$ & $36,0^{\mathrm{a}}$ & $40,7^{\mathrm{a}}$ & 2,36 \\
Outubro & $43,9^{\mathrm{a}}$ & $41,3^{\mathrm{a}}$ & $38,7^{\mathrm{a}}$ & $39,7^{\mathrm{a}}$ & 2,26 \\
Novembro & $47,1^{\mathrm{a}}$ & $47,5^{\mathrm{a}}$ & $47,7^{\mathrm{a}}$ & $45,2^{\mathrm{a}}$ & 2,01 \\
Dezembro & $47,8^{\mathrm{a}}$ & $42,3^{\mathrm{a}}$ & $43,4^{\mathrm{a}}$ & $40,4^{\mathrm{a}}$ & 2,84 \\
\hline \multicolumn{1}{l}{ Médias na mesma linha seguidas da mesma letra minúscula são iguais (P>0,05). } & \multicolumn{2}{c}{ EPM - erro padrão da média. }
\end{tabular}

De acordo com os resultados de Carnevalli \& da Silva (1999) os valores percentuais de haste para Coastcross variaram entre 22,1 e 56,2\%. Esses autores citaram que a quantidade de hastes manteve-se constante ao longo do período de novembro a março, diminuindo a partir da entrada do outono. No presente ensaio os valores médios de haste apresentaram uma variação na faixa de 31,8 a 49,0\%. Esta menor variação possivelmente deve-se aos diferentes métodos de desfolha empregados no presente ensaio além de, adicionalmente, as intensidades de pastejo estudadas terem sido superiores àquelas empregadas pelos autores citados. 


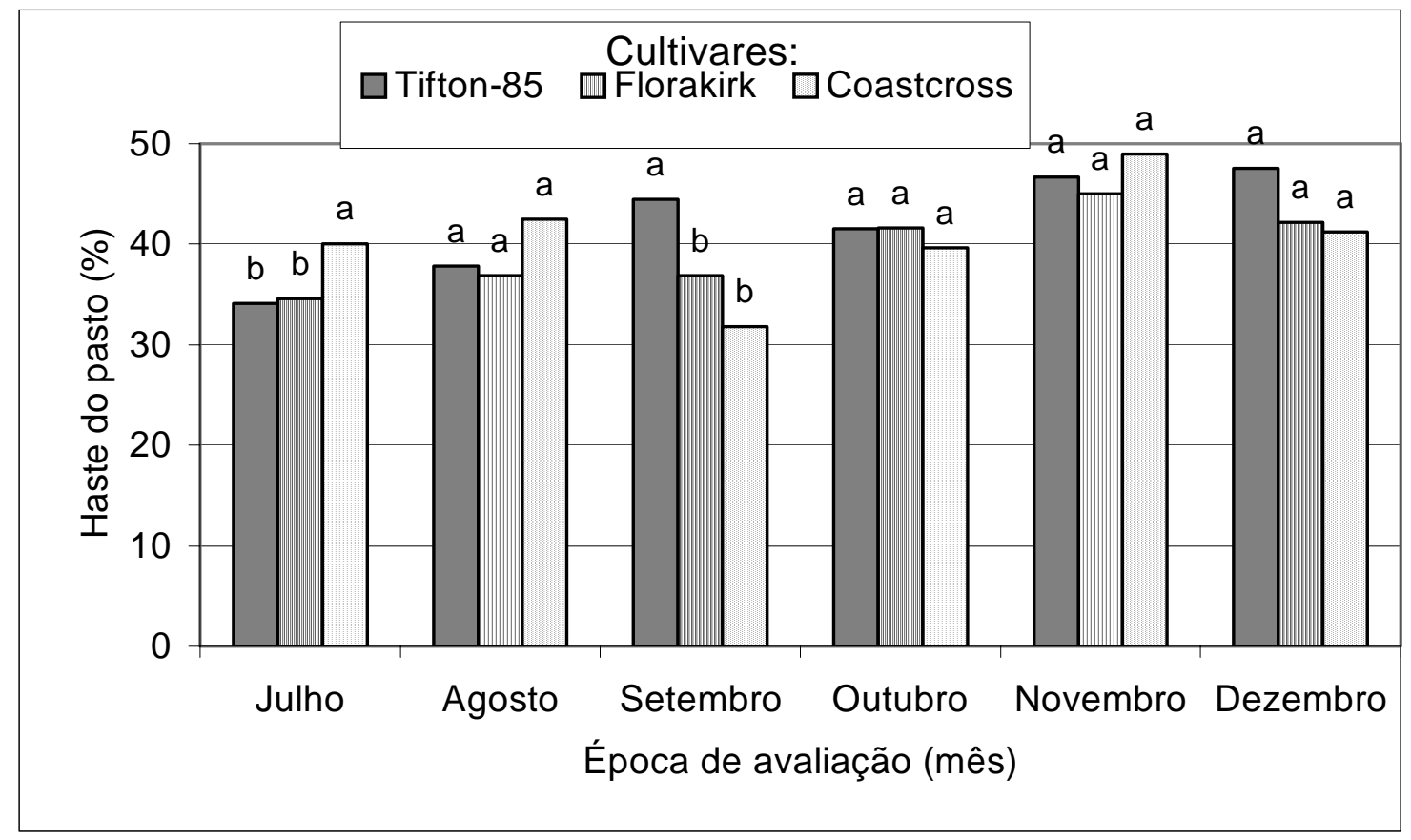

Figura 13 - Porcentagem de haste em cultivares de Cynodon spp. sob regime de lotação contínua e em diferentes épocas de avaliação.

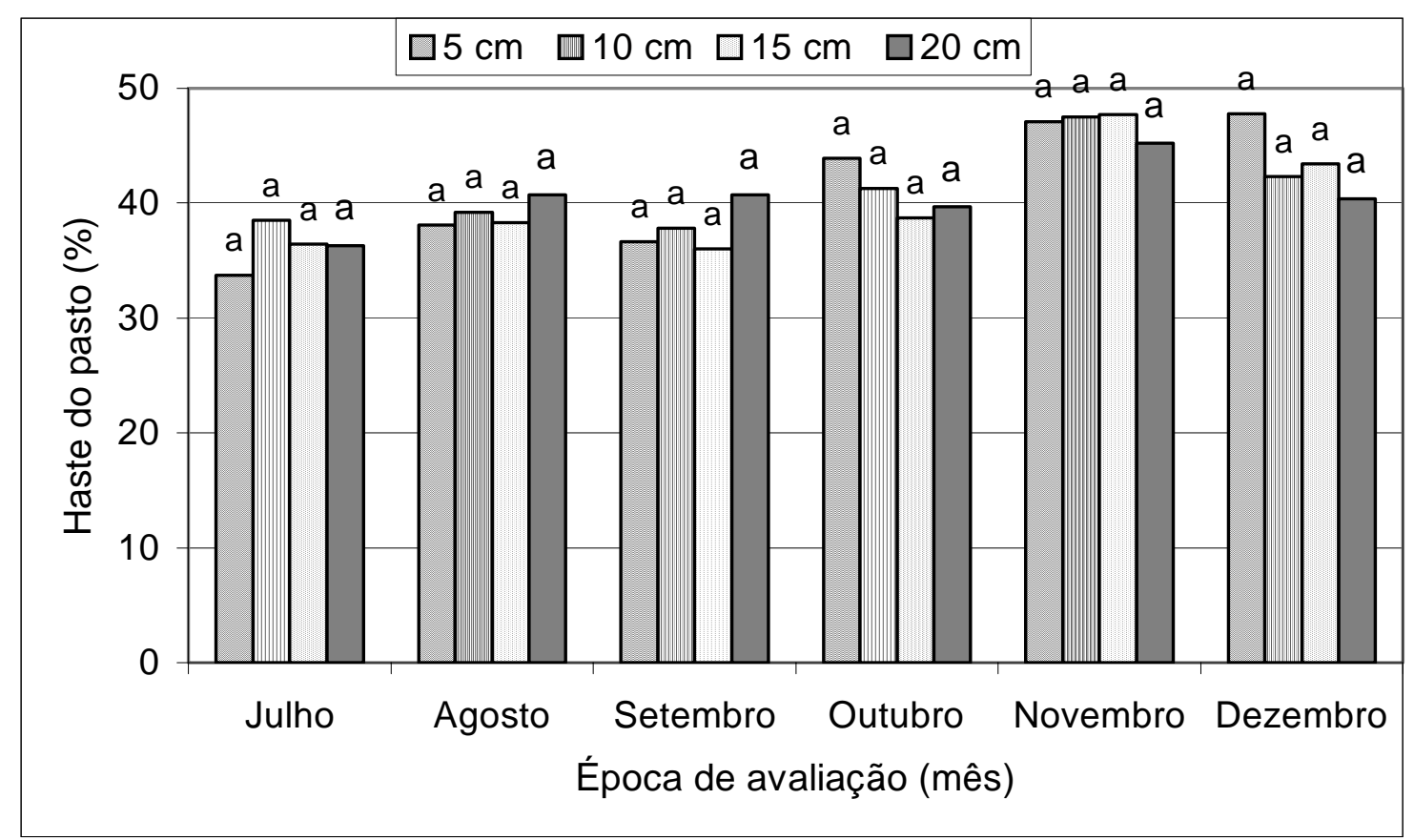

Figura 14 - Porcentagem de haste em cultivares de Cynodon spp. sob diferentes intensidades de pastejo em regime de lotação contínua avaliados em diferentes épocas do ano. 


\subsubsection{Material morto}

Os dados referentes a porcentagem de material morto são indicados nas Tabelas 15 e 16 e Figuras 15 e 16. Foram detectados efeitos de mês $(P=0,0001)$, cultivar $(P=0,0057)$ e mês $x$ cultivar $(P=0,036)$ os quais podem ser observados na Tabela 15 e Figura 15. Houve efeito de mês $x$ altura $(P=0,065) 0$ qual pode ser observado na Tabela 16 e Figura 16.

Tabela 15 - Porcentagem de material morto no pasto de julho a dezembro de 1998 para os cultivares de Cynodon spp..

\begin{tabular}{ccccc}
\hline Mês & Tifton 85 & Florakirk & Coastcross & EPM $^{\mathbf{*}}$ \\
\hline Julho & $41,7^{\mathrm{a}}$ & $42,0^{\mathrm{a}}$ & $46,0^{\mathrm{a}}$ & 1,97 \\
Agosto & $35,6^{\mathrm{b}}$ & $43,2^{\mathrm{a}}$ & $40,0^{\mathrm{ab}}$ & 1,90 \\
Setembro & $39,1^{\mathrm{b}}$ & $52,6^{\mathrm{a}}$ & $57,4^{\mathrm{a}}$ & 2,10 \\
Outubro & $35,9^{\mathrm{a}}$ & $37,7^{\mathrm{a}}$ & $37,1^{\mathrm{a}}$ & 2,06 \\
Novembro & $38,0^{\mathrm{a}}$ & $40,3^{\mathrm{a}}$ & $33,1^{\mathrm{a}}$ & 2,18 \\
Dezembro & $40,0^{\mathrm{a}}$ & $44,6^{\mathrm{a}}$ & $41,7^{\mathrm{a}}$ & 2,64 \\
\hline Médias na mesma linha seguidas da mesma letra minúscula são iguais (P>0,05). & \multicolumn{2}{c}{ EPM - erro padrão da média. }
\end{tabular}

Tabela 16 - Porcentagem de material morto no pasto de julho a dezembro de 1998 para as intensidades de pastejo.

\begin{tabular}{|c|c|c|c|c|c|}
\hline Mês & $5 \mathrm{~cm}$ & $10 \mathrm{~cm}$ & $15 \mathrm{~cm}$ & $20 \mathrm{~cm}$ & EPM \\
\hline Julho & $49,0^{a}$ & $39,5^{b}$ & $43,2^{a b}$ & $42,1^{\text {ab }}$ & 2,27 \\
\hline Agosto & $42,6^{a}$ & $37,2^{\mathrm{a}}$ & $43,0^{a}$ & $36,7^{\mathrm{a}}$ & 2,19 \\
\hline Setembro & $51,5^{a}$ & $51,6^{a}$ & $51,9^{a}$ & $43,8^{a}$ & 2,43 \\
\hline Outubro & $34,8^{a}$ & $35,2^{a}$ & $35,2^{a}$ & $39,2^{a}$ & 2,38 \\
\hline Novembro & $34,0^{\mathrm{a}}$ & $35,8^{a}$ & $35,8^{a}$ & $41,1^{\mathrm{a}}$ & 2,52 \\
\hline Dezembro* & $38,4^{a}$ & $42,5^{\mathrm{a}}$ & $42,9^{a}$ & $45,6^{a}$ & 3,06 \\
\hline
\end{tabular}

A porcentagem de material morto no pasto não apresentou uma variação marcante durante o período experimental, exceto no mês de setembro onde os cultivares Coastcross e Florakirk apresentaram os valores mais 
elevados (Figuras 15, 16, 17, 18 e 19). A partir do mês de outubro, tratamentos correspondentes a regimes de desfolha mais severos apresentaram menores proporções de material morto no pasto, comportamento este complementar àquele relatado para material vivo (Figura 16).

Clapp Jr. et al. (1965) observaram que plantas de Coastal bermuda submetidas a desfolhas mais severas continham a menor porcentagem de material morto. Em tratamentos menos severamente desfolhados a Coastal bermuda apresentou autosombreamento e a porcentagem de material morto observado foi maior.

De uma forma geral os pastos apresentaram cerca de $60 \%$ de material vivo e $40 \%$ de material morto, sendo que para intensidades mais lenientes de pastejo estes valores foram próximos de $50 \%$ e $50 \%$. Os valores obtidos para material morto no pasto podem ser considerados elevados e poderiam ser um indício de baixa utilização da forragem produzida. No entanto, uma análise mais cuidadosa dos fatos permite inferir que isso pode não ser verdade, uma vez que a forragem sendo utilizada seria aquela sendo consumida acima da altura de pastejo especificada, ficando a biomassa abaixo desta com acesso bastante restrito ao animal. Neste caso os resultados estariam apontando apenas para uma mudança na estrutura dos pastos apresentados aos animais.

Provavelmente o aumento do percentual de material morto em setembro deveu-se à senescência e morte de perfilhos que encontravam-se na fase reprodutiva. Como no mês de outubro ocorreu um aumento no percentual de material vivo, resultante de condições ambientais favoráveis, especialmente precipitação pluviométrica, somada ao efeito da adubação nitrogenada (realizada em 19 de setembro e 21 de outubro), ocorreu uma diminuição do material morto. Já nos meses de novembro e dezembro estes valores tenderam a estabilizar-se. Wilson \& Mannetje (1978) analisaram os efeitos das variáveis ambientais sobre a senescência foliar de Panicum maximum e Cenchrus ciliaris mostrando que elevado estresse hídrico, seguido de períodos úmidos, acelerou a senescência. 
Carnevalli \& da Silva (no prelo) trabalhando com Cynodon dactylon var Coastcross encontraram uma grande quantidade de material morto pós-pastejo, com valores de 40 a $70 \%$ da massa disponível no pré-pastejo. Os dados de composição botânica revelaram que este resíduo era formado praticamente por hastes e material morto, indicando grande seletividade por parte dos ovinos e baixo índice de utilização da forragem produzida sob as condições de manejo do pastejo utilizadas em seu ensaio.

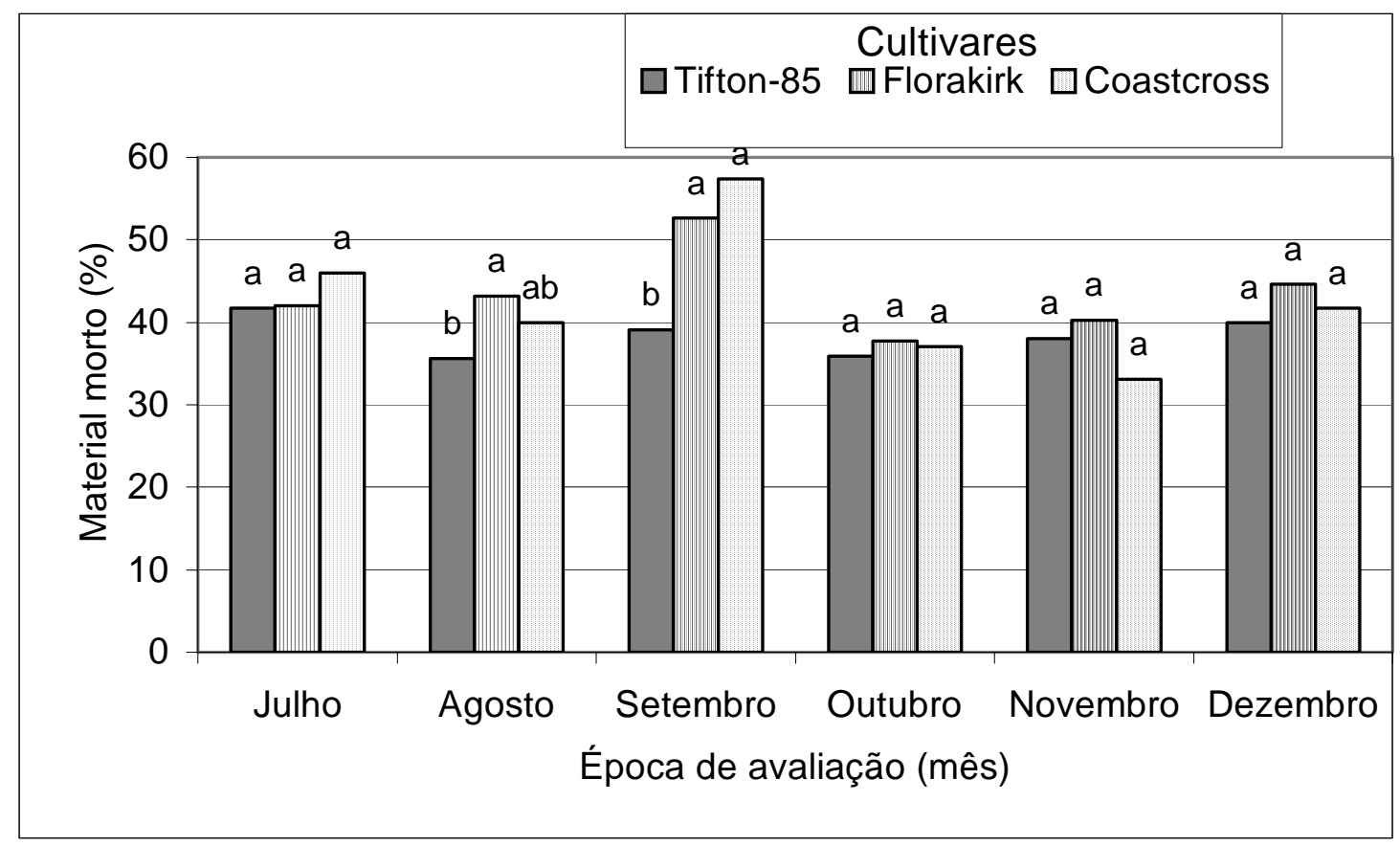

Figura 15 - Porcentagem de material morto em cultivares de Cynodon spp. sob regime de lotação contínua e em diferentes épocas de avaliação. 


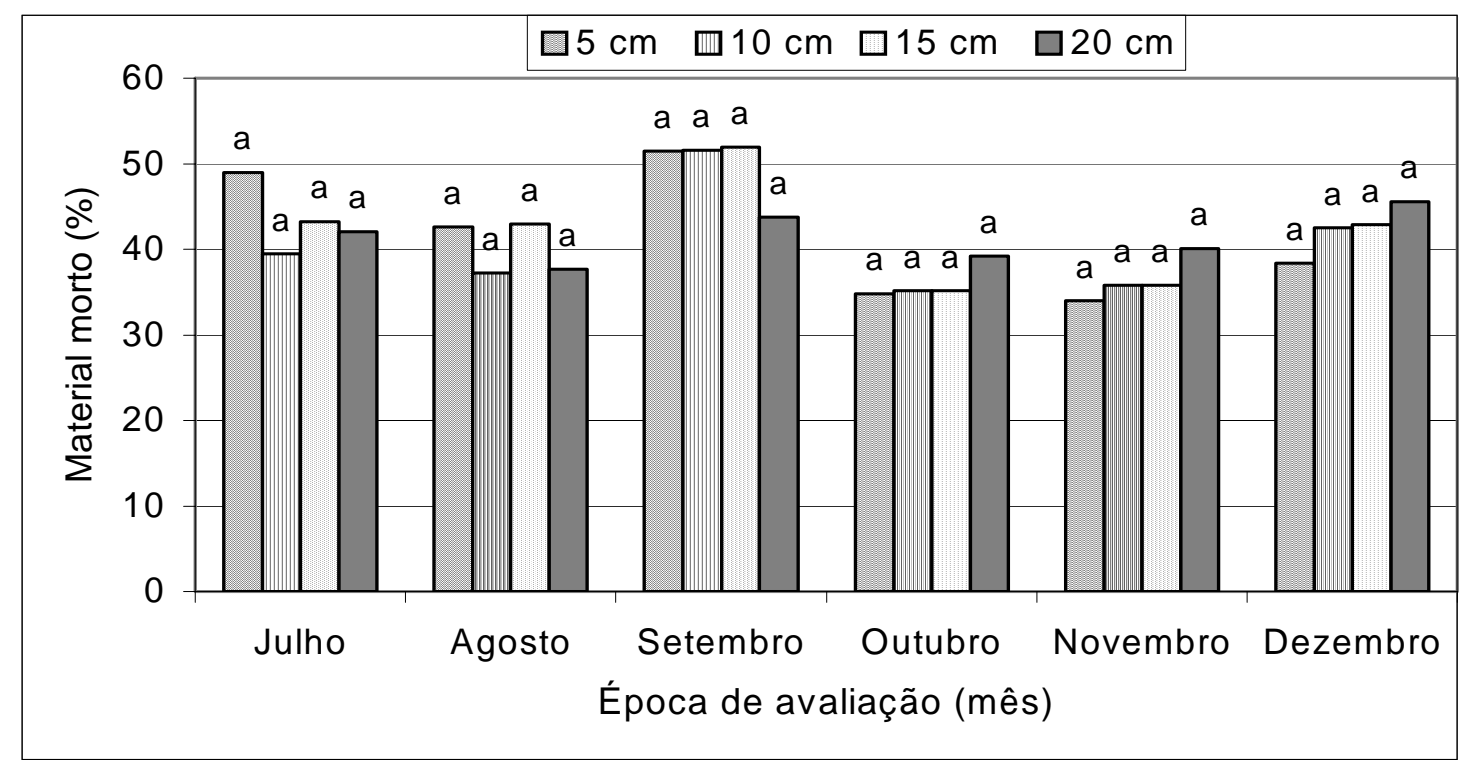

Figura 16 - Porcentagem de material morto em cultivares de Cynodon spp. sob diferentes intensidades de pastejo em regime de lotação contínua avaliados em diferentes épocas do ano.

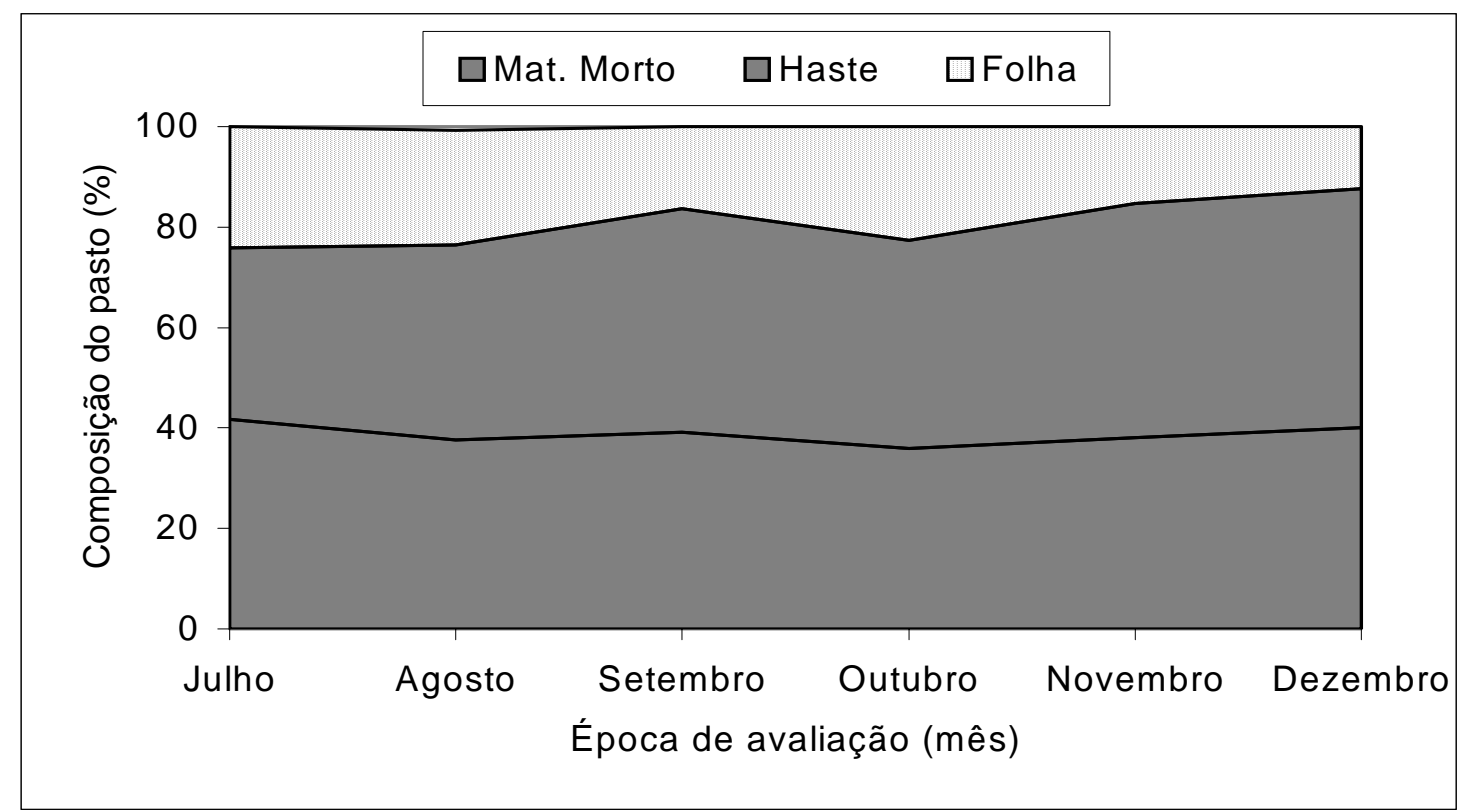

Figura 17 - Composição botânica/morfológica de pastos de Tifton 85 sob diferentes intensidades de pastejo em regime de lotação contínua avaliados em diferentes épocas do ano. 


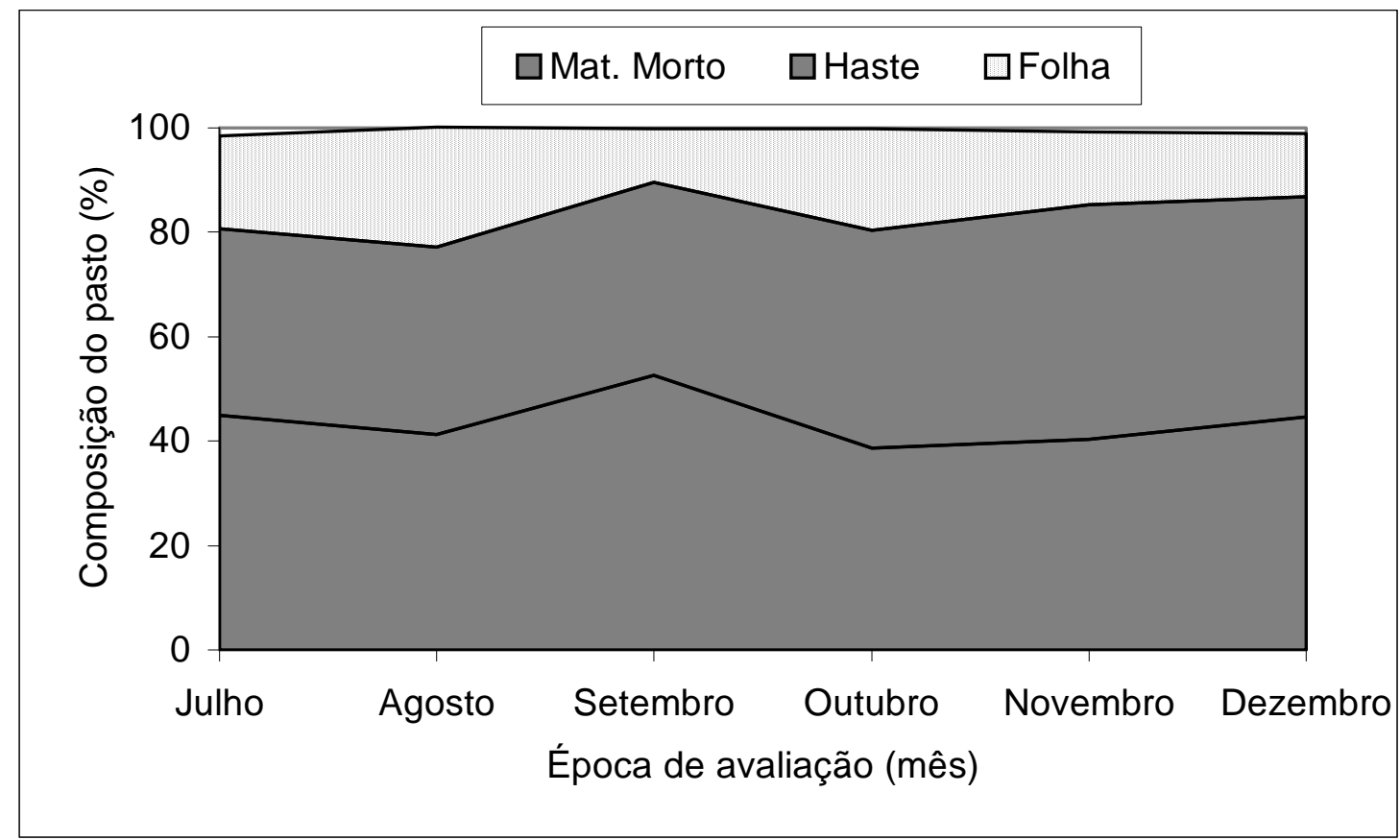

Figura 18 - Composição botânica/morfológica de pastos de Florakirk sob diferentes intensidades de pastejo em regime de lotação contínua avaliados em diferentes épocas do ano.

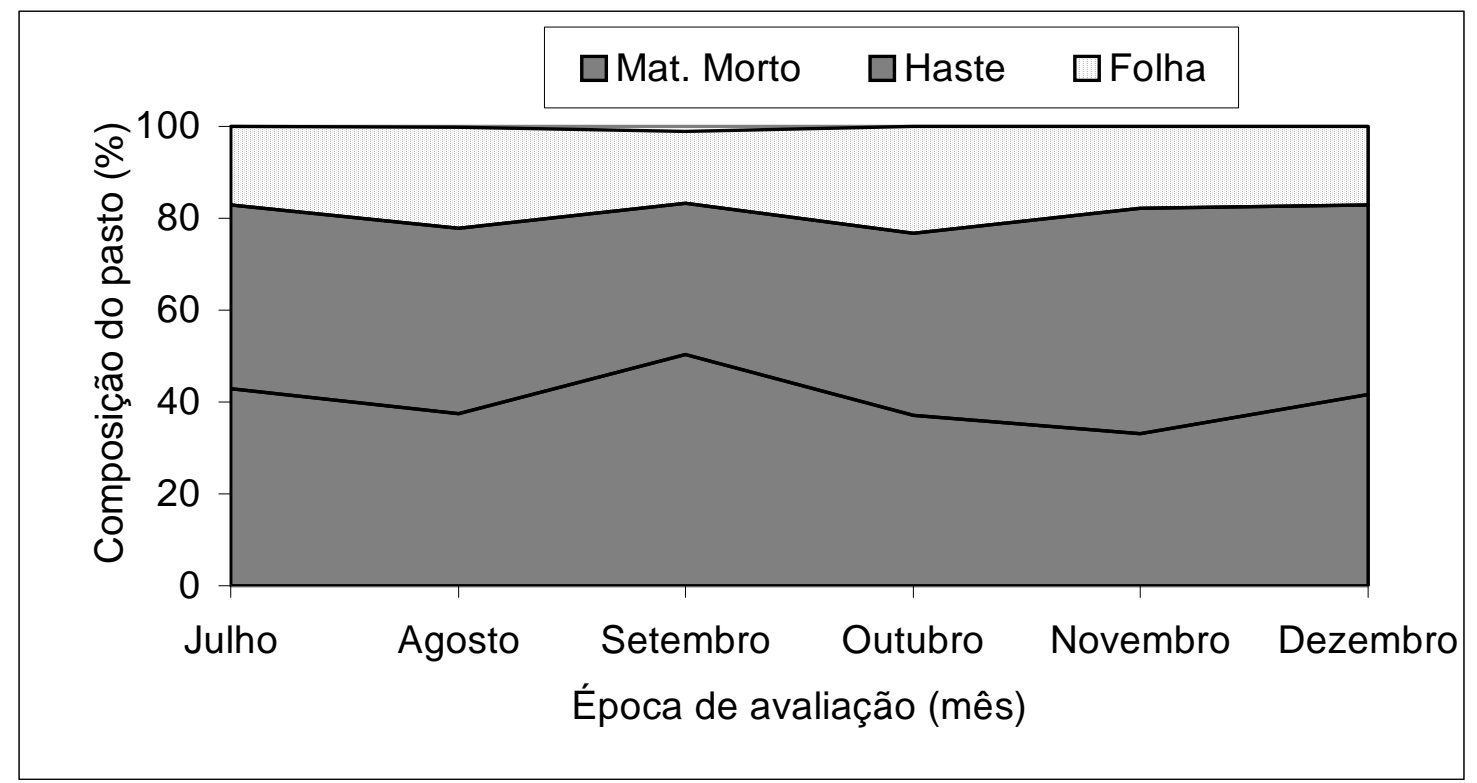

Figura 19 - Composição botânica/morfológica de pastos de Coastcross sob diferentes intensidades de pastejo em regime de lotação contínua avaliados em diferentes épocas do ano. 


\subsection{Considerações Finais}

Os resultados obtidos apontaram para um comportamento bastante diferenciado entre os tratamentos (cultivar $x$ altura). Os diferentes cultivares demonstraram um comportamento distinto em termos de florescimento, fato este que pode ter sido responsável pela maior parte das interações observados entre mês $x$ cultivar, mês $x$ altura, cultivar $x$ altura, etc.. Pode-se inferir, no entanto, que os cultivares diferiram com relação ao manejo e apresentaram diferenças de comportamento fenológico em relação aos regimes de desfolha impostos. Assim, um período maior de avaliação se faz necessário a fim de que inferências precisas possam ser feitas sobre o comportamento fenológico desses cultivares em relação aos regimes de desfolha impostos.

É obvio que sob práticas pastoris usuais, luz não é um fator limitante ao crescimento de Cynodon spp. em ambientes tropicais. Maior atenção deve ser direcionada para a melhoria das condições de fertilidade do solo e minimização dos estresses hídricos antes que se possa aplicar conceitos convencionais de IAF ótimo e uso eficiente de luz. Assim para que o manejo de pastagens possa ser feito de forma apropriada é necessário que os fatores de crescimento sejam fornecidos de forma equilibrada e dosada, e seu uso, pela planta, ajustado por práticas de desfolha que permitam uma interação positiva e harmoniosa entre todos os processos biológicos da pastagem (interceptação de luz, fotossíntese, respiração, crescimento, senescência e consumo). 


\section{CONCLUSÕES}

A partir dos resultados obtidos no presente ensaio foram elaboradas as seguintes conclusões:

Apesar dos cultivares estudados pertencerem ao mesmo gênero e apresentarem porte e hábito de crescimento semelhante, Tifton 85 mostrou a maior densidade de IAF ao longo do perfil do pasto, e essa diferença foi atribuída a variação na morfologia das plantas;

A amplitude de condições de pasto (intensidade de pastejo) estudada deve ter se situado dentro de uma faixa onde o equilíbrio entre crescimento e senescência resultou em taxas de acúmulo de forragem semelhantes;

Tifton 85 apresentou como faixa ótima de uso condições de pasto que variaram de 5 a $15 \mathrm{~cm}$;

Para Florakirk essa faixa foi até $20 \mathrm{~cm}$ e para Coastcross o limite superior deve ser maior que $20 \mathrm{~cm}$;

Diferentes cultivares devem possuir requerimentos variados de manejo de desfolha quando o objetivo é o uso eficiente da luz e demais fatores de crescimento associado a elevados índices de utilização da forragem produzida; 


\section{REFERÊNCIAS BIBLIOGRÁFICAS}

BERNARDES, M.S. Fotossíntese no dossel das plantas cultivadas. In: CASTRO , P.R.C.; FERREIRA , S.O ; YAMADA , T.(Ed.) Ecofisiologia da produção agrícola. Piracicaba: Associação Brasileira de Pesquisa de Potassa e do Fosfato, 1987, p.13-48.

BOMMER, D.F. Influence of cutting frequency and nitrogen level on the carbohydrate reserves of three grass species. In: HILL, A.G.G.(Ed.) INTERNATIONAL GRASSLAND CONGRESS, 10, Helsinki, Filand, 1966. Proceedings. Filand :Univ. Helsinki, 1966. p.156-160.

BRASIL. Ministério da Agricultura. Serviço Nacional de Pesquisa Agronômica. Comissão de Solos. Levantamento de reconhecimento dos solos do estado de São Paulo. Rio de Janeiro, 1960. 634p. (Boletim, 12).

BROUGHAM, R.M. Effects of intensity of defoliation on regrowth of pastures. Australian Journal Agriculture Research, ,v.7, n.5, p.377-387,1956.

BROUGHAM, R.M. Interception of light by the foliage of pure and mixed stands of pasture plants. Australian Journal Agriculture Research, v.9, p.39-52, 1957.

BROWN, R.H.; BLASER, R.E. Leaf area index in pasture growth. Herbage Abstracts ,v.38, n.1, p.1-9, March 1968. 
BROWN, R.H.; COOPER, R.B.; BLASER, R.E. Effects of leaf age on efficiency. Crop Science, v.6, n.2, p.206-209, 1966.

BURTON, G.W. Breeding bermudagrass for the southeastern United States. Journal of the American Society of Agronomy, v.39, p.551-569, 1947.

BURTON, G.W. Registration of 'Coastcross-1' bermudagrass. Crop Science, v.12, p.125, 1972.

BURTON, G.W.; GATES, R.N.; HILL, G.M. Registration of 'Tifton 85' bermudagrass. Crop Science, v.33, p.644-645, 1993.

CARNEVALLI, R.A.; DA SILVA, S.C. Validação de técnicas experimentais para avaliação de características agronômicas e ecológicas de pastagens de Cynodon dactylon cv. Coastcross-1. Scientia Agrícola (no prelo).

CLAPP Jr, J.G.; CHAMBLEE, B.S.; GROSS, H.D. Interrelationschips between defoliation systems, morphological characteristics and growth of 'Coastal bermudagrass'. Crop Science, v.5, p.428-471, 1965.

CLAVERO CEPEDA, T. Interrelación entre índice de área foliar, intercepción de luz y crecimiento del pasto buffel (Cenchrus ciliaris L.). Revista de Agronomía (LUZ), v.10, n.1, p.39-55, 1993a.

CLAVERO CEPEDA, T. Efecto de la desolación sobre el crecimiento, área foliar e intercepción de luz en pastos tropicales. Revista de Agronomía (LUZ), v.10, n.1, p.57-67, 1993b. 
COOPER, J.P. Physiological and morphological advances for forage improvement In. SMITH, J.A. and HAYS, V.W. (Ed INTERNATIONAL GRASLAND CONGRESS, 14, Lexington K.Y., 1981. Proceedings. Boulder CO.: Westview Press, 1983.

COOPER, J.P.; TAINTON, N.M. Light and temperature requirements for the growth of tropical and temperate grasses. Herbage Abstracts, v.38, p.167176, 1968.

CORRÊA, L. de A. Produção intensiva de carne a pasto. In: CONVENÇÃO NACIONAL DA RAÇA CANCHIM, 3, São Carlos. 1997. Anais São Carlos: EMBRAPA-CPPSE, 1997. p.99-105.

CORSI, M.; MARTHA JUNIOR, G.B. Manejo de pastagens para produção de carne e leite. In: PEIXOTO, A.M.; MOURA, J C. de.; FARIA, V.P. de. (eds). SIMPÓSIO SOBRE MANEJO DE PASTAGENS, 15, Piracicaba, 1998. Anais Piracicaba: FEALQ, 1998. p.55-84.

DAVIES, D.A.; FURTHERGILL, M.; MORGAN, C.T. Assessment of contrasting perennial ryegrasses and white clover under continuous stocking in the uplands. 5 - Herbage production, quality and intake in years 4-6. Grass and Forage Science, v.48, n.3, p.213-222, 1993. 
DA SILVA, S.C.; PEDREIRA, C.G.S. Princípios de ecologia aplicados ao manejo de pastagem. In: FAVORETTO, V.; RODRIGUES, L. R.A \& RODRIGUES, T.J.D. (eds.) SIMPÓSIO SOBRE ECOSSISTEMA DE PASTAGENS, 3, Jaboticabal, 1997. Anais. Jaboticabal: FCAV (UNESP)FUNEP, 1997. p1-62.

DA SILVA, S.C.;PASSANEZI, M.M.; CARNEVALLI, R.A.; PEDREIRA, C.G.S.; FAGUNDES, J.L. Bases para o estabelecimento do manejo de Cynodon spp. para pastejo e conservação. In: PEIXOTO, A.M.; MOURA, J C. de.; FARIA, V.P. de. (eds). SIMPÓSIO SOBRE MANEJO DE PASTAGENS, 15, Piracicaba, 1998. Anais Piracicaba: FEALQ, 1998. p.129-150.

DONALD, C.M.; BLACK. The significance of leaf area in pasture growth. Herbage Abstracts, v.28, p.1-6, 1958.

ESALQ. Departamento de Ciências Exatas http://www.ciagri.usp.br/ emdabreu/MEDIAS.txt (06 Jan. 1999)

GARDNER, F.P.; PEARCE, R.D.; MITCHELL, R.L. Physiology of crop plants. Iowa: Iowa State University Press, 1985. 327p.

GOMIDE, C.A. de M. Morfogênese e análise de crescimento de Panicum maximum (Jacq.) Viçosa, 1997. 53p. Dissertação (mestrado) - Universidade Federal de Viçosa.

GOMIDE, C.C.C. Algumas características fisiológicas e químicas de cinco cultivares de Cynodon. Jaboticabal, 1996 100p. Dissertação (mestrado) Faculdade de Ciências Agrárias e Veterinárias, Universidade Estadual Paulista "Júlio de Mesquita Filho". 
HARLAN, J.R. Cynodon species and their value for grazing and hay. Herbage Abstracts, v.4, n.3, p.233-238, 1970.

HARLAN, J.R.; WET, J.M.J. de. Sources of variation in Cynodon dactylon (L) Pers. Crop Science, v.9, p.774-778, 1969.

HARLAN, J.R.; WET, J.M.J. de; RAWAL, K.M. Origin and distribution of the Seleucidus race of Cynodon dactylon (L) Pers. Var. dactylon (Gramineae). Euphytica, v.19, p.465-469, 1970.

HARRIS, W. Defoliation as a determinant of the growth, persistence and composition of pasture. In: WILSON, J.R. (Ed.) Plant relations in pastures. CSIRO, East Melbourne, Australia, 1978. p.67-85.

HAY, R.K.M; WALKER, A.J. An introduction to the physiology of crop yield. Essex: Longman Scientific and Technical, 1989. 292p.

HODGSON, J. Grazing Management: Science into Practice. Longman Scientific and Technical , Logman Group ,U. K. , 1990. 203p.

HUMPHREYS, L.R. Pasture defoliation practice: A review. Journal of the Australian Institute of Agricultural Sciences, v.32, p.93-105, 1966a.

HUMPHREYS, L.R. Subtropical grass growth: II Effects of variation in leaf area index in the field. Queenland Journal of Agricultural and Animal Science, v.23, p.388-358, 1966b.

HUMPHREYS, L.R.; ROBINSON, A.R. Subtropical grass growth: I Relationship between carbohydrate and leaf area in growth. Queenland Journal of Agricultural and Animal Science, v.23, p.211, 1966. 
HUMPHREYS, L.R. Tropical pasture utilizations. Cambridge: Cambridge University Press, 1991. 206p.

JACQUES, A.V.A. Fisiologia do crescimento de plantas forrageiras (área foliar e reservas orgânicas) In. FARIA, V.P. de. \& MOURA, J.C. de.(Ed.). SIMPÓSIO SOBRE MANEJO DE PASTAGENS, 1, Piracicaba, 1973. Anais Piracicaba: FEALQ, 1973. p.95-101.

JEWISS, O.R.; WOLEDGE, J. The effect of age on the rate of apparent photosynthesis in leaves of tall fescue (Festuca arundinacea Schreb.). Annals of Botany, v.31, p.661-671,1967.

KEPHART, K.D.; BUXTON, D.R. \& TAYLOR, S.E. Growth of $\mathrm{C}_{3}$ and $\mathrm{C}_{4}$ perennial grasses under reduced irradiance. Crop Science, v.32, n.4, p.1033-1038, 1992.

KORTE, C.J.; SHEATH, G.W. Herbage dry matter production. The balance between growth and death. Proceedings of the New Zealand grassland association, v.40, p.152-161, 1979.

KORTE,C.J.; HARRIS, W. Effects of grazing and cutting In: SNAYDON, R.W. Ecosystems of the world: Managed grassland analytical studies. Amsterdam: Elsivier science publisher, 1987. P.71-79.

LAMELA, L.; PEREIRA, E.; SILVA, O. Evaluación comparativa de pastos para la producción de leche. I. Bermuda cruzada-1, bermuda callie y guinea $\mathrm{SIH}$ 127. Pastos y forrajes, v.7, p.395-404,1984.

LAWLOR; D.W. Photosynthesis, productivity and environment. Journal of Experimental Botany, v.46 (especial issue), p.1449-1461, 1995. 
LUDLOW, M.M. Light relations of pasture plants. In: WILSON, J.R. (Ed) Plant Relations in Pastures. CSIRO, East Melbourne, Australia, 1978, p.35-49.

MADAKADZE, I.C.; COULMAN, B.E.; PETERSON, P.; STEWART, K.A.; SAMSON, R.; SMITH, D.L. Leaf area development, light interception, and yield among switchgrass populations in a short-season area. Crop Science, v.38, p.827-834, 1998.

MILERA, M.; GARCIA-TRUJILLO, R., MENCHACA, M. Efecto de la carga y la estancia sobre la producción de leche en bermuda cruzada-1. II. Analises de los sistemas destacados con un nível medio de N. Pastos y Forrajes, v.11, p 165-170, 1988.

MISLEVY, P.; PATE, F.M. Establishment, management, and utilization of Cynodon grasses in Florida. In: ALVIM, M.J.; VILELA, D.; BRESSAN, M.; PASSOS, L.P.; BOTREL, M.A. (eds.) WORKSHOP SOBRE POTENCIAL FORRAGEIRO DO GÊNERO CYNODON, Juiz de Fora, 1996. Anais. Coronel Pacheco: CNPGL-EMBRAPA, 1996. p.127-138.

MISLEVY, P.; BROWN, W.F.; DUNAVIN, L.S.; JUDD, W.S.; KALMBACHER, R.S.; KUCHAREK, T.A.; NOLING, J.W.; RUELKE, C.; SONODA, R.M.; STANLEY, R.L. Jr. Florakirk Bermudagrass. Florida Agricultural Experiment Station, 1995. 9p. (Circular S-395).

MITIDIERI, J. Manual de gramíneas e leguminosas para pastos tropicais. São Paulo: Nobel, 1983. 198p. 
MOTT, G.O., POPENOE, H.L. Grasslands. In: ALVIM, P.T., KOZLOWSKI, T.T. (Ed.) Ecophysiology of tropical crops. New York: Academic Press, 1977. p.157-186.

NABINGER, C. Princípios da exploração intensiva de pastagens. In: PEIXOTO, A.M.; MOURA, J C. de.; FARIA, V.P. de. (eds). SIMPÓSIO SOBRE MANEJO DE PASTAGENS, 13, Piracicaba, 1996. Anais Piracicaba: FEALQ, 1997. p.15-96.

OMETTO,J.C. Registros e estimativas dos parâmetros metereológicos da região de Piracicaba, SPP. Piracicaba: FEALQ, 1989. 76p.

PARSONS, A.J. The effects of season and management on the growth of grass swards. In: JONES, M.B.; LAZENBY, A. The grass crop: The physiological basis of production. London: Chapman and Hall, 1988. p.129-177.

PEARCE, R.B.; BROWN, R.H.; BLASER, R.E. Photosynthesis in plant communities as influenced by leaf angle. Crop Science, v.7, p.321-324, 1967.

PEDREIRA, C.G.S. Avaliação de novas gramíneas do gênero Cynodon para a pecuária do sudeste dos Estados Unidos. In: ALVIM, M.J.; VILELA, D.; BRESSAN, M.; PASSOS, L.P.; BOTREL, M.A. (eds.) WORKSHOP SOBRE POTENCIAL FORRAGEIRO DO GÊNERO CYNODON, Juiz de Fora, 1996. Anais. Coronel Pacheco: CNPGL-EMBRAPA, 1996. p.111-125. 
PEDREIRA, C.G.S.; NUSSIO; L.G.; DA SILVA, S.C. Condições edafo-climáticas para produção de Cynodon spp. In: PEIXOTO, A.M.; MOURA, J C. de.; FARIA, V.P. de. (eds). SIMPÓSIO SOBRE MANEJO DE PASTAGENS, 15, Piracicaba, 1998. Anais Piracicaba: FEALQ, 1998. p.85-114.

RHODES, I. The relationship between productivity and some components of canopy structure in ryegrass (Lolium spp.). II. Yield, canopy structure, and light interception. Journal of Agricultural Science, v.77, p.283-292, 1971a.

RHODES, I. Productivity and canopy structure of two contrasting varieties of perennial ryegrass (Lolium perenne L.) grown in a controlled environment. Journal of the British Grassland Society, v.26, p. 9-15, 1971b.

RHODES, I. Relationship between canopy structure and productivity in herbage grasses and its implication for plant breeding. Herbage Abstracts, v.43, p.129-133, 1973.

SAS INSTITUTE. SAS user's guide: release. 6.03, Cary, 1988. 1028p.

SHAIN, S.S. The effect of quality and quantity of light on development of forage plants In: SKIDMORE, C. L.(Ed.) INTERNATIONAL GRASSLAND CONGRESS, 8, Berkshire England, 1960. Proceedings. Oxford: Alden Press,1961. p.41-44.

SHEEHY, J.E.; COOPER, J.P. Light interception, photosynthetic activity, and crop growth rate in canopies of six temperate forage grasses. Journal of Applied Ecology, v.10, p.239-250, 1973. 
SIDDIQUE, K.H.M.; BELFORD, R.K.; PERRY, M.W.; TENNANT, D. Growth, development and light interception of old and modern wheat cultivars in a mediterranean-type environment Australian Journal Agriculture Research, v.40, p.473-487, 1989.

SOLLENBERGER, L. E.; PEDREIRA, C.G.S.; MISLEVY, P.; ANDRADE, I.F. New Cynodon forages for the subtropics and tropics. In: INTERNACIONAL CONF. LIVESTOCK IN THE TROPICS, 1995, Gainesville. Proceedings Gainesville: University of Florida, 1995. p.22-26.

SZEICZ, G. Solar radiation in crop canopies. Journal of Applied Ecology, v.11, p.1117-1156, 1974.

TAINTON, N.M. A comparison of different pasture rotations. Proceedings of the New Zealand Grassland Association, v.35, p.204-210, 1974.

VILELA, D.; ALVIM, M.J. Produção de leite em pastagem de Cynodon dactylon (L.) Pers., cv. "Coast-cross". In: ALVIM, M.J.; VILELA, D.; BRESSAN, M.; PASSOS, L.P.; BOTREL, M.A. (eds.) WORKSHOP SOBRE POTENCIAL FORRAGEIRO DO GÊNERO CYNODON, Juiz de Fora, 1996. Anais. Coronel Pacheco: CNPGL-EMBRAPA, 1996. p.77-91.

WARD, C.V. ; BLASER, R.E. Carbohydrate food reserves and leaf area in regrowth of orchardgrass. Crop Science, v.1, p.366-370, 1961.

WARREN-WILSON, J. Analysis of the distribution of foliage area on light interception and pasture growth. In: IVINS, J.D. The measurement of grassland productivity. London: Butterworths, 1959. p.51-61. 
WARREN-WILSON, J. Influence of spatial arrangement of foliage area on light interception and pasture growth. In: INTERNATIONAL GRASSLAND CONGRESS, 8, 1960. Berkshire. Proceedings Oxford: Alden Press, 1961. p.275-279.

WATSON, D.J. Comparative physiological studies on the growth of field crops. I. Variation in net assimilation rate and leaf area between species and varieties and within and between years. Annals of Botany, v.11, p.41-76, 1947.

WATSON, D.J. The dependence of net assimilation on leaf area index. Annals of Botany, v.22, p.37-54, 1958.

WHATLEY, J.M.; WHATLEY, F.R. A luz e a vida das plantas. Trad. de G. M. Felipe. São Paulo: EDUSP, 1982. 101p.

WILSON, R.J.; MANNETJE, L. Senescence, digestibility and carboidrate content of Buffel grass and Green Panic leaves in swards. Australian Journal Agriculture Research, v.29, p.503-516, 1978.

YUNUSA, I.A.M.; SIDDIQUE, K.H.M.; BELFORD, R.K.; KARIMI, M.M. Effect of canopy structure on efficiency of radiation interception and use in spring wheat cultivars during pre-anthesis period in a mediterranean-type environment Field Crops Research, v.35, p.113-122, 1993. 